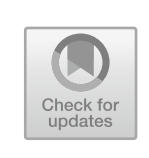

\title{
5
}

\section{Two Exogenous Crises in 1997 and 2008: Occurrence, Response and Impact}

In the mid and late 1990s, the Chinese government had adopted radical reforms in response to crises, effectively taking a further step of "retreat" from non-profitable small and medium state-owned enterprises through sell-offs. After that, Chinese economic growth went from a model that relied predominately on domestic demand and government investments, to one mainly dependent on overseas markets. International economic circumstances therefore began to have an increasing impact on China's economy. China was inevitably being incorporated into globalization dominated by transnational capital.

We refer to this process of China's absorption into globalization as "the $4^{\text {th }}$ wave of foreign capital introduction" over the 70 years of contemporary Chinese history.

The process manifested two key characteristics: first, foreign capital played an increasingly dominant role in the Chinese economy amidst the structural adjustment brought on by Chinese industrial capital's overseas expansion. Entering the twenty-first century, transnational companies almost completely controlled China's high value-added industries, taking most of the profit; second, China became the recipient of outward cost transfer from countries that dominated globalization. Hence the 
economic crises it had to deal with were also predominately exogenous. Faced with this kind of crises created by external factors, the Chinese government lacked the necessary rights to participate in international negotiations and in setting institutional arrangements. Domestic regulatory measures were generally far from effective. As a result, even before the "government retreat [from the economy]" reform was completed, there emerged the "government advance" reform.

These two were new characteristics of economic reform and development that were brought on by globalization, dominating China's direction in history. Although China had adopted three rounds of opening up in different forms in the past, their impact on the domestic and world economy was on a different scale compared to this 'opening up' in the new century after the country's integration into globalization. ${ }^{1}$

\section{Four Rounds of 'Foreign Capital Introductions' Over Sixty Years, Each Accompanied by Emergence of Two Crises}

During the 60 years from 1949 to 2009, China had experienced four rounds of foreign capital introduction. On each occasion, the contents as well as results were similar, involving the introduction of foreign equipment and technology, followed by two economic crises.

The first of such crises took place in the 1950s. During the ten years between 1950 and 1960, the USSR had first heavily invested and then abruptly halted the investment, thus leading first to an economic surge then a sharp decline, resulting in two deficit and unemployment crises in 1960 and 1968 respectively.

The second round happened in the 1970s, notably from 1972 to 1979. The high costs of Western equipment, technology and services as well as the debts incurred gave rise to two deficits and unemployment crises. These occurred in 1974-1976 and 1979-1981 respectively.

${ }^{1}$ Wen Tiejun et el: 解读苏南 (Interpreting South Suzhou). Suzhou University Press, 2011. 
The third round of "foreign capital introduction" into China took place in the 1980s, simultaneous with the central government's policy of conceding power and interest to local governments. Given the excessive debt repayment pressure the central government had to bear, local authorities were given the right to expand the scale of "opening up". That gave rise to the stagflation crisis of 1988-1989 as well as the economic crisis in 1993-1994 in which three simultaneous major deficits were accompanied by high inflation and high unemployment.

Although these six crises were closely related to "introducing foreign capital" or "opening up", the triggering key factors were mainly deficits in the fiscal budget, the current account and in the financial sector. Essentially they constituted an "endogenous crisis" in the economy.

Yet in the mid-1990s, under the effect of the reform that had urban and rural populations both bearing the costs of the crisis, as well as the effect of the subsequent decline in domestic demand, China had accelerated its pace into joining globalization. Consequently, the two crises that occurred in 1997-1998 and in 2008-2009 were related to external circumstances.

On this basis, we believe that the latter two crises were quite different from the previous six, and belonged to the "exogenous crisis" category, brought about by the "fourth round of foreign capital introduction", under the conditions of globalization.

China's fourth introduction of foreign capital took place in a situation in which the national economy was already under the determining impact of overseas demand and followed the trend of being taken up in global capitalization. Garnering the common points between the two exogenous crises, we can hardly find any dissimilarity.

First, the cause of the crisis. Before it happened, the domestic economy had to a large extent been driven by exports. As such when foreign financial crisis broke out, causing significant decline in export, domestic economic growth also suffered. Another outcome was increased unemployment.

Second, measures in response: In contrast to the austerity measures that the government had adopted in the past when endogenous crises occurred, the government undertook large-scale expansionary fiscal 
policy to increase investments and provide a stimulus for domestic demands, preventing a sharp decline in economic growth.

The biggest difference in the central government's measures in response to these two crises lay in higher investments after 2008 to the sannong, which was effectively an extension of the new policy supporting the sannong by the central government since 2003. Because of that, not only did capital and labor, two of the three essential factors of production, flow back to rural regions on a large scale, partially restoring the regulating function of the countryside as a 'labor pool', it also facilitated the construction of a 'second asset pool' in the county economy.

That may have been the most notable favorable experience out of the measures in response to the crisis of 2008-2009, with outcomes beneficial both to urban and rural sectors.

Yet, on the adverse side, the social contradiction that was of concern also became intensified alongside these bail-out measures. While the bail-out investment of 1997-1998, in which urban interests were the prime focus, did bring economic revival, it brought excessive institutional costs to the rural sector due to the excessive use of rural resources, to the extent that a large number of social conflicts arose. Coincidentally, in the even larger bailout investment of 2008-2010, that past approach of transferring the crisis to rural regions - appropriating scarce rural resources and accelerating resource capitalization-became even more blatant. Local governments around the country adopted pro-capital policies with little restraint. Therefore social conflicts, referred to as "mass incidents", increased sharply. The more vociferous the domestic and overseas opinions were, the more difficult "stability maintenance" became.

Very few have presented objective analyses integrating politics and economics to explain a confrontation like this, which is the outcome of institutional cost transfer as a response to crisis. Many scholars would do no more than echo ideologues overseas, taking such social conflicts as the ground for "political self-deprecation." For example, they would claim that these conflicts signal political or social failure. By doing so, these scholars have mostly benefited themselves. Without proper explanations it would not be possible to come up with solutions. Hence the kinds of contradictions accompanying bail out measures simply continued. The 
mass incidents spread and sharply increased year over year, so much so that even though the political direction of 'constructing a harmonious socialist society' was put forward in the fourth plenary of the 16th National Congress, formally mobilizing all positive factors for that purpose, local governments and authorities around the country that were already thoroughly corporatized simply dismissed it, and continued to give priority to cashing in land for attracting business and investments.

Since reform and opening up, the developmentalist outlook-the essence of which was to push forward the capitalization of resourcesmarched on and the allocation of institutional costs and gains became increasingly imbalanced. That constituted the biggest obstacle to carrying out the CPC's governing ideas of 'scientific development outlook', 'building a harmonious society' and 'ecological civilization'.

\section{The Eighth Crisis: Measures to Deal with 1997 Asian Financial Crisis and the Impact}

In the same year that financial storms erupted in various East Asian countries whose economies based mainly on manufacturing and trade, the CPC proposed in the 15th National Congress report (1997) to continue the development of various markets, focusing on markets for essential production factors including capital, labor and technology, as well as improving price formation mechanisms for these factors. Furthermore, the commercialization reform of state-owned banks and of the People's Insurance Company of China would be quickened, to enhance the policy-oriented financial system.

It was the first time that the $\mathrm{CPC}$, in its transition from a revolutionary party to governing party, clearly affirmed the status of "capital" in a political report of the National Congress, putting forward the notion of "capital (as production factor) market". 
On one side, although this official confirmation of capital came five years later than the actual opening of the capital market in 1992, it nevertheless implied that "capital" had already secured a sense of 'political correctness' in the ideology of Chinese economic system.

Yet we should not ignore the other side of this major institutional transition-the force of circumstances. In fact, no sooner had the Chinese leadership confirmed the status of "capital" than the East Asian Crisis occurred, demystifying the East Asia industrial expansion model that Chinese intellectuals held their belief in. It sounded the alarm for China's monopolized financial sector, where non-performing debts were mounting. Closely following that, just one month after the 15th National Congress, in the national financial working session the central government made the decision to launch marketization reform of stateowned financial institutions on all fronts, as a response to the challenge of the South-east Asian financial crisis. From then on, Chinese financial institutions went along the path of "securitization and market offering". Given their nature of pursuing liquidity for profit, they inevitably became alienated from the real economy over time, forming an independent interest bloc. Right after commercialization, they dived into the brave new world of mixing investment banking with general commercial banking, replicating Wall Street's "too big to fail" scale, in an attempt to join the global competition of financial capitalism.

\section{Change in Origin of the Crisis: Why Was It an "Imported" Crisis?}

China encountered an "imported (exogenous)" crisis in 1997-1998 and then economic depression in 1999-2001, which was signified by deflation. That was the outcome of two factors, first the macro-economic regulation that started in the second half of 1994 and cumulated in a "soft landing" in 1997, then the East Asian financial crisis in 1997, with the former being a prelude of the latter.

The central government's macro-regulation over three consecutive years from 1994 to 1997 had brought about the major structural 
change of declining domestic demand and rising dependence on oversea markets.

Even though the guiding principle of macro-regulation was introduced in 1993, it was not until 1996 that economic overheating, driven by the capital markets of stocks, futures and real estate was cooled down by economic and political measures, hence the declared "soft landing".

This could be reflected in fixed investment growth rate. Based on monthly statistics, it could be seen that in early 1996 the growth rate of fixed investment fell below $10 \%$ for the first time, with the rate for the full year falling below 20\%. In the first half of 1997 the investment growth rate was controlled and kept within $15 \%$, indicating that the macro-economy had generally passed the overheating phase. Based on annual statistics, the full year fixed investment growth rate during the 1993 peak was $61.8 \%$ while in 1997 it came down to $8.9 \%$, below $10 \%$ for the first time. The pull of investment on GDP was 11 percentage points in 1993 while the contribution rate was 78.6\%. In 1997 the figure dropped to $2.1 \%$ and $18.6 \%$ (Figs. 1 and 2 ).

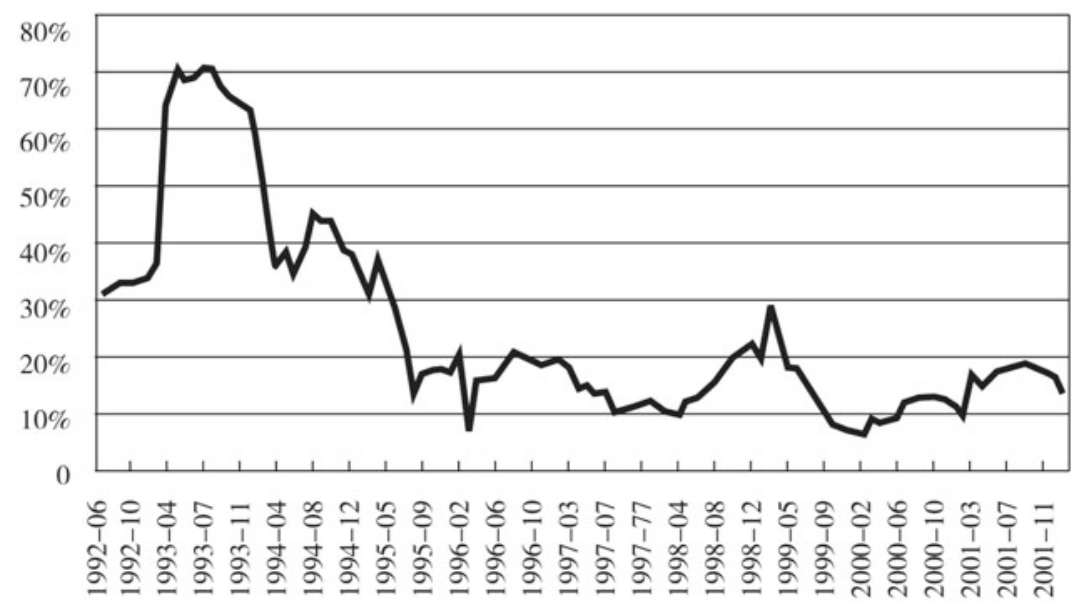

Fig. 1 Monthly fixed investment growth rate in China 1992-2001 (Data source: China Statistics Yearbook 2009) 


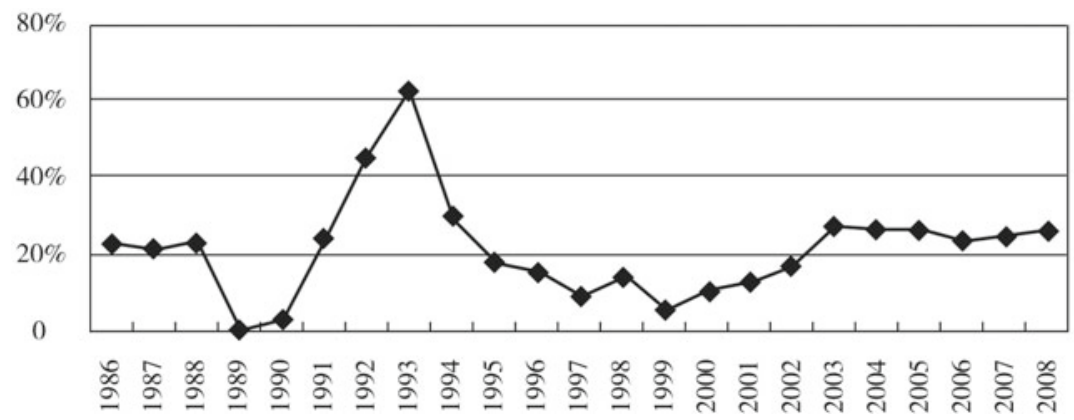

Fig. 2 Annual fixed investment growth rate in China 1986-2008 (Data source: China Statistics Yearbook 2009)

At the same time as the investment demand declined, export was growing year over year. Under the double stimulation of macroregulation and foreign exchange reform since 1994, export replaced investment to become the primary impetus to China's economic growth. "The net export of goods and services reached 99.85, 145.93 and 274.5 billion yuan in 1995, 1996 and 1997 respectively, higher than the preceding year by $57.5 \%, 46.1 \%$ and $88.1 \%$, and accounted for $1.68 \%$, $2.1 \%$ and 3.6\% of GDP". ${ }^{2}$ In 1997 when the East Asian financial crisis erupted, the pull rate of full year exports on the national economy was 4.2 percentage points, a contribution reaching $44.4 \%$. The pull rate of current year investment on economic growth was 34.3\%.

In other words, before China put forward a strategy to narrow the "three major gaps" (the rich and the poor, urban and rural, coastal regions and inland), and had there not been the large-scale diversion of excess industrial capital towards the international market, the domestic supply and demand would have been seriously unbalanced.

Unexpectedly, when mainstream Chinese academics were passionately talking about "the inevitable trend towards global unification through marketization and political liberation," closely following the "World Bank consensus" transition path prevalent in the 1990s, the East Asian crisis broke out abruptly in the second half of 1997 . The economic crisis

${ }^{2} \mathrm{Ma}$ Hong (马洪) \& Lu Baipu (陆百甫), 中国宏观经济政策报告 (China Macro-economic Policy Report). Beijing: China Fiscal and Economic Press, 1999. 
that it induced in China happened right at that essential moment of its historical transition, from bidding farewell to the age of scarcity to entering that of oversupply. China was then caught in a dilemma. The strategy just formed by the central government to foster globalization was struck by a sudden decline in overseas demand (Fig. 3).

With regard to "over production" in the general sense that classical Marxism had analyzed, not only were the Chinese economists at the time not aphasiac like contemporary Chinese economists are, they were able to point out its correlation to macro-regulation with Chinese characteristics. Experienced experts in the policy advisory section of the government had made assessment in 1998 that China started to move from an economy of scarcity to the phase of excess production capacity, which was in essence more in accord with other industrialized countries:

"From the perspective of the economic growth environment, externally there is the onslaught of the Southeast Asian financial crisis and domestically there have been severe disasters of flooding. From the perspective of economic development, (China) is situated at an important turning point, beginning to move into a new phase. The characteristic of scarcity is fading out and the characteristics of buyer's market are gradually showing up. The change in the overall relationship of supply and demand volumes as well as the structural contradictions that are exposed would exacerbate market competition and difficulties in businesses would stand

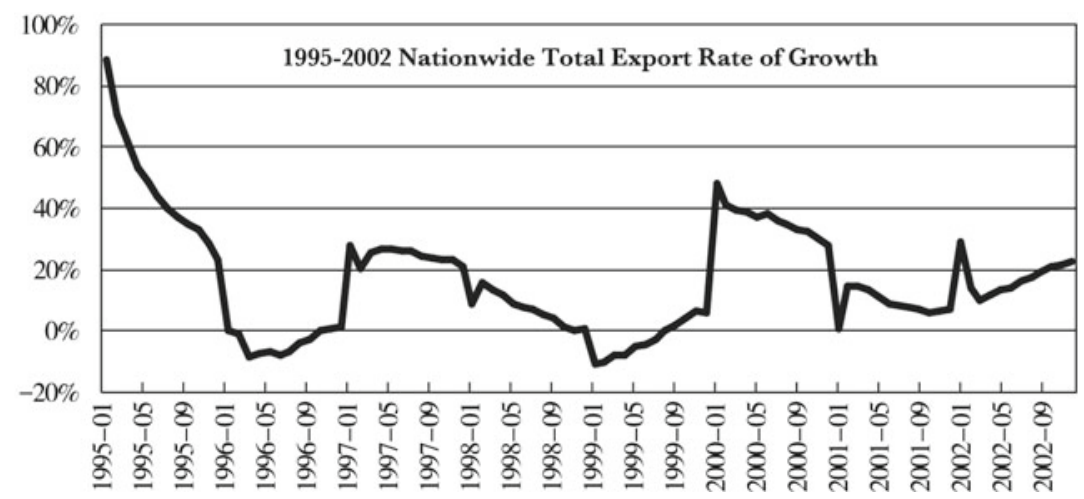

Fig. 3 Export trade monthly growth rate in China 1995-2002 
out. From the perspective of the economic cycle, the economic policies since 1993 to curb inflation have gradually lowered the demand growth rate. Economic growth will enter a relatively obvious self-contracting state as a result. The sum impact of the various factors above will make it unprecedentedly difficult to maintain stable economic growth in 1998 .

The change in the economic institution and development phase actually began in the mid-1990s. That they have not quickly appeared in the overall supply and demand capacity relationship is mainly because growth in net export had, to a certain extent, hidden the changes there ...... The growth in external demand has to some extent alleviated the domestic contradiction of higher supply than demand, hence diluting the changes in the economic model in that supply and demand capacity relationship aspect. The East Asian crisis that began in July 1997 had a major impact on China's export growth. The rate of export growth abruptly fell to $0.5 \%$ in 1998 . The rapid contraction of external demand is bound to reveal the change in supply and demand capacity relationship caused by changes in domestic economic model." 3

On this aspect, another influential economist in Chinese policy-making, Justin Yifu Lin, proposed unambiguously at the end of 1999 in an internal conference that to target the problem of overcapacity it would be essential to initiate the New Rural Construction investment strategy. He felt that the Chinese economy had already fallen into the "vicious cycle under the condition of a double excess". Although that strategic adjustment proposal was not adopted then, he persisted in raising it and ultimately in late 2001 it came within the scope of vision of central leadership. In 2005 it was affirmed to be the top priority in China's 11th Five-year Plan.

Actually, as early as in 1978 China's industrial goods export had already accounted for $45.2 \%$ of total exports. By 1997 the total export volume was US\$ 182.697 billion with industrial goods export totaling US\$ 158.767 billion, accounting for $86.9 \%$ of total exports. Out of the export goods, electrical goods had reached US\$ 59.32 billion, reaching

${ }^{3}$ Ibid. 
$32.5 \%$ of total export in that year, exceeding textile goods for three consecutive years to become the largest export goods category in China. ${ }^{4}$ It can be seen that even before the Reform and Opening Up, China had already transformed the structure of purely primary goods export in a period of thirty years. Then in less than twenty years after the Reform and Opening Up, the country completed industrial capital's domestic expansion and its adjustment on export structure.

And yet, this milestone change in the economic structure that happened at the end of the twentieth century would inevitably make Chinese economy more vulnerable to external economic volatility. In particular, ever since the West entered into the stage of financial capitalism, it has introduced measures to deepen financialization in developing countries. This has had a great impact on China.

From the perspective of changes in the international politicaleconomic order, after Nixon announced in 1971 the abrogation of the USD gold standard, and in 1973 adopted the monetary policy of a "floating exchange rate", European countries and America had resolved in the Brussels conference to follow the approach of increasing the net capital flow rate to sustain real consumption. The relocation of industrial production outwards and the inflow of capital gains induced a fundamental transformation in the nature and characteristics of crises happening in the West, different from those that previously took place during the phase of industrial capitalism. The outcome was that the exploitation of developing countries by Europe and America far exceeded that occurring in the 1950-1960s.

Furthermore, under the "free market" mechanism of complete opening up, developing countries entering the industrialization phase but facing severe capital scarcity accelerated the inflows of foreign capital, which sought to capitalize and take ownership of these countries' resources. And the financial capital that aimed to make quick profits by market liquidity was the least constrained by national frontiers. Once those financial investments made profits, they could escape anytime.

${ }^{4} \mathrm{Li}$ Jingzhi (李景治) \& Pu Guoliang (蒲国良), 社会主义建设理论与实践 (Theory and Practice of Socialism Construction). Beijing: China Renmin University Press, 2003. 
Like Northeast and Southeast Asia before them, the disintegrated Soviet Union, Eastern Europe as well as China that was expanding its industrial capital, were one after another absorbed into the Western monetary system In the 1990s. This was in fact a system sick to the core with inflationary bubbles. Then in accordance with the pattern, a whole series of changes were brought about by the inflows and outflows of foreign capital.

We may take a look at the impact of crisis on China's export structure. Before the 1997 crisis, export growth had an obvious effect in pulling up China's economy. Part of that effect also included the devaluation of Renminbi in 1994 and 1995, giving rise to sharp export growth, which then slowed down in 1996. The annual export growth was $31.9 \%$ in 1994 and $22.9 \%$ in 1995 while only $1.5 \%$ in 1996 . In 1997 it had revived to $20.9 \%$. The form of trade had also seen significant changes. In January 1995, the growth in general trade was $98.1 \%$, higher than total export growth in the same period by almost 10 percentage points. However, from the second half of 1995 onward, growth in general trade export rapidly fell behind total growth and declined in the overall proportion. In all of 1995 , general trade export growth was $15.9 \%$, lower than that of total export by 7 percentage points. In 1996 it fell down to $11.9 \%$, and the gap with total export growth widened to 13.4 percentage points. In 1997 the growth in general trade was higher than total by 3.2 percentage points. In 1998, with the impact of the Asian financial crisis, growth in export fell on all fronts rapidly and the full year total growth was only $0.5 \%$. From the perspective of ownership, state-owned enterprises' general exports recorded lower growth, well behind the overall growth rate. Enterprises under collectives had notably higher growth in general export than the rest of the country. From 1996 onward, general trade export by foreign enterprises were on the rise notably. As a whole, China's export as an impetus on economic growth fell from 4.2 percentage points in 1997 to 1.3 percentage points in 1998 .

In a nutshell, given the trend of modest investment growth as a result of macro-regulation, the decline in overseas demand directly led to a domestic economic crisis characterized by depression and deflation. 


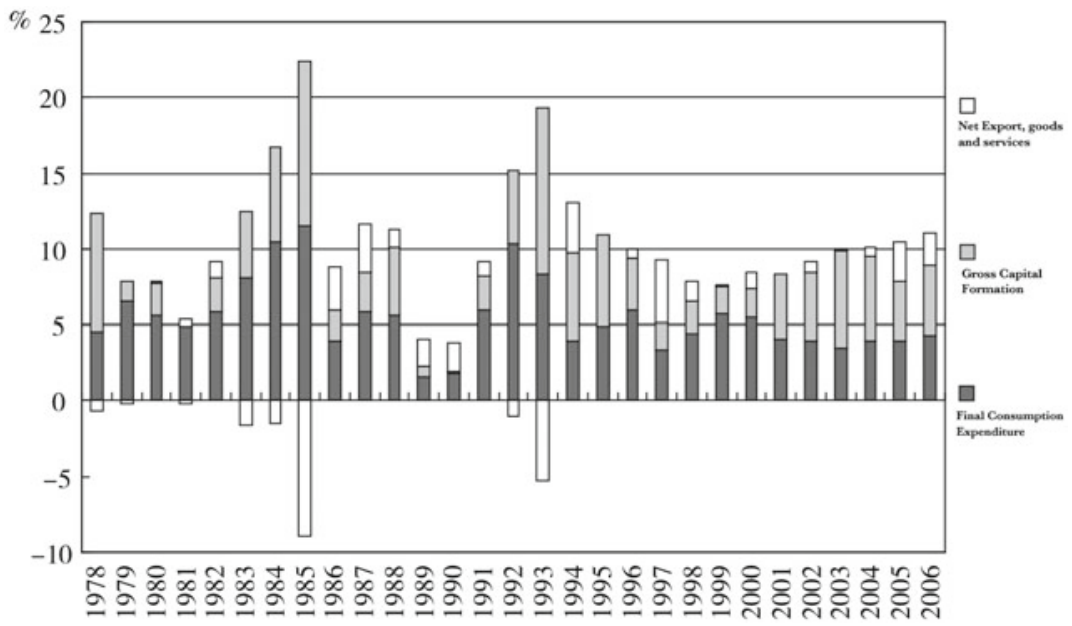

Fig. 4 Volatility and key drivers for China's macro-economic growth, 1978-2006

If in 1994 the key word that would send a chill down people' spine was "inflation"-the price index up to $24.1 \%$ - then in the five years 1998-2002 with the impact of the Asian financial crisis the key word that would describe China's macro-economic trend changed in a quiet manner to one that common folks could no longer understand: "deflation" (Fig. 4).

"From October 1997 to December 1998, the price index recorded decline in absolute number for 15 consecutive months. That is a phenomenon that has never happened since the Reform and Opening Up. The change in price level index is an important reflection of the change in supply and demand relationship of goods and services. To a certain extent it reflects the level of development of the supply-morethan-demand relationship pattern"5 (Fig. 5).

After the official Chinese media announced in 1997 that the national economy had accomplished a "soft landing", it should have resumed a period of modest growth. Yet with the onslaught of the East Asian financial crisis, exports were severely affected. The entire Chinese economy

\footnotetext{
${ }^{5} \mathrm{Ma}$ Hong \& Lu Baipu, China Macro-Economic Policy Report. Beijing: China Fiscal and Economic Press, 1999.
} 


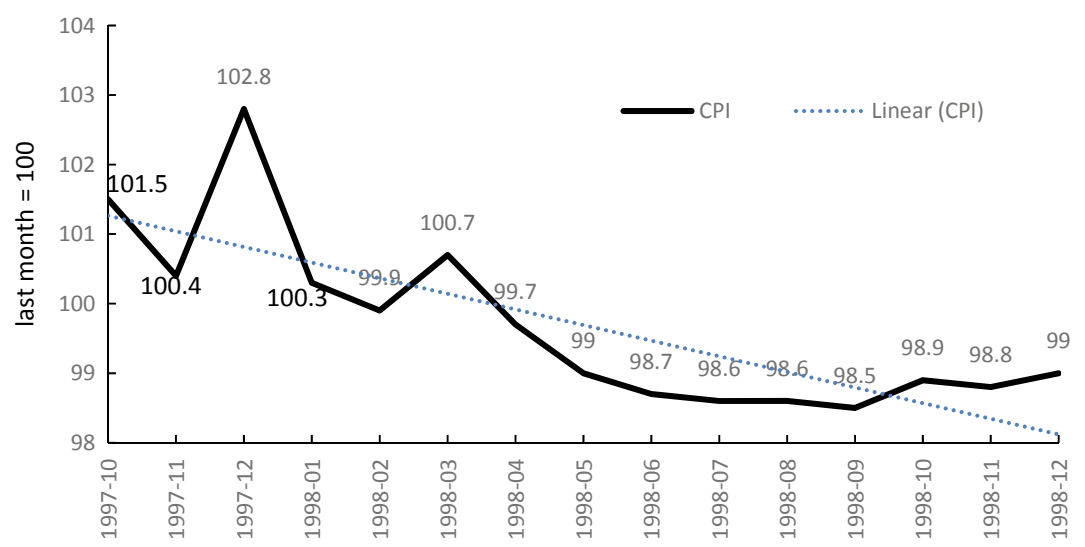

Fig. 5 Monthly CPI in China 1997 (October)-1998 (Data source: China National Bureau of Statistics website)

that was overly reliant on exports was hit hard. Therefore, the economic depression in China towards the end of the 1990s as characterized by deflation was an "imported" crisis brought on by the East Asian financial crisis.

\section{China's Key Experience in Responding to Imported Crisis: "Government Intervention"}

Facing that typical imported crisis brought on by the external financial storm, the central government's measures were mainly applied in the areas below: first, reforming the financial sector with resolve to prevent risks; second, issuing public debts on a large scale to invest in infrastructure construction and to expand domestic demand; third, simultaneously launching industrialization reforms in various sectors such as housing, education and health to spur on the growth of market consumption of domestic public goods through deepened monetization. Further, the central government raised the tax rebate rates on export to strengthen the price advantage of Chinese goods in the international market.

Although these measures entailed extremely high social costs, they did prevent the economy from a downward slide. In relation to the policy 
target for GDP, simplified as slogan of "ensuring 7, striving for 8," the measures were indeed effective.

\section{Financial System Reform-Financial Capital Controlled by Central Government Transformed into Monopolistic Capital Independent of Localized Real Industry}

One might say that it was only in 1992 when the government abandoned the coupon system that Chinese people used paper currency entirely for trades in the market. It signaled the start of monetization of the Chinese economy on all fronts. By 2002, the Chinese were able to complete the market reforms of finance, separating banking from the fiscal sector so that banks would no longer be subordinate to the latter. It signified the fact that from then onwards China had commercial banks that operated independently.

The East Asian financial crisis brought the issue of financial security to the attention of countries around the world. Under increasing pressure of bad debts in the domestic financial sector and with the financial crisis on the brink of eruption, the central government convened in November 1997 the National Financial Working Meeting. After that, the marketization reform of state-owned financial institutions was initiated in 1998 on all fronts, eventually making it possible for China's banking sector to develop into a relatively independent capital bloc, the most profitable one indeed.

Before the commercialization reform of banking in 1998, the fiscal and financial sectors were both used by the government as functional bodies to regulate the economy. During the transformation of China's modern financial system, the roles for each sector had undergone many major changes, in step with the progress of China's industrialization.

Generally speaking, in the first forty years of socialist China, fiscal measures played a more obviously dominant role in resources allocation. While the Renminbi was China's legal currency, and given that people's individual consumptions were largely rationed by the coupon system, money functioned mostly as a value measure of allocated goods, not circulated as an independent means of payment. That was the reason 
why before and in the early stage of the Reform, when consumable goods were in extreme scarcity, China was still able to avoid the hyper-inflation that many developing countries generally suffered.

On that basis we could say that the deepening of monetization in China's economy and the general monetization of Chinese society, had its beginning in the 1980s in step with the Reform, adopting the approach of "shrugging off burden" from the fiscal budget, then launched on all fronts in the year 1992 when the government completely abolished the coupon system.

Looking back at China's modern financial history, during the tenyear "golden" era that started in 1920s in the Republic era and ended in 1937, the annual average national economy growth rate between 1928 and 1936 had been as high as $8.4 \% .^{6}$ However, it had ultimately crumbled due to the "silver crisis" which was exogenous, as discussed in Chapter 1. The West had to abandon the Gold Standard due to the 1929-1933 Great Depression; further the U.S. propped up the silver price under domestic political pressure. These two factors led to the drainage of China's silver, in turn the collapse of the Silver Standard that had been in place for more than 400 years. The Republic government was faced with serious deflation due to substantial outflow of silver and in 1935 made the change to a fiat money system. At the beginning it was sustainable but soon after, with invasion by imperialist Japan first into Northern China in 1935 then all out in 1937, the supply shortage due to the war led to continuous high deficits and inflation. Ultimately, the U.S. stopped their aids in 1948, with the outcome of total collapse of the Republic's fiscal and financial systems. The Kuomintang regime was ousted in the revolutionary war.

Compared to the ill consequence that the Republic had suffered in abandoning the Silver Standard and fiat-monetization for 14 years which ultimately failed, the monetization that started in China in the 1980s in company with marketization had for the first time in contemporary history successfully established a financial system with paper money as the principal exchange medium.

${ }^{6}$ Sun Jian (孙健), 中国经济通史.中卷 (General Economic History of China second volume). China Renmin University Press, 2000-2001. 
Before the reform, because of Soviet Union's abrupt termination of strategic economic aids in 1958, China was forced to initiate localized industrialization supported by investments mostly from local government fiscal revenues (see Chapter 2). That had given rise to the division of power between the central and local governments over the fiscal and finance sectors, as well as the "Great Leap Forward" driven by local investments. Being in the hands of local governments, the "Great Leap Forward" had little restraint, and the expansions were too ambitious to be suppressed. By 1960 the accumulated fiscal deficit became too high, which then detonated an all-out economic crisis.

Similar to the localized industrialization in 1958, in early 1980 s with the fiscal system being decentralized to localized Contract Responsibility System, as well as the reform of banks to convert funding to stateowned enterprises "from fiscal allocations to loans," and adding to these the diversified vested interests among governmental bodies, the tens of thousands of local governments-controlled fiscal and financial systems had ignited a new round of rough, uncoordinated expansion. That was the substance of China's entrance into high growth mode by means of localized industrialization.

Within a short span of less than 20 years, China rapidly entered into the phase of overcapacity, which caught people by surprise. In particular, beginning with the accelerated development of speculative capital markets in early 1990s, the Chinese people, who had been inured to the government slogans of "fight for export, fight for foreign reserves" ringing in their ears as they woke up from the nightmare of extreme capital scarcity, were quickly finding themselves in a situation of excess industrial capital.

\section{Box 1: Chinese Financial Capital in Modern History-Formation and Expansion}

Whether in China or other countries, fiscal crises often become the juncture for innovation of the financial institutions. Yet the Chinese road of development of modern finance is not the same as that in the West. 
Even if in Sung and Ming dynasties China was able to take in an enormous quantity of precious metals from the West through overseas trade and, hence, alleviated the scarcity of currency, financial capital integrated with state credit had yet to take shape. The main reason had been that the formation of the state and the formation of capital did not take place in the same historical period, thus the power structure and relationship between them was fundamentally different from that in the West. Private capital had never become an independent agent that the ruling power could rely on. On the contrary, since the state had matured earlier than financial capital, when the monarchical system collapsed and China was passively absorbed into the world economy since Late Qing, the accumulation and expansion of industrial capital had more readily become dominated by bureaucratic capital and state capital. In this process, the bureaucratic capital found it easier to transform into national finance that held monopolistic status as compared to private finance. It had reached a peak for the first time during Chiang Kai Shek's rule, at which time domestic fiscal and financial systems mainly relied on American aid for support.

Since the late 1990s, China's finance became more concentrated and monopolistic. Later on, the Chinese banking sector replicated the Western financial system on all fronts. Combined directly with the state apparatus it was further integrated in the global financial regime, in the global competition dominated by financial capital.

Historically, it appeared inevitable that the state and bureaucratic capital instead of private capital played a dominant role in the century of modernization in China.

Source: Quoted from Liu Haiying's doctoral thesis, Chinese Renmin University.

The decentralization of power and concession of interests to local governments in the 1980s had given rise to subsequent reform involving the division of fiscal and financial systems as well as the uncoordinated expansion of localized industrialization. Yet very few people mentioned the biggest externality resulting from the Reform: given the need to secure the centralized political system, the central government was obligated to bear the debt responsibility that arose from the endeavors 
of local governments and enterprises (mostly state-owned) bringing in capital. That power division reform with its delineation of rights, obligations and interests would inevitably further complicate the relationship between the central and local governments.

It is obvious that financial reform was of paramount importance and relevant to the state political system.

To the central government, fiscal deficits would directly or indirectly become bank overdrafts although in 1993 it was announced that fiscal budget could no longer be overdrawn from the central bank. Under the pressure of deficits the central bank would increase money supply to purchase national debts, which was no more than shifting debts between pockets and bound to giving rise to mild or serious inflation. Since the Chinese fiscal and financial systems could still be regarded as an alternative form of state capitalism, the credibility of Renminbi during this period was still derived from "institutional credit" rather than "commercial credit". Fiscal and financial institutions were not separable in function in the Chinese economic system before the early 1990s. As long as there was no subversive political crisis and the government stayed intact, the state-owned banks would not need to secure ample capital funds as required in Western private capital financial system. Not only were the non-performing debts in banking sector underwritten by the central government using foreign reserves from the treasury, even the serious differential between deposit and loan that had emerged in the entire banking system was ultimately guaranteed by state credit and settled with increased issuance of money as the last-resort repayment.

Besides, given that the power division reform had been started by the central government in the attempt to shrug off its fiscal burden to local governments, the local fiscal and financial deficits would eventually have to be borne entirely by the central government nominally centralizing power in its hands. Thereupon that particular system gave rise to another aspect of government corporatization under the condition of a monopolistic economy: high speed expansion of state financial capital, the rights and obligations of which could not possibly be synchronized. ${ }^{7}$

\footnotetext{
${ }^{7}$ Wen Tie-jun \& Ji Han (计晗), 'Risk Borne by the Central Government and Competition among Local Governments'.
} 
After the fiscal system reform in the 1980s (since then local governments have had their own fiscal systems and budgets), local financial systems gradually became the main tool for accumulation and expansion of local resource capitalization driven by the corporatized local governments. Thereupon multi levels of banking systems and financial institutions took shape in China. Spurred on by local governmentcontrolled funds, all kinds of localized banks and financial institutions flourished. For example, the setting up of Mercantile Bank, Shenzhen Development Bank, Guangdong Development Bank, Fujian Industrial Bank and Hainan Development Bank was for the purpose of motivating economic development in coastal provinces and special zones. The setting up of Shanghai Pudong Development Bank was for driving economic development in Pudong. The Huaxa Bank was a product of the Shougang Group comprehensive reform pilot scheme. Various trust companies also became financing channels for local regions. With these, local governments and departments could usually avoid policy intervention by the central government, getting around the objective of controlling the scale of credit loans.

The economist Fan Gang pointed out: "Local governments' impulse and actions to control financial resources, i.e. funds, have effectively resulted in local financial institutions being subordinated to local governments. It was through this channel that the government's power became integrated with the market." 8 The on-going deposit and loan differentials in banks around the country had continued to strengthen local real economies. The more a local government and enterprises dared to make use of the externality of this system to create high leverage, the faster the economy would grow! One could randomly select cases for analysis from the "good models" of the 1980-1990s, regardless of the ideologies in which they were packaged, and discover similar factors. It may be seen as the outcome of the continuous deepening of the power division reform since 1979 between the central and the local over fiscal and financial systems, which intrinsically characterized by the effort of shrugging off fiscal burden from top down. It was also the institutional gain brought

${ }^{8}$ Quoted from: Liu Haiying (刘海英), “话说金融“故”事 (Old Stories of Finance)', 中国改革( 综合版) (China Reform (General)), 2003(3). 
about by the 1984 policy of "contract responsibility by tier", and the 1994 policy of "tax division system".

Nevertheless, since the various "good models" under ideological packaging were all "politically correct", very few people realized that the agents which took the most of the institutional gains and those who bore the most of the institutional cost were not the same. The success and failure of such reforms did not depend merely on who took most of the gain but, more importantly, on how vested interest groups that reaped the benefits could successfully transfer the costs to others.

If one would stand on this base to analyze the misalignment and disorder among various levels of the Chinese bureaucracy, a clear view would instantly open up. The biggest chunk of institutional costs from back then was the non-performing bank loans that were ultimately settled by the central government. It was the aftermath of the speculative bubble emerging since 1992, as well as a large number of unfinished real estate development projects due to illegal 'land grabbing craze' between 1993 and 1996 by local governments attempting to generate revenues from land. They later became bad debts within the banking sector under regulation and austerity by the central government. Yet those responsible for these "good models" were either being promoted to higher positions or got rich fast. The end result was simply that the central government had to settle the bad debts, and then in the name of various reforms transfer the costs to society.

Given the contradiction in the relationship between the central and the local that continued to defy alignment, two things occurred. First, the local financial sector, under the local government corporatism system, participated in local primitive accumulation and the coarse expansion of industrial capital, would often go hand in hand with industrial capital in times that were good but not when bad. The sunk cost became too much to retrieve, hence snow-balling into non-performing debts. It would indeed be unrealistic to expect the local financial sector to resolve them by itself. Second, along with the rising extent of monetization in the Chinese economy as well as the mounting deposit and loan differential within the financial sector since the mid-1990s, the banking sector controlled more and more resources and gradually replaced the 
fiscal sector to become one of the most important resource allocation institutions of the central government (Fig. 6).

It can be seen that the enormous non-performing debts in local banks had become a non-transferrable institutional cost of the financial sector, which then in turn forced the central government to launch

Red line - deposit loan differential Blue line - fiscal deficit Unit - Hundred Million Yuan

a. $1952-1979$

Fiscal Deficit and Deposit-Loan Differential in Financial Institutions 1952-1979

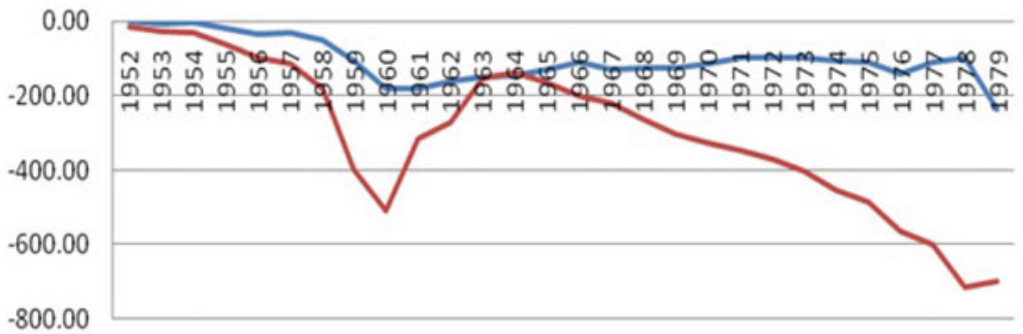

Fiscal Deficits (100 million $\mathrm{Rmb})$

Deposit-Loan Differential in Financial Institutions (100 million Rmb)

b. $\quad 1980-1999$

Fiscal Deficit and Deposit-Loan Differential in Financial Institutions 1980-1999

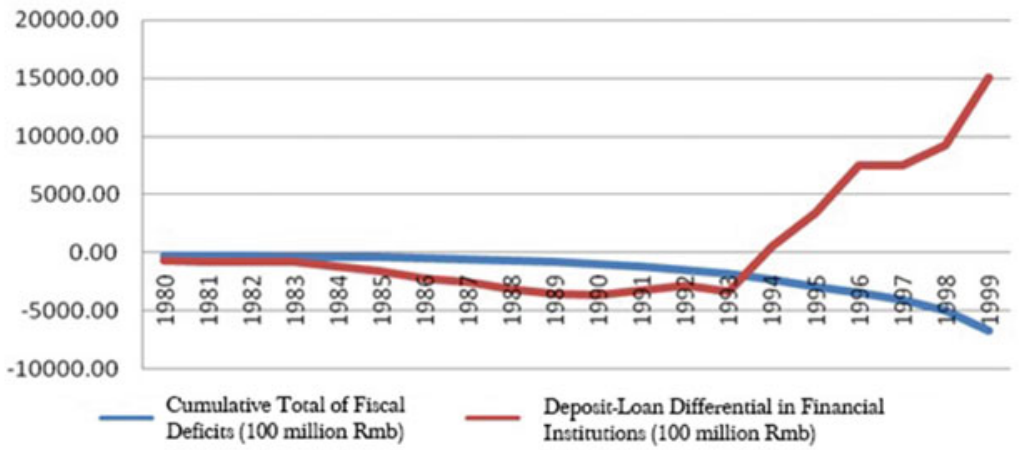

Fig. 6 Changes in China's fiscal deficits and deposit/Loan differentials in financial institutions 1952-2006 
c. $1994-2006$ (1994-1999 overlapped with fig. 4.6 b but at different scale )

Fiscal Deficit and Deposit-Loan Differential in Financial Institutions 1994-2006

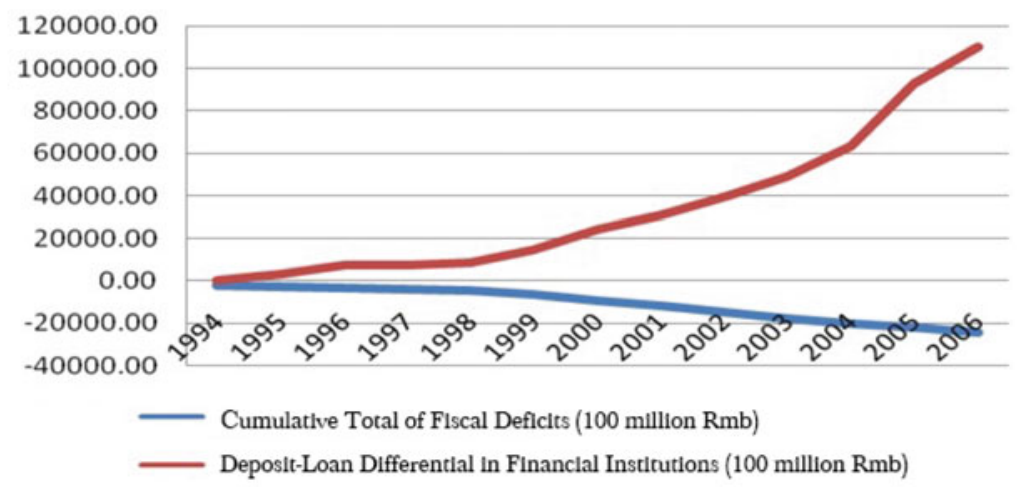

Fig. 6 (continued)

the Banking Commercialization Reform-a further step of 'burdenshirking', this time by the financial sector, after the comprehensive Tax Division Reform in mid 1990s absolving fiscal burden.

\section{Banking Commercialization Reform}

In 1995, the "Commercial Banking Law" was put forward with which state-owned banks were officially named as wholly-state-owned commercial banks, providing a legal basis for the banks to peel off their non-performing debts in the name of "commercialization".

The East Asia financial crisis in 1997 provided an opportunity for the central government to peel off that institutional risk. The crisis made the state realize the risk of the high number of non-performing debts in the banking sector. Thereupon a national financial working meeting was convened in November. The target was to strive, over a three-year period, to build a system of financial institutions, financial markets as well as monitoring and regulatory institutions that would suit the development of the socialist market economy. 
As the proportion of non-performing debts in banking sector after the 1997 East Asian crisis had been too high, the central government launched in 1998 an urgent marketization reform of the statemonopolized banking industry. Yet given the dominant authority over banks in the hands of the central government, the situation bifurcated at two levels. The reliance on external financial market was mainly found at the state level, while at local and regional level the Opening Up mostly resulted in dependency on foreign capitals and oversea markets. This outcome was perhaps not an exception to the "law of financial exclusion" that global financialization would generally show, with polarization as a rule. As a consequence, on the one hand, excessive liquidity appeared in the monopolized financial sector controlled by the central government, manifested at the surface as deposits and loans differentials and in substance the alienation of financial capital from industrial capital; on the other, in industrial sector local governments relied on for tax revenues and in agricultural sector peasants relied on for survival there was generally deficiency of liquidity, manifested as difficulties in obtaining loans.

At that time, the People Bank of China provided a refinancing of 20 billion yuan to different provinces, and undertook strict rectification on various investment trusts. These were mostly private as well as city credit unions and rural cooperative funds below county level, which were popular among the grass roots. This was done in order to sever the encumbrances that these local organizations might create on the state-owned financial system.

Nevertheless, given that the banking commercialization reform involved many complicated processes, there had indeed been many undesirable outcomes. One of the significantly representative cases was the 1998 Grain System Reform that had given rise to much discussion. The central government attempted to adopt a coordinated reform approach that would integrate closely with 'food finance', to have the society pay the bills for the food system as well as for its capital cost. However, it was not successful. 


\section{Box 2: “1998 Grain System Reform” for Facilitating Bank of Agri- culture Reform}

In order to relieve the financial burden of the Bank of Agriculture which had the highest proportion of non-performing loans among the stateowned banks, the central government had launched a reform in 1998 that anchored staple grain purchase and distribution directly with agricultural finance. The idea was to clarify and separate the obligation and operation in the system. Grain enterprises were separated from the governments. The responsibilities of the central and local governments were clarified and separated. Grain reserve and business operations were divided into two systems. Old and new financial accounts were also separated. Finally the grain price mechanism would be improved. The State Council further issued a supplementary memorandum on improving grain purchase and distribution, as well as price management, emphasizing that the key to implementing the grain distribution system reform was resolute execution of three policies, namely, 'open purchase', 'selling at above cost price' and 'purchase funds operating in the closed system'. The goal was to speed up state-owned food enterprises reform and raise competitiveness. The core was comprised of the three polices-using the government's traditional approach of nationwide unified purchase of grain to ensure bank's funds would be secured within a 'closed operation' with 'selling at above cost price'. In addition, it was hoped that selling grain at above cost price to the society would cover the costs of grain distribution system and bank capital providing loans.

The policy design of this reform was logically correct. However, the transaction cost between the government and the widely scattered peasants had been too high. So was the cost of the relevant execution systems around the country, which had already completed marketization (including privatization of most ground level shops). Ultimately, not only did it fail, it had added further to fiscal subsidies and unsettled account.

On another front, the central government had injected 270 billion yuan to the four major state-owned banks to complement their capital funds, while simultaneously set up four asset management companies (as well as the China Development Bank) to peel off the 1.3 trillion nonperforming loans from them. Finally the big four were pulled out of the quagmire of bad debts and washed clean by central government's fiscal budget. 


\section{Box 3: State-owned Bank Commercialization Reform}

During the local industrialization that began in China in the 1980s, ${ }^{*}$ local governments held the power to appoint, dismiss and manage personnel in state-owned banks around the country. The drawback of such decentralized management was that local government could directly intervene in bank investment decisions, making it hard for the banks to ensure the viability of specific investment projects. Many projects were launched simply in attempts to follow the trend. Once these projects failed they incurred non-performing loans in banks. That is to say, the state-owned banks had become the sites where risks of local industrialization would concentrate. That risk could hardly be handled by the bank's reserve.**

Therefore, when the central government initiated mandatory institutional transition - the commercialization of banking - in face of the enormous risks brought on by the 1997 financial crisis, the huge nonperforming debts that the state had to bear were in fact the results of the institutional cost of industrialization that state-owned banks had carried for local governments.

At that time, the proportion of non-performing assets in China's banking sector had far exceeded the counterpart in the Southeast Asian countries before the eve of 1997 crisis_in Malaysian commercial banks the non-performing asset proportion was $6.4 \%$, in Thailand $7.9 \%$ and even in Indonesia where the proportion was the highest it was merely $17 \% .^{* * *}$ Yet at end of 2000, China's state-wholly-owned banks had non-performing loans reaching $29.18 \%$ of total loans. Although the proportion had declined in 2001, it was still high at $25.37 \%$.

And because of that, the disposition of non-performing assets became the top priority in the institutional reform of the banking industry. At the end of 1997 a national financial working meeting was convened. In 1998 a special issuance of national debt amounting to 270 billion yuan was made to supplement state-owned banks capital fund. At the same time the loans were classified. In 1999, four financial asset management enterprises CINDA, Great Wall, Oriental and Huarong, corresponding respectively to Construction Bank, Agricultural Bank, Bank of China as well as Industrial and Commercial Bank, were set up to acquire and dispose of each bank's non-performing assets, thereby segregating the bad assets from the big four. 
In 2002, a swift handling of non-performing assets had taken place. According to the request of People's Bank of China the four major stateowned banks had to lower their non-performing asset rate to $15 \%$ before 2005 , which meant $3-5$ percentage points every year. It was not an easy task. In the first half of the year, the Bank of China had recovered cash of 15.7 Billion Yuan through auctioning, reducing the non-performing rate by 2.28 percentage points. According to statistics provided by the central bank, by the end of 2002 total loans in the four state-wholly-owned banks had amounted to 7 trillion yuan, out of which 1.7656 trillion was non-performing, a proportion of $25.37 \%$. Of this, more than 600 billion yuan was actual loss. And these numbers were after 1.4 trillion yuan of bad assets**** had been already taken out and handled to the four asset management companies.

Notes:

*Wen Tiejun, "Hundred Year in China-Four Twists and Turns", Dushu, 2001 (3); Wen Tiejun et el., 'Special Topic Report 2: From "Central Government Corporatism" to "Local Government Corporatism", in Interpreting Southern Suzhou, Suzhou University Press, 2011.

**Roland (1998) believed that before government functions realize successful transition, the fiscal system of local governments usually lacks the capacity to act in the role of supporting body to stateowned enterprises' soft budget-constraint. Further local governments would not have sufficient ability to provide construction funding to supplement local infrastructures and public services that were seriously lacking during the era of planned economy. Ba Shusong (2005) believed that in the aspect of local governance and banking reform, local governments had, during different stages of their own reforms, started out from their own self-interests and made use of system flaws in the banking reform to fight for financial resources, continuously changing the ways in doing so. From direct administrative intervention to exerting influence over banking policies, there had been profound impact on the effective transmission of monetary policy and the operation of micro financial agents. Reference: Liu Mou Yi Yang, 'Commercialization Reform of State-owned Banks and Future Trends,' Master Thesis, University of International Business and Economics, May 2012. http://www.doc88.com/p-4827071198102.html. 
*Wang Liya, 'Reflections On State-owned Commercial Bank Reform Model,' Finance and Insurance, 2001 (11). ****Zhang Jie, Analysis of China's State-owned Financial System Transformation. Economic Science Press, 1998.

***** Source of information: Xu Tao, 'Studies on China's State-owned Banks Commercialization Reform', Master Thesis, Liaoning Normal University.

If the financial supports from the Central Bank and the Ministry of Finance were added together, since 1998 the state had invested 2.9 trillion yuan in total on state-owned banks reform. Overall, between 1998 and 2005 , to maintain financial stability around 3.24 trillion yuan had been invested to support financial enterprises reform and alleviate financial risks. And the fiscal revenue of China in 2004 was only 2.63 trillion yuan. Even after that there had been further follow-up investments from the state. ${ }^{\text {? }}$

In this regard, the ratio of debt stock in China's financial system relative to fiscal revenue had exceeded $120 \%$.

If one looks at this process simply from a theoretical perspective, it would amount to an embedded transaction in institutional transition: the central government had made use of the state's economic sovereignty in the realms of national debt and money to pay for part of the institutional costs of transition. In this transaction of power division reform, the central government paid the quantifiable part of the accumulated costs incurred in local primitive accumulation for industrialization. At the same time it enjoyed the institutional gain. The central government took control of the financial capital profiting from monetization, which in turn took the opportunity to transform into a mega monopolistic financial conglomerate that was alienated from local industrial capital.

By 2002, the monopolistic state-owned financial capital that had different interests and visions from local governments and industrial capital was finally able to free itself from the intricacy with the latter,

\footnotetext{
${ }^{9}$ Financial Stability Analysis Group of the People’s Bank of China, 中国金融稳定报告 (China Financial Stability Report). China Financial Publishing House, 2005.
} 
acquiring a relatively independent position in dominating and enjoying a share of the profit from capitalization of local resource around the country, thereby drawing open China's curtain on "financializationdeepening". That of course had a profound impact on China's economy.

On one side, financial capital controlled by the central government became a capital force taking the tide to join in the global competition. That was consistent with the development orientation that the core nation was leading in globalization. The other side was that it had resulted in debilitating local government's ability to acquire funds and worsening the financing environment of small/medium enterprises under diluted profitability.

At the same time, following large scale closing and merging of financial institutions at below county level, state-owned monopoly financial sector also withdrew from peasant agriculture and scattered non-agricultural industries in rural regions, which were plagued by exceptionally high transaction costs and liquidity deficiency.

This institutional transition wherein China's financial capital was alienated from industrial capital had been completed in 2002, coincident with China's accession to the WTO. What followed was the third wave of "land enclosure" campaign since the Reform, initiated by the local governments as a way of acquiring financial capital through cashing in land.

Actually, our understanding of the 'institutional costs transfer' could not possibly have been a priori. It was only after such transaction costs had been increasingly expressed as large scale social confrontations, threatening political stability, that the central government would, as the principal fund provider, request financial institutions to execute a series of interventional relief policies by the will of the state. Among these, the one that had typical significance was State Council's entrustment to the Agricultural Bank the mission of 'serving the sannong'. The Agricultural Bank was listed on the stock market in 2008, the last of the major four state-owned banks to complete commercialization reform. That mission was an important reason why China has the biggest number of agricultural financial institutions and the highest proportions of peasant credit needs to be met among developing countries. 


\section{A Review of the Evolving Relationship Between Financial Capital and Real Industry in China}

Here, we may give a brief review of the changing relationship between financial capital and real industry from the early 1980s till 2002.

\section{The 1980s: Local Financialization Propelled Local Industrialization}

In the name of marketization, there had been several rounds of financial reform in China. However, few have ever conducted comparative research on the contents of "market" referred to in different periods.

According to common discourse, China's "economic and financial market system" emerged in the 1980s. To illuminate the contexts of these changes, we must, however, jump out of the banking sector.

During the state-dominated industrialization before 1980s, investment plans were mainly made by the national planning system. The fiscal budget then allocated funds to these projects. Insufficiently financed sectors were funded by public bonds or increasing money supply. Financing by the private sector was nearly absent. Hence, the financial system by that time was a unified regime in which the People's Bank of China was in charge of all financial business. PBoC managed balancing regulation at macro level and provided commercial service at the same time. In the words of Mao Zedong speaking to Chen Yun, fiscal faculty and the banking sector were no more than two pockets of the man in charge of economic and financial affairs.

The reform of separating finance from fiscal faculty was not motivated by endogenous drive within the financial system itself. In our previous discussion on the 1978-1981 crisis, we have shown that it was the result of attempts to shrug off fiscal budget constraints by the central government facing serious economic crisis. One of the three major reforms in the early 1980s was the shift from fiscal allocation to loans to state-owned enterprises as the state's fiscal revenues were not enough to support the investments. These enterprises had to gain loans from banks instead of getting funds from the fiscal budget. Therefore, the business of loaning, 
along with the risk, had to be separated from $\mathrm{PBoC}$ and managed according to financial logic. A double-decked banking system thereby took shape: the commercial finance and the $\mathrm{PBoC}$ turned into the central bank. In this system, the central bank focuses on macro-regulation, monitoring and providing services to banks, such as inter-bank settlements and clearance while commercial financial institutions provide services to businesses and citizens.

Under the "government corporatism" regime in which the state directly performed the function of capital accumulation, it was impossible for nominally commercial banks established by the government not to carry the policy responsibility commanded by the state. For example, if a state-owned enterprise was short of funds to pay the employees, then the big four banks might have to support it. Each of these big four had its own policy-oriented business. It's worth noting that many of these demands for policy support came from local governments.

Many researchers may selectively forget the fact that what emerged at almost the same time with the reform from fiscal allocation to loaning to enterprises was the influential "Central and Local Stratified Fiscal Responsibility System" in 1984 which resulted in two consequences.

1. Under the previous "central government corporatism" responsible for state industrialization, there was only one centralized ledger. However, there were subsequently nearly 70 thousands fiscal ledgers in the whole country after the reform with 65,000 county and township units. Here came the era of local industrialization dominated by local government corporatism.

2. The fiscal autonomy enjoyed by local governments had promoted local tax revenues. By that time, local authorities could share $70 \%$ of their total revenues. Merely 30\% went to the central government. Under this arrangement, the central government found it very hard to carry its macro-regulation policy. Eventually, under the severe condition of serious fiscal deficits later in early 1990s, all the interested parties were impacted. After negotiation, the Tax Revenues Division Reform in favour of the central government was put forward in 1993 (see previous chapter). 


\section{Box 4: Local Fiscal Budget Soft Constraint and Financial Deepening} Fan Gan points out that under the power division system, local governments and enterprises had the right to approve projects on their own. The fight among these local units to get more resources was expressed as competition for capital fund. Under a "soft budget constraint," the more capital fund one got, the more revenues it would generate and the more advantages it could have. Therefore, in the soft constraint competition among various local governments and enterprises under state-owned economy power division system, the demand for capital fund tended to be unlimited. This competition for capital might be fiercer than market competition in some aspects.

A financial market system built against this context would only serve the characteristics of local government corporatism, providing capital fund to the primitive accumulation for local industrialization. Otherwise, the institutional transition of shrugging off fiscal budget would never be successful.

Understandably, the right to appoint and manage personnel in local state-owned banks was granted to local governments in the 1980s. During this period, the operation of bank branches tended to prioritize local interests. To compete for capital fund, local governments and state-owned enterprises joined hand in hand to force the central government to expand credit scale, thus having de facto power to create money supply. The right of investment planning was decentralized to the local. The local branches of the central bank operated according to local interests. The interests of the central bank, the specialized banks and local branches worked in accordance with local governments, local economy and local enterprises. As a result, a "reverse mechanism" in which local bodies were pushing the expansion of credit loans and money supply took shape. Local governments and enterprises found it easier than before to satisfy their desire to expand investment.

It could be seen in the fact that the actual money supply generally exceeded the planned figure by the central government (see below table).

Table: Actual and Planned Money Supply 1983-1992 


\begin{tabular}{|c|c|c|c|c|c|c|}
\hline & \multicolumn{3}{|c|}{$\begin{array}{l}\text { Loan increment (100 } \\
\text { million) }\end{array}$} & \multicolumn{3}{|c|}{$\begin{array}{l}\text { Cash increment (100 } \\
\text { million) }\end{array}$} \\
\hline & $\begin{array}{l}\text { Planned } \\
\text { (1) }\end{array}$ & $\begin{array}{l}\text { Actual } \\
(2)\end{array}$ & $(2) /(1)$ & $\begin{array}{l}\text { Planned } \\
\text { (3) }\end{array}$ & $\begin{array}{l}\text { Actual } \\
\text { (4) }\end{array}$ & $(4) /(3)$ \\
\hline 1983 & 354 & 378 & 1.07 & 80 & 90.7 & 1.51 \\
\hline 1984 & 423 & 988 & 2.34 & 80 & 262.3 & 3.28 \\
\hline 1985 & 715 & 1486 & 2.08 & 150 & 195.7 & 1.30 \\
\hline 1986 & 950 & 1685 & 1.77 & 200 & 230.5 & 1.15 \\
\hline 1987 & 1225 & 1442 & 1.77 & 230 & 236.1 & 1.03 \\
\hline 1988 & & 1518 & & 200 & 679.5 & 3.40 \\
\hline 1989 & & 1851 & & 400 & 210 & 0.53 \\
\hline 1990 & 1700 & 2757 & 1.60 & 400 & 300 & 0.75 \\
\hline 1991 & 2100 & 2878 & 1.37 & 500 & 533 & 1.07 \\
\hline 1992 & 2800 & 3864 & 1.38 & 600 & 1158 & 1.93 \\
\hline
\end{tabular}

Source: Fan Gan, 'Soft Constraint Competition and Inflation of China in Recent Years,' 金融研究 (Financial Research), 1994(3).

The local soft budget constraint with subsequent reverse forced credit expansion explains high speed local industrialization after the power division reform as the concession by the central government. Compared with the Planned Economy Era 30 years ago, the financial deepening after 1980s moved ahead at extremely high speed. It helped the economic development (the substance of which had been the capitalization of resources) out of the 1978-1981 cyclic crisis. However, it also sowed the seed of deflation in the late 1980s. By estimate, China's financial asset expanded by 12.4 times from 1978 to 1991 while the ratio of total financial asset value to GNP jumped from $95.2 \%$ to $233.8 \%$ (see Table $1)$.

It is commonly agreed that China has achieved high speed economic growth and local government corporatism played an important role. However, few are aware of the function of localized financial tools to the growth. It followed a chain reaction. Local official promotion was determined by local economic growth which was achieved by investment growth. Therefore local governments fought for financial resources, which involved competition among financial institutions. Under this low cost-effective circle, the much admired high speed growth during local 
Table 1 China's financial assets 1978 and 1991 (Unit: RMB 100 millions)

\begin{tabular}{|c|c|c|c|c|c|}
\hline & Items & 1978 & $1978^{*}$ & 1991 & $1991 *$ \\
\hline 1 & Cash & 212 & 5.9 & 3177.8 & 16.2 \\
\hline 2 & Saving Deposits ${ }^{1}$ & 210.6 & 5.9 & 9110.3 & 46.5 \\
\hline 3 & Enterprise Deposits & 902.5 & 25.2 & 7061.7 & 36.1 \\
\hline 4 & Treasury Deposits & 187.4 & 5.2 & 504.3 & 2.6 \\
\hline 5 & Securities & 0 & 0 & 114.2 & 0.6 \\
\hline 6 & $\begin{array}{l}\text { Deposits in Non-banking } \\
\text { Financial Institutions }{ }^{2}\end{array}$ & 0 & 0 & 1421.1 & 7.3 \\
\hline 7 & $\begin{array}{l}\text { Reserve in Insurance } \\
\text { Sector }^{3}\end{array}$ & 15 & 0.4 & 190.8 & $1.0^{* *}$ \\
\hline 8 & $\begin{array}{l}\text { Total Credit's Rights in } \\
\text { Financial Institution (1-7) }\end{array}$ & 1527.5 & 42.6 & $21,580.2$ & 110.2 \\
\hline 9 & Total Bank Loans & 1850 & 51.6 & $18,061.4$ & 92.2 \\
\hline 10 & $\begin{array}{l}\text { Urban and Township Credit } \\
\text { Union Loans }\end{array}$ & 40 & 1.1 & 2124.9 & 10.9 \\
\hline 11 & Trust Institutional Loans & 0 & 0 & 1211 & 6.2 \\
\hline 12 & Government Bonds & 0 & 0 & 1168.2 & 6 \\
\hline 13 & Enterprise Bonds & 0 & 0 & 386.8 & 2.1 \\
\hline 14 & $\begin{array}{l}\text { Total Credit's Rights in } \\
\text { Non-financial Sector } \\
(9-13)\end{array}$ & 1890 & 52.7 & $22,952.3$ & 117.2 \\
\hline 15 & $\begin{array}{l}\text { Bank Loans to } \\
\text { Governments }\end{array}$ & 0 & 0 & $1174.5^{* * *}$ & 6 \\
\hline 16 & Stocks & 0 & 0 & 75.1 & 0.4 \\
\hline 17 & Total Financial Assets & 3417.5 & 95.2 & 45,782 & 233.8 \\
\hline
\end{tabular}

Notes

${ }^{1}$ Included postal savings and savings in Urban and township credit Unions

${ }^{2}$ Included various financial trust investment institutions and urban credit unions. Individual savings in these institutes not included

${ }^{3}$ Sum of responsibility reserve, life insurance reserve and property insurance reserve

* Ration to GNP in 1978 and 1991

** Originally '9.7'. According to other data, it should be 0.97 , approximately 1.0 $* * *$ Originally 1074.5. According to other data, it should be 1174.5

Source Xie Ping (谢平)， '中国金融资产结构分析' (Analysis on China's Financial Asset Structure), 经济研究 (Economic Studies), 1992(11)

industrialization was in fact pushed up by even higher financial growth (see Table 2).

Take rural enterprises as an example. Much research has shown the importance of credit creation in the formation and expansion of rural enterprises. The State Council Rural Development Research Centre and National Bureau of Statistics Rural Sampling Survey Team conducted in 
Table 2 Financial assets/GNP ratio in China, 1978-1991

\begin{tabular}{llcc}
\hline & $\begin{array}{l}\text { Financial assets balance (100 } \\
\text { millions) }\end{array}$ & GNP (100 millions) & Ratio (\%) \\
\hline 1978 & 3417.5 & 3588.1 & 95.2 \\
1979 & 4000 & 3988.1 & 100.3 \\
1980 & 4945.8 & 4470 & 110.6 \\
1981 & 5782.7 & 4773 & 121.1 \\
1982 & 6906.3 & 5193 & 133 \\
1983 & 7759 & 5809 & 133.6 \\
1984 & 10,543 & 6962 & 151.4 \\
1985 & $12,808.7$ & 8557.6 & 149.7 \\
1986 & $16,868.3$ & 9696.3 & 174 \\
1987 & 20,932 & 11,301 & 185.2 \\
1988 & 25,127 & 14,018 & 178.1 \\
1989 & 30,117 & 15,916 & 189.2 \\
1990 & 37,233 & 17,686 & 210.5 \\
1991 & 45,782 & 19,580 & 233.8 \\
\hline
\end{tabular}

Source: Xie Ping (谢平)，“中国金融资产结构分析' (Analysis on China's Financial Asset Structure), 经济研究 (Economic Studies), 1992(11)

1986 a systematic research in 10 provinces. 200 samples were selected from 319 large rural enterprises. The result showed that of the initial capital in the sample enterprises, $4.02 \%$ came from the state's disbursement, 29\% from the Agriculture Bank loans, 5/16\% from credit unions loans, $4 \%$ from the Industrial and Commercial Bank, 5.84\% from low-interest revolving fund by the government, $23.6 \%$ from collective's accumulation, $5.43 \%$ from factory workers fund-raising, $2.9 \%$ from pre-paid sale, $7.89 \%$ by manufacture processing, $0.69 \%$ from jointventure investment, $1.06 \%$ from group or personal sponsorship, other $8.88 \%$. Furthermore, the annual investment of the sample enterprises far exceeded the retained profit and even the total profit that year. In 1984, the average investment amounted to 416.3 thousand yuan, $109 \%$ of total profit and $276.0 \%$ of retained profit; in 1985 , that became $115.6 \%$ and $267.5 \%$. On average, of the newly increased total fixed assets, new bank loans and other debts in that year amounted to $58.6 \%$ in $1984,48 \%$ in $1985,64.7 \%$ in 1986.

According to a study by Lu Yang, during the 1980s, of the total 327.3 billion yuan investment in rural enterprises, $53.65 \%$ came from 
bank loans or inter-companies loans. Self capital investment amounted to merely $33.86 \%$.

Even among South Suzhou rural enterprises during the early rural industrialization where internal community capital accumulation was significant source of investment fund, debts had replaced collective accumulation as the major means of asset formation. In 1984, the growth of loan was up to $83.52 \%$ among Suzhou rural enterprises, nearly 60 percentage points higher than the $24.64 \%$ growth rate of self capital. Instantly in that year, the total debt to asset ratio of rural enterprises in Suzhou rose to $51 \%$. Total debts for the first time surpassed owners' equity.

There are two more noteworthy points. First, some researchers suggested that even though credit was essential in the rapid economic development of outside-state-apparatus rural enterprises, its weight in the total financial provision was less than $10 \%$ (see Table 3), which indicated the scale of loans by financial institutions to the state-owned sector.

Second, the large-scale financial expansion in the 1980s was different from the times of newly born Renminbi when money supply increase was the only means to deal with fiscal deficits. Now financial expansion took place at local level. It had little effect on relieving fiscal deficits.

\section{4-2002: The Re-Centralization of Finance and Its Alienation from Local Industries}

The cost of financial localization as an institutional change was emphasized by researchers in later financial reform. Bad loans were mounting in the financial system as local governments sought rapid development. Confronted with economic overheating, the government started in 1993 to take regulative measures in different sectors: fiscal budget, finance, trade and balance of payments etc. Then in 1997, just after the government announced economic 'soft-landing,' the Asian Financial Crisis raised the alarm of systemic risk to the Chinese economy. Financial reform was necessary to face the challenge of globalization. The cancers of bad loans were cut off from banking sector as described earlier. 
Table 3 Loans to non state-owned sector from financial institution 1985-1996 (Unit: \%)

\begin{tabular}{|c|c|c|c|c|c|c|}
\hline Year & $\begin{array}{l}\text { Urban } \\
\text { collective }\end{array}$ & $\begin{array}{l}\text { Urban } \\
\text { individual }\end{array}$ & $\begin{array}{l}\text { Rural } \\
\text { enterprises }\end{array}$ & $\begin{array}{l}\text { Three types } \\
\text { of foreign- } \\
\text { funded } \\
\text { enterprises }\end{array}$ & Agriculture & $\begin{array}{l}\text { All } \\
\text { non-state } \\
\text { sector }\end{array}$ \\
\hline 1985 & 4.95 & 0.17 & 5.63 & - & 6.85 & 17.60 \\
\hline 1986 & 5.11 & 0.13 & 6.82 & - & 6.68 & 18.94 \\
\hline 1987 & 5.47 & 0.16 & 7.25 & - & 7.28 & 20.16 \\
\hline 1988 & 5.58 & 0.17 & 7.59 & - & 7.19 & 20.53 \\
\hline 1989 & 5.15 & 0.11 & 7.39 & - & 7.12 & 19.97 \\
\hline 1990 & 4.93 & 0.09 & 7.42 & - & 7.17 & 19.61 \\
\hline 1991 & 4.74 & 0.08 & 7.63 & - & 7.39 & 19.84 \\
\hline 1992 & 5.77 & 0.26 & 7.16 & - & 7.54 & 20.73 \\
\hline 1993 & 5.96 & 0.33 & 8.22 & - & 6.47 & 20.98 \\
\hline 1994 & 5.08 & 0.38 & - & 1.94 & 11.38 & 18.78 \\
\hline 1995 & 4.26 & 0.39 & - & 1.98 & 5.99 & 12.62 \\
\hline 1996 & 4.31 & 0.46 & - & 2.20 & 11.65 & 18.62 \\
\hline
\end{tabular}

Sources: Tao Shigui (陶士贵), “地方政府控股下的地方银行制度变迁逻辑与风险防范' (Institutional Change of Local Banking System with Local Governments as Stock-Holders: Logic and Risk Prevention), Nanjing Normal University Journal (Social Sciences), 2013(5). 1985-1991 data from Mai Jingnong (麦金农), 经济 市场化的次序一向市场经济过渡中的金融控制 (Order of Economic Marketization: financial control during transition to market economy), Table 13. Shanghai Joint Publishing House and Shanghai People Press, 1997; 1992-1996 data calculated according to 中国金融展望 (China Finance Outlook 1994-1997)

\section{3-1996: Background of Contractionary Financial Policy}

After the fiscal division in 1984, factional local governments competed out of their own interests. Local authorities at various levels used their power to intervene in bank investment decision-making. However, since many of these investment projects were based on irrational exuberance and trend-following, they ended up as bad loans in banks. However, the financial risks encountered during this period would be dwarfed in comparison with the situation after 1992.

After Deng Xiaoping's inspection trip to South China in 1992, the three speculative markets (stocks, futures and real estate) were liberated. The autonomy of local governments in economic development was further expanded, especially in terms of their financing and financial power. 
Fan Gang pointed out that the following two were of utmost importance.

First, local governments had total power in decision-making related to investment projects. At the municipal level, the limit of autonomous investment project was raised to 30 million yuan, and at provincial level, 50 million. As a result, fixed asset investments rocketed. During January to May 1993, fixed asset investments in state-owned sector increased by $70.7 \%$ compared with the same period in previous year.

Second, autonomy in financing was the most important right granted to local governments and state-owned enterprises. It was used to evade central government's credit control and monetary policy. Direct financing allowed them to get the funds required at interest rates much higher than the general saving interest rate. In 1992, the total marketable securities in China amounted to 128 billion yuan, including 41 billion of public bonds, 12.7 billion of investment bonds by the National Investment Company, enterprises bonds 37.9 billion, financial debts 25.5 billion, stocks 10.9 billion, which were formal securities shown in statistics. According to the estimate by the People's Bank of China, the total value of "informal securities" such as enterprises internal stocks, planned financing, etc., might be up to 220 billion yuan, of which, besides 25.5 billion of financial bonds, 194.5 billion was direct financing, amounting to $54.6 \%$ of new bank loans in that year and $46 \%$ of total new debts in financial institution (including state-run banks, trust investment and urban-township credit unions).

The combination of these two autonomies led to expansion of money supply and investment. In 1992, currency in circulation increased annually by $36.4 \%$ and in $1993,35.3 \%$. In 1985, the total fixed asset investment amounted to 254.3 billion. In 1990, it had raised to 445.1 billion. It rocketed to 1182.9 billion in 1993 and 1600 billion in 1994!

Just a step out of contraction, the economy bumped into high inflation. It was estimated that the real inflation rate was rising from 1993 to 1995 . The official statistical number peaked at $24.1 \%$ in 1994 . Take two indexed bonds with 3 and 5 years maturity (000093 and 000193) as example. They were valued at 100 yuan when issued in 1993 and redeemed at 171.99 yuan three years later in 1996. That implied an annual inflation rate of up to $24 \%$. 
Each occasion of high inflation would impact the real economy. In 1993, the entire society had to bear the institutional cost of increased money supply.

There was remarkable change in enterprise cost structure. Enterprise capital deepening and industry upgrade were thereby inhibited. It facilitated rent-seeking by interest blocs while non-state-owned sectors had to bear greater institutional costs. For example, because of interest blocs in state-run sectors, loan interest was suppressed at a very low level. Loan interest was actually negative, lower than the inflation rate and became the most serious distortion in the Chinese economy. By that time, the non-state-run economy had accounted for over $60 \%$ of GDP and $30 \%$ of investment. However, $80 \%$ of bank loans went into the state-owned sector. At the same time, the state was developing the speculative capital market. Financial capital, by essence, seeks liquidity for profit-making, which could not be suppressed by administrative means. Unauthorized lending or speculation was unstoppable in the financial sector. Capital gray markets were pervasive. A large amount of low-interest rate loans became the source of rent-seeking by banks, government officials or state-owned enterprises. Domestic capital market interest rate constantly stayed at about $20 \%$ per month. Loan-sharks were rampant in the whole country. Small and medium enterprises were being squeezed out from normal lending.

The local sector fought for financial resources in order to internalize the gain of resource capitalization while striving to externalize the cost of financial risk, which expressed itself in a banking crisis and in inflation. To deal with economic overheating, the central government released signals of tough regulative measures. However, the signal of imminent regulation in turn increased the urgency of local about-to-belaunched projects. Overheating was intensified during 1993-1994. The central government was then forced to take stringent instead of mild measures. The game of interest and power between the central and local governments had once again led to economic fluctuation in China. 


\section{The Impact of Financial Austerity Policy During 1993-1996}

Central regulative measures were put forth amid the tide of enterprises expansion and capital deepening through loans. Even though the target was speculative overheating, the real economy at county level, especially township enterprises were hit hard, as the central government, out of information asymmetry, cut all loan scale by rigid uniformity and tightened the right to approve lending. Banks then suppressed lending scale at and below county level. The intimate relationship between local financial localization and local industrialization started to change.

After 1994, state-run banks strengthened vertical leadership system and internal control. Financial institutions, especially banks would contract credit as systematic risks increased. Regarding the recipients of credit, the governments however did not relinquish policy favouritism towards state-owned large and medium enterprises and continued to subsidize unprofitable state-owned enterprises. Under credit rationing management, the opportunity cost of non state-run economy to get financial support became higher. Furthermore, the assets structure of many small and medium enterprises was not recognized by banks. They found it hard to get financing from formal financial market.

From the perspective of a complete economic cycle, whether during the credit expansion period of 1992-1993 or the contraction of 19941996, the financing condition of the real economy was structurally unfavourable. In the previous period, enterprises in the real economy were being squeezed out because financial capital was seeking after highrisk, high-return speculative realms. In the later period, they had to bear un-proportionally the institutional cost of economic regulation.

Regarding credit loans to rural enterprises from formal finance, the values amounted to 151.79 and 196.28 billion yuen in 1992 and 1993 , a growth of 36 and 44.5 billion compared with previous year while the total national credit volume increased by 498.51 and 662.02 billion respectively. After austerity policies were implemented in 1994, total credit loans to rural enterprises were cut substantially, from 7 to $8 \%$ of total national credit volume to $3-4 \%$. In 1994, credit loans to rural enterprises valued at 200.24 billion, with an increase of merely 4 billion 
compared with previous year while the total new credit loans in the whole nation amounted to 703.29 billion.

In 1996, the ratio of credit loans from financial institutes to rural enterprises fixed assets investment declined to $24.56 \%$, a drop of 3.66 percentage points. Moreover, the credit structure in that period also had significant change. Short-term loans in financial institutes grew by $17.2 \%$ while long-term merely $6.66 \%$. It was remarkable compared with the figure of $87.9 \%$ and $24.2 \%$ in 1994 as well as $35.25 \%$ and $20.71 \%$ in 1995.

During 1986-1991, bank loans to rural enterprises grew annually on average $31.85 \%, 1992-1995,30.88 \%$. And during 1996-1997, the average annual growth rate was merely $9.35 \%$.

In retrospect, the macro-regulation during 1993-1996 was instrumental in stabilizing the national economy and its finances. China successfully took precautions before the Asian Financial Crisis in 1997. However, the institutional cost, the price of soft-landing, was unevenly shared between different types of enterprises, between urban and rural sectors as it was in previous reforms, the remarkable asymmetry of costs and benefits.

\section{7-2002: Banking Commercialization Reform and Its Aftermath}

After the 1993-1996 regulation, we witnessed the banking reforms during 1998-2002 in which local financial resources were further constrained. This was also conventionally dubbed as marketization since the 1980s. A slight difference is the clarification of the commercial goal of banking reform. From then on, the banks have become independent entities of interest and profit seeking for even higher profitability.

After the 1997 crisis, the central leadership was resolved to push banking reform (see above column: State-owned Banks Commercialization Reform).

As the central government took over the historical bad debts in the local financial sector and, hence, regained its control on banking, state-run commercial banks replaced the 'administrative logic' with 
'market logic'. The allocation of financial resources was strictly conducted according to market principle. The age of 'Three Eyes of Local Branches' (being inspected by the headquarter, local government and regulation authority) had gone.

As stated above, the bad debts in banking system accumulated along with speeding local industrialization. They may be regarded as the side products of financial localization in support of local industrial expansion. Furthermore, rural enterprises that thrived under a particular institutional arrangement of peasant community may not be well served by Anglo-Saxon banking model (generally seeking after profit through liquidity) as the former's assets (such as land and natural as well as cultural resources) are not as explicit as in their urban counterparts. Therefore, they usually record higher debt asset ratios. Whether AngloSaxon risk rating system suits the particular situation of China deserves further exploration. No matter what, the institutional transition set in motion by the central government to reduce systematic financial risk did take the responsibility to deal with the risk generated in previous round of local industrialization. However, it did not provide an alternative institutional solution to local financial provision. The formal channel of local access to financial resources was blocked. As a result, the benign symbiosis between financial capital and real industry was debilitated.

In the twenty-first century, Chinese financial capital turned to the speculative sector such as real estate and derivatives market to seek monopolistic returns. Industries with lesser liquidity or profitability were increasingly being alienated by capital. It did improve the risk of investment loss because of the alliance between local governments and finance. However the policy jumped from one extreme to the other. Under deficiency of new financial tools to support local industry, the institution transition to promote profitability and reduce risk in financial system would necessarily pass the institutional cost to real industry, especially numerous small enterprises failing to get credit guarantees from the state or local governments. Consequently, we have on the one side the local deindustrialization all over the nation, and on the other, the 'embarrassingly fat profitability' (as uttered by a state-owned bank CEO) in the state-owned banking sector. 
From 1984 to 2003, Chinese finance took 20 years to complete the circle from a 'centralized system' to 'localization' and to 'recentralization'. Under the free market doctrine, speculation-rush is regarded as normal market behaviour. Macro regulation for the sake of constraining speculative bubble at the end threw the baby out with the bathwater. The real economy suffered a three-fold hard blow: the squeeze-out effect of speculative capital, the austerity of economic regulation and financial alienation after banking reform.

It is noteworthy that what is described above is more than a phenomenon with Chinese characteristics. Instead, it is a syndrome pervasive in the Anglo-Saxon-American model of finance. Before the 2008 Financial Tsunami swept the world, China had suffered from the structural imbalance between financial capital and real economy. If we jump ahead a bit here, we may see that the seeds of the 'new normal' of economic deceleration after 2013 were actually sowed twenty years ago in 1993.

\section{Proactive Fiscal Policies-Infrastructure Construction Investments Mainly by the Central Government}

In response to the change in domestic supply and demand relationship as well as the impact of Southeast Asian financial crisis on exports, the Central government promulgated in 1998 Document No. 3 and No. 12, proposing domestic demand expansion and adopting a series of relevant measures. That in fact marked a change in keynote policy orientation, from moderate suppression of domestic demand since 1993 to active expansion.

In early March of 1998 when the new administration took office, the proposal for "proactive financial policies" to relax bank investments was put forward. However, the marketization reform to insulate the banking sector from local government intervention had already been on track. Bank branches at county level had handed over most of their financial power to higher provincial counterparts. They could now only approve loan no more than 200,000 yuan. Therefore, it was not possibly for local 
administrations to expand bank investments on a large scale to comply with the new instruction from the central government.

Therefore, starting from the summer of 1998, the central government went on to implement an expansionary fiscal policy. That policy adjustment which began in early 1998 had originated with a report from Li Nanqing, Vice Premier in charge of foreign trade, to the Chief Party Secretary, Jiang Zemin on January 6, about the proportion of GDP growth attributable to export would likely decline from around 4 percentage points in 1997 to less than 1 due to the impact of the Southeast Asian financial crisis. On that basis he requested the central government to make policy adjustment in time to expand domestic demand and reduce over-reliance on exports. Jiang approved the report and the Premier Zhu Rongji, who just announced in 1997 the 'soft landing' of the previous crisis with completion of macro-regulation, was put in charge of the proactive fiscal policy of issuing large scale national bonds to expand investments. ${ }^{10}$ These public debts were mainly invested towards infrastructure constructions.

From the aspect of economic operation, the effect of driving demand growth by government-led investments in 1998 was very obvious. Investments in state-owned sector recorded a growth of $19.5 \%$ as compared to $6.1 \%$ in urban/rural individuals and a decline of $3.5 \%$ in urban/rural collectives. Among the investments in state-run sector, the largest proportion was infrastructure, accounting for 56\%, a growth as high as $20 \%$. Renovation and reconstruction had accounted for $21 \%$, with a growth of $13.9 \%$; and real estate development $17 \%, 12.6 \%$. It can be seen that the economic growth in 1998 was mostly driven by state investments. In conjunction with other analyses it can be concluded that the economic growth rate in 1998 was prevented from further falling because of state investments to expand domestic demands. ${ }^{11}$

\footnotetext{
${ }^{10}$ From 1998 to 2000, 360 billion yuan of long-term national building bond was issued. Xu Hongyuan (徐宏源), 2000年中国宏观经济形式分析与2001年展望 (Analysis of China's Macro Economic Form in 2000 and 2001 Outlook), Economic Forecast Department, National Information Center. http://www.cei.gov.cn/template/economist/yth_source/zgjj20010 10203.htm.

${ }^{11} \mathrm{Ma}$ Hong and Lu Baifu (马洪,陆百甫), 中国宏观经济政策报告 (Report on China’s Macro Economic Policy), China Financial and Economic Publishing House, January 1999.
} 
It was not only in the year of implementation of proactive fiscal policy that the Chinese economy was able to counter much of the harmful impact on growth due to substantial export contraction. In the following 1998-2000, 3 years of relative depression, the national economy had been able to sustain a growth rate "below 8 and above 7 ". In addition, the constraint of inadequate infrastructure investments in the past had to a large extent been improved. For example, the construction of the first highway in China-Hu-Jia Expressway from Shanghai to Jiading-had ushered in a wave of expressway construction. By 2003 when the next administration took office, the mileage of China's expressway was second in the world, after the United States.

\section{"Government's Entrance" as the Fundamental Experience for China in Response to Imported Crises}

There is a saying "great luck amidst misfortune". It was an apt description for China in its first encounter with the imported crisis in 1997-1998 pursuant to the East Asian financial crisis. In fact, 1998 should be a year worth noting in history because the government has since then adopted the approach of directly using public debts to expand investments on a large scale to "turn crisis into opportunities". After that, China had enlarged government bond issuance for twelve consecutive years, initiating investments of around 10 trillion yuan. During this period, a whole series of major national strategies to adjust regional and urban-rural disparities were successively put forward.

Urban-rural, regional and rich-poor disparities subsisted in China due to factors such as geographic vastness and three-tier terrace topographic structure as well as market selection. These gaps had been widening continuously and become a subject of criticism. And under the pressure of crisis with export contraction and over-production, the under-developed regions and rural areas in China became the state's principal targets to expand investments!

For example, the Western Region Development strategy was put forward in 1999. It included large scale ecological improvement projects such as natural forests protection, forestation and grass-planting to revert 
ecological destruction in dry grassland and mountainous forestry regions due to funding deficiency in the past. In 2001 the strategy to revive the old industrial regions in northeast was proposed. President Jiang Zemin stressed in particular "supporting Northeastern region to accelerate rebuilding as well as adjustments of old industrial cities, and resource-extraction cities to develop sustainable industries". It effectively alleviated social disorder and the emergence of slums and shacks in old industrial cities in those areas. And in 2003 when the new administration took office, the strategy of central region development was proposed. In 2005 another major strategy in the name of "building socialist new countryside" was put forward to continuously increase rural infrastructure investments.

This direct government intervention into the economy, propelling the real economy through public debt expansion and increasing money supply to stimulate economic growth, could be regarded as the "reentrance" of government (after the state had retreated from social provisions in different realms since the 1980s). Having effectively dealt with the imported crisis of 1997, "government entrance" became the fundamental experience for countering economic crisis caused mainly by external factors.

A particularly noteworthy point was that this region-balancing development strategy through direct investments by the government to alleviate the "market malfunctioning" had not stopped with the change to the new administration. On the contrary it continued for more than twelve years starting from 1998. The total investment supported by public bonds was valued at more than 10 trillion yuan. There were also regional financing platforms below provincial level. The total investment from various levels of governments amounted to around 20 trillion yuan. The large scale increase of investments not only improved the situation of deficiency in infrastructure investments in the past, it became the principal measure that China used unwaveringly to sustain high growth in the first decade of this century.

Nevertheless, any proactive measures would have passive impact as well as criticisms from different vested interest groups. At the same time when public bond-sponsored projects had stimulated the economy and reduced regional disparity, the situation of "state advances and private 
sector retreats" arose, given that the mega projects were mostly executed by state-owned enterprises. That ignited heated public criticisms both domestically and externally that the government had intervened too much and caused a regression of privatization reforms. On another front, it also gave rise to a 'rough growth' inertia, simply using more investments to attain growth but also creating more over-production, which amounted to "making use of greater over-capacity in the future to cover today's over-capacity", leading to greater potential risks over time. In case an unexpected factor blocked this economic process of 'high investment + high consumption + high dependency', the entire national economy would be thrown into chaos.

Regarding the situation of "state advances, private sector retreats" that has emerged objectively, given that Western countries had adopted similar tactics of nationalization in dealing with the 2008-2011 financial crisis, the domestic pro-Western public opinions became somewhat mute. As for the over-reliance on foreign energy sources and raw materials, while it was regrettable it was nevertheless inevitable, since the domestic facilities developed over the past few decades were indeed insufficient to alleviate the difficulty. The Chinese, on the one-way road of investment-driven growth, could only rely on the international order maintained by the U.S. with its allies. In order to acquire the right to development in a global regime under effective US control of the global resource markets and logistic channels, China had to pay tribute of 'dual export' to the U.S. (exporting goods at low price and channeling the hard-earned dollar back to the US to support the US treasury bond market).

Admittedly, certain measures taken by Chinese government to strengthen strategic security have been relatively effective. For example, since 2003 subsidies have been granted to staple crops production and in 2004 agricultural tax was abolished. A whole series of proactive measures have given rise to grain production increases for nine consecutive years, reaching more than 550 trillion kilogram in 2011. During this period, although China was listed in 2008 by international organizations among the 37 "hungry countries" vulnerable to high food price caused by the financial crisis, China was the only one among these countries that did not actually have hunger. In other aspects, however, the measures were 
not so effective. For example, China began in 2005 to increase strategic oil reserves to strengthen energy security, yet it was no more than a drop in the bucket. China's predicament of over-reliance on imported energy and raw material has become increasingly severe.

\section{Impact of Crisis on the Sannong and Rural Governance}

\section{The Sannong Became the Vehicle to Achieve "Crisis Soft-Landing"}

First, the rural sector under the urban-rural dual system once again played a regulative role as a "labor force reservoir", so that urban unemployment would not flare up to a social crisis. After the 1997 crisis, agricultural employment began to increase year after year, from 348.8 million in 1997 to 368.7 million in 2002, a rise of $5.83 \%$. This portion of "new" agricultural employment might be regarded as the unemployed urban laborers pursuant to onslaught on urban economy, given the urban-rural dichotomy.

Besides, given that the expansionary fiscal policy mainly aimed at urban infrastructure constructions, there was a need for large scale utilization of scarce land resource. Unlike in the past wherein the peak of the economy would coincide with the peak of land enclosure effort, the situation in 1998 was that substantial increase in appropriation of arable land took place during relatively serious economic decline. Overall, while large scale infrastructure construction did indeed build up asset pools in cities, it nevertheless could not avoid the pitfall of the cost of appropriating large areas of arable land. And every time resources were being re-allocated under the condition of worsening governance, there would be possibility of confrontation. From a long term perspective, the compensation policy on land appropriation had not been comprehensive regarding the functions of arable land, and it was not fair either. During 2008-2013, arable land in China shrank by 110.37 million hectare annually. Another problem was that rapid low-cost enclosure of land in the countryside led to serious wastage. Between 1998 and 2002 
the total urban built-up area in 660 cities across the country had annual growth of $5 \%$, yet population growth in the same period was only $1.3 \%$. By 2005, average urban land use per capita was 133 sq. meters, 33 sq. $\mathrm{m}$. higher than that stipulated by state urban planning regulations, and far higher than the level of 82.4 sq. meters in some developed countries. The urban floor area ratio in China was only 0.33 , while it was up to 2.0 in some foreign countries (Jiang Shengsan \& Liu Shouying et el, 2007).

It intensified the scarcity of land resource in a populous country like China. Moreover, the capitalization of land resource also gave rise to large number of confrontations and even mass incidents in rural society due to conflicts in profit allocation.

\section{Impact on Rural Economy and Peasant Income}

This round of depression in the macro-economic cycle was contextualized against a time when China was increasingly integrated into economic globalization dominated by international capital, while domestic over-capacity was emerging on all fronts. It was also a time when the dominant political orientation tended to "ideologize market measures" ${ }^{12}$ All of these had multi-facet impact on the rural economy, peasant income and rural governance.

During the 1994-1996 economic overheating the state had raised the official purchase prices of staple grain, effectively stimulating essential produce production. Then the downward economic cycle in 1997 took effect and urban demand declined. As the economy sank into depression, the problem of over-supply surfaced, with grain price and agricultural effectiveness both falling. The Chinese rural economy became increasingly debilitated since mid —and late 1990s.

Under the combined impact of over-capacity in manufacturing as well as austerity policies, the business environment of rural small-medium enterprises once again deteriorated. Yet rural government's expenditures were mostly inelastic as community welfare, rural authority and

\footnotetext{
${ }^{12}$ The intellectuals and dominant sectors in China all have a tendency to ideologize economic system in order to safe-guard "discourse correctness", whether emphasis on planned economy in the past or on market economy nowadays.
} 
enterprises were interwoven. Hence the loans that rural enterprises had borrowed to finance production were largely diverted to cover local government expenses. Rural enterprises indebtedness went even higher. Local authorities, in attempt to shrug off the debt burden just as their superiors were doing, adopted the policy of privatization with the transfer of indebtedness as a condition. After such reforms rural enterprises no longer had affinity with the local community and the mission to optimize community employment or to take responsibility over community welfare. Given the capitalist mechanism of 'capital intensification excludes labor', rural employment started to decline. ${ }^{13}$

Empirical research showed that in the fifteen years between 1991 and 2006, the growth rate of China's economy had strong correlation with the growth in rural enterprise employment, with Pearson Correlation Coefficient of 0.642 . Considering the problem of statistic scale inconsistency since 2003, we conducted correlation analysis between GDP growth rate and rural enterprise employment growth rate using 19902002 data. The Pearson Correlation Coefficient was 0.648, supporting the conclusion (Fig. 7).

In response to crises in urban sector, a series of reforms were conducted since 1990, including rural financial reform launched in 1998, the main objective of which was to lower the risk in banking sector, and commercialization in education and health care that had the purpose of driving domestic demands, and so on. They had all become financial pumps drawing out scarce funds and resources from rural regions to cities.

Take rural financial reform as an example. Following the progress of the banking commercialization reform, the out flow of funds from the illiquid agricultural realm to non-agricultural and urban sectors had accelerated. The quota of financing that agriculture and rural regions were given by the state banking system had dwindled. By 2002 when the banking commercialization reform was completed, the loans utilized by

\footnotetext{
${ }^{13}$ As early as in 1986, a reputed young scholar Du Ying (later the Deputy Director of National Development and Reform Committee) and Zhou Qiren et el had published a survey report on 200 large rural enterprises, pointing out that the latter's mission of establishment was not the optimization of profit but optimization of community employment. The mechanism of capital excluding labor was put forward by Chen Xiwen (later the Director of Central Rural Affairs Leading Team).
} 


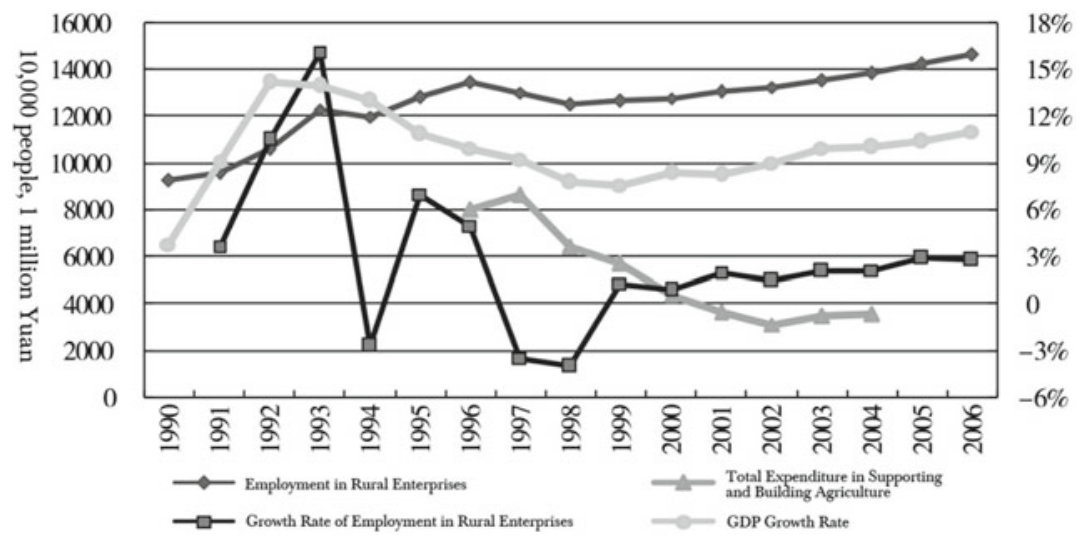

Fig. 7 Rural enterprises employment and contribution to rural community 1990-2006; statistics after 1997 were rural collective enterprises; 2003 and 2004 were large rural enterprises (Source of data: China Statistical Yearbooks and China Rural Enterprise Statistical Yearbooks)

rural regions accounted for only $10.4 \%$ of total loans in the whole society (Chen Xiwen, 2004). The gap between supply and demand of funds in rural sector continued to increase, from 462.3 billion yuan in 1991 to 10.332 trillion in 2004 (Wu Cuifang 2007). Consequentially, rural development was faced with the predicament of fund shortage, thereby spurring the emergence of wide-spread rural usury since late 1990s. In addition, from our field studies performed in Northern Anwei and Northern China, we time and again heard that even grass-root officers would sometimes seek recourse to usury in order to fulfill the taxation requirements. As peasants were generally plagued by heavy levy, there was difficulty in tax collection. The grass-root taxation departments often had to borrow from usury to fill the gap. The heavy interest obligation was then passed onto peasants, resulting in a vicious cycle.

\section{Impact on Rural Governance: The Model of "Self-Financing" for Rural Governance was Again at Danger}

During this period the inelastic government expenditure relating to rural super-structure did not decrease alongside the downward economic cycle 
but on the contrary continued to expand. On one hand it was due to the closing down and bankruptcy of rural enterprises which reduced nonagricultural employment opportunities, thereby increasing the number of people that the grass root fiscal budgets had to provide for. On the other hand, ever since the tax-division system reform in 1994 various upper level governments essentially adopted the approach of "taking up fiscal power but pushing down responsibilities". The provision responsibilities of basic public goods that could not be readily "shrugged off" through simple marketization, such as obligatory education, medical and health care and so on were being pushed down level by level. The peasants, as China's biggest under-privileged group, eventually became the principal agent supplying fiscal funds needed for rural public goods during the 1990s reform (for example, education funding accounted for a large portion of peasant levy). Therefore, from late 1990s till 2004 when the central government announced the abolishment of agricultural tax, the frequent official documents directing that "peasants' burden should not be increased" were a reflection of the fact the load on peasants had continued to increase.

\section{Box 5: Central Government Documents regarding Peasants' Burden in the 1990s}

Sociological studies have indicated that during a particular period of time, the frequency of policies propagation on a certain subject would to some extent be proportional to the severity of that subject in society. After analyzing the material on policy regulations published in the People's Daily since its inauguration in 1946, we found that the issue of peasants being overburdened was first mentioned in the 1990 'Report on the Work of the Government' and since then it had been referred to every year with varying emphasis and frequency. In the 1993 report it was pointed out very clearly that "peasants in many regions had higher production but not higher income; the situation of haphazard fundraising and apportioning to peasants, adding to their burden, was quite glaring."

In the document 'Report regarding the Situation of Increasing Peasants' income and Reducing Peasants' Burden' presented on 30 October 
1999 by the then Agricultural Minister Chen Yaobang, the content quoted below reflects the seriousness of peasants' increasing affliction in late 1990s:

Following the document 'Decisions of CPC Central and State Council regarding Faithful Execution of the Work on Reducing Peasants' Load' in 1996, further policy regulations were launched since last year. Last July, the CPC Central Office and State Council Office sent out the document 'Notice Regarding Faithful Execution of the Work on Reducing Peasants' Load,' clearly indicating that the total absolute amounts to be imposed on peasants in 1998 should not exceed the amount in 1997. The third plenary of the 15th CPC Central Committee affirmed the reduction of peasants' load as one of the fundamental goals in rural work, clearly stipulating that the reasonable amount to be borne by peasants should remain unchanged for three years. This year, the State Council Office forwarded various documents from the Agriculture Ministry, 'Report on Enforcement Inspections Regarding Peasants' Load for 1998' in March, then the document 'Opinions on Executing Well the Work of Reducing Peasants' Burden" in July. In mid-October, State Council convened the national phone and video conference on reducing peasants' load in which vice-Premier Wen Jiabao put forward the clear requirement to further reduce peasants' burden.

In fact, the tension in economy from macro to micro levels at that time led to tension in rural social relationship that was more serious than ever before. A series of reforms since the 1990s had resulted in extreme scarcity of funds at the grass root. The subsequent burden on peasants' shoulders led to wide spread confrontations between peasants and local officers at the turn of the century. ${ }^{14}$

When normal means of levying could not fulfill the target, grass root authorities would generally adopt unusual tactics such as mobilizing the mass to help collect, making loans, collective financing, even employing gangsters to coerce the peasants. Other levying means in disguise-e.g. appropriating land for contracting, levying compensation, fraudulently diverting compensations for relocations or for repatriation of forest and farm land-had also happened in large numbers.

Furthermore, in the Grain Circulation System Reform launched in 1999 for the purpose of facilitating rural financial reform and 'digesting' the funds of Agricultural Bank held up by grain system, various policies

${ }^{14}$ Dong Xiaodan \& Wen Tiejun, 'Macro Economic Volatility and Rural Governance Crisis,' Management World, 2008 (9). 
in favoritism of state sector's monopolization of grain supply included one that required 'collection of peasants' surplus household by household in cash', a change from the past approach of having the grain station handle it collectively. The approach originally had the good intention of protecting the interest of peasants. Yet during execution it became a mechanism causing incidents of mass confrontation. Rural society had become de-organized politically after the reform in 1980s. The marketization of grain system since 1998 further modified the relationship between local authorities and peasants. Peasant households were geographically, socially and politically scattered. It was difficult for village cadres to collect levy without using coercive means. The administrational, political and social costs of village cadres having to collect levy household by household were obviously very high. This high transaction costs between grass root authorities and scattered peasant households intensified the confrontation sharply. Looking from this perspective, the contradiction was the outcome of government's over-mobilization of peasant households for resources in the peasant economy, without being able to resolve the problem of high transaction costs with scattered peasant households (Wen Tiejun 2003).

Because of state involution (Duara 1995), some of its rural grass root personnel reverted to villainous gentry that had existed repeatedly over history in the past. Alliances of 'villainous gentry + elite' were formed with local governing authorities. For example, the Organization Department of the CPC Central Committee promulgated on March 22, 1999 the document 'Opinions Regarding the Strengthening of Building the Rank of Rural Grass Root Cadres' and the People's Daily published on February 9th, 2000 an article about certain typical cases of rural grass root cadres violently handling the mass in Fujian, Hunan, Shandong, Jiangsu and Hainan, which were respectively obverse and reverse reflections of the trend of grass root cadres degenerating into villainous gentry. It then developed further into situation of 'elite capture' and 'clientelism' in rural governance. ${ }^{15}$

${ }^{15}$ The World Bank's World Development Report 2005, regarding government's rent-seeking behaviors, used the terms 'capture' and 'patron-clientelism' to refer to 'the skewing of policies towards certain groups while damaging the interest of other groups due to uneven access to information and their impact on policy-making'. Xie Yue (2005), refers clientelism to 'protector politics' in 
Large number of peasant petition as well as mass incidents happened at that time. Certain local governments, in some circumstances, made use of state apparatus or even gangsters to suppress mass incidents, thereby causing escalation of confrontation and even injuries and fatalities, which then further worsened the rural governance crisis. Kan Xiaoguang et el (2002) believed that Chinese society had since 1990s seen the formation of an elite alliance including political, economic and intellectual elites. They would skew the allocation of interests in the society towards elite groups while forming a stable base for the governing power of the state as a whole. The conflicts in rural regions were 'partial' opposition by the mass under exploitation. Elite alliance was endogenous and highly stable, and once formed were very difficult to break down. Yang Pan (2005) further believed that it was the era of double conflict, the conflict among elites and the conflict between elites and the mass. Although they had different assessments on the situation of competition among elites, yet regarding mass incidents both concluded that they were conflicts between elites (or elite alliance) and the exploited mass.

The direct manifestation of confrontation was mass incidents begun to rise sharply since 1997 (totally over 15,000 in that year) and then more than doubled in two years to 32,000 in 1999. Based on statistics from the police department, the number of incidents was 60,000 in 2003, 74,000 in 2004 and 86,000 in 2005. Although there were no further publicly available statistics after that, from on-line information search the number was more than 200,000 in 2009. About one third of those cases were related to peasants defending their rights. As for petitions, the frequency and causes were basically consistent with the changes in mass incidents, also escalating after 1997. For example, surveys conducted by a joint team of the Henan Academy of Social Science and Henan Provincial Petition Bureau found that people's sentiment was unstable in some rural

China rural society. During the transition under the authoritarian system, the use of public power for self-interest emerged within the interest-exchange network of 'protector-the protected' relationship. The expansion of this kind of network of self-interest had to a certain extent obstructed the normal operation of peasants' self-governance and the development of community self-administration, resulting in the marginalization of legitimate authority. 'Protectors' in the name of executing state authority provided the 'protected' with exclusive services, acquiring economic and political rewards in doing so. In many cases, public resources were appropriated to serve the interests of a handful of persons. 
regions in Henan. Many had mounting distrust towards the county and village authorities. Large scale group petition cases increased year over year, with 187 groups, a total of 24,203 people in first half of 1998, an increases of $33.6 \%$ and $449.7 \%$ respectively over the same period in 1997. ${ }^{16}$

In summary, this imported crisis did not directly transform into depression due to a series of strong intervention initiated by the government in 1998. GDP growth was sustained at 7.8\% in 1997 and $7.6 \%$ in 1998, thus maintaining economic growth and relative social stability. However it gave rise to an unprecedented situation of peasant incomes declining for four consecutive years, which led to insufficient domestic demand and 'deflation'. Furthermore, as the stimulating measures were oriented towards urban sector, the negative impact on the sannong and rural governance was quite severe.

\section{Contextualizing the Fourth Round of Foreign Investments and Foreign Debts in 1997-2008: Collision of External and Domestic Over-Capacities}

At the time before the 1997 crisis, export sector annually contributed over 3 percentage points to GDP growth. A noteworthy factor was the issue of 'maintaining social stability,' which was directly related to GDP growth. There had not been much attention paid to this issue in the discussions around the aforementioned macro-economic policies. In the 1980s hundreds of millions of excess rural labor had been released into market by the reform. Then in the 1990s as many as 30 million stateowned employees were laid-off on a large scale by another round of reform. Adding to that, population growth would bring about 10 million new labors every year, which put an enormous pressure on employment market. In case annual GDP growth was lower than 7\% in China,

\footnotetext{
${ }^{16}$ Joint Survey Team of Henan Academy of Social Science and Henan Petition Bureau, ‘关于 当前农村社会稳定问题的调查 (Survey Regarding the Present Rural Social Stability)’ 调研世 界 (The World of Survey and Research), 1999(1).
} 
there would be less than 8 million new employment opportunities. And the contradiction arising from the pressure of workers seeking employment with a shortfall new job supply would become dangerous. During the 1990s, mass incidents in the society sharply increased to a scale of tens of thousands every year. The situation for social stability overall was extremely severe. At that time, the idea of China Collapse became popular in the West. ${ }^{17}$ However, Bill Clinton who became U.S. president in 1993 adopted the 'China engagement' policy that was quite different from that kind of discourse.

But that buzzword did not last long. With a decade of growth driven by public debt since 1998 as well as its accession to the WTO in 2001 that brought in foreign investments, China had by 2008 when the financial crisis happened in U.S.A. already become the world's top country in foreign exchange reserve and second largest holder of U.S. Treasury bonds. During that same period, those western politicians and mainstream media who prophesized the collapse of China in the 1990s now changed their tune to the 'China Threat' hype.

It was in 2008 when the Wall Street financial tsunami gave rise to a global crisis that many Chinese began to realize China had already reached the monumental turning point ten years ago in 1997-1998 from over demand to oversupply. It was a decade of bidding farewell to shortfall and saying hello to excess in supply. It would be hard not to associate this ten-year period with the former after the 1988 economic crisis wherein the condition was that of a severe shortfall.

The word that scared the people in 1988-1998 was 'inflation'. Five years afterwards what described China's macro-economic trend had quietly switched to a term common folks would be hard put to it to understand: deflation.

During the economic trough from 1998 to 2002, the troika pulling the economy run out of steam, exposing with unprecedented clarity the contradiction between supply and demand. The first of the troika was domestic demand. Sale of general consumer goods became sluggish. (The wave of high-priced consumer goods such as cars and real

\footnotetext{
${ }^{17}$ When 'China collapse' was a buzzword in the West, a Chinese writer Wang Lixiong wrote a political fantasy fiction The Yellow Peril, which became a best-seller in early 1990s in the U.S.A., with 11 reprints.
} 
estate was yet to arrive.) Moreover, the industrialization reforms of education, health care and housing that were intended to drive domestic demand had the reverse effect of increasing people's level of savings with anticipation of future expenditures, hence further suppressing the consumption at the present. The second in the troika was investment. Indeed investments had stimulated rapid economic growth since 1992. Yet with tougher economic regulation in 1996 it became dampened. The third was foreign demand. China's manufactured goods export in 1978 had already accounted for $45.2 \%$ of total export. In a period of thirty years since 1949 , China was already able to export more than primary products. By 1997, that percentage increased to $86.9 \%$. In that year the total export amounted to US\$ 182.7 billion, 158.8 billion of which were manufactured goods. ${ }^{18}$ That meant it took China just another 20 years to complete the domestic expansion of capital and the preliminary adjustment of its export structure.

Yet this monumental structural change of the economy would inevitably bring corresponding structural change in economic crises. Not only was China's economy more vulnerable to external economic volatility, it also became increasingly affected by financial globalization.

Justin Lin Yifu proposed in 1999 the notion of a 'vicious cycle under the condition of double over-capacity' based on neoclassical economic theories. It well explained the swift absorption of China under pressure of over-capacity into globalization in a world which was already troubled by over-capacity in a very 'classical' sense.

Wang Jian, who put forward in 1988 the strategic formulation of 'great international circle', summarized China's opening to the world over the previous 30 years into three phases in an essay (see below column). The first phase was the 1980s during which China relied on foreign funds. The second was the 1990s during which the reliance switched from foreign funds to overseas markets. The third was the period after 2000 wherein the reliance turned towards international financial market under the context of globalization.

${ }^{18} \mathrm{Li}$ Jingzhi (李景治) \& Pu Guoliang (蒲国良), 社会主义建设理论与实践 (Socialist Construction: Theory and Practice). China Renmin University Press, 2003. 
Given that the central government was the dominating power in financial capital, the above-mentioned reliance on international finance was manifested mostly at the state level. At regional level, it still relied on foreign funds and the overseas market.

\section{Box 6: Three Phases in China's Opening to the World over Thirty Years}

From the perspective of the motivation to open to outside, China's Reform and Opening Up in the last thirty years went through three phases. The first phase was the 1980s in which China had to rely on foreign funds. That was the reason why I had envisaged the economic development strategy of 'the Great International Cycle', which meant taking the opportunity of industrial upgrade in Japan and Asia's Four Little Dragons, and making use of foreign capital to develop laborintensive products export in coastal regions. Then with the foreign reserves earned we exchanged for capital goods from the international market so as to look after at the same time the relocation of rural labor and the reconstruction/upgrading of heavy industries.

The second phase was the 1990s. Following the progress of China's reform and the in-take of large amounts of foreign capital, industrial capability and savings were both gradually consolidated. In 1991 a positive deposit differential in the banking system had appeared for the first time. The overall savings rate grew from $33 \%$ on average in the 1980 s to more than $40 \%$ in early 1990s. By mid 1990s, the reform had entered into the property rights stage, followed by a widening income gap. A fundamental change took place in the domestic supply and demand structure. Over-supply began to appear. Economic growth became increasingly reliant on export demand. As a result, the needs in opening up changed from reliance on foreign funds to reliance on overseas markets. Since the turn of the new century, under the context of globalization, export expanded rapidly and the scale of foreign capital being utilized continued to increase. Adding to that, the inflow of international hot money expanded the foreign currency reserves rapidly. Over the last 7 years the annual increase was on average US\$200 billion. By the end of 2007 it had reached US\$ 1.53 trillion, and firmly stayed in top position worldwide since 2005 . Given that China's capital market was 
not opened and the Renminbi was not internationalized, that enormous foreign reserve asset could only be invested in foreign markets. Therefore the need in opening to the outside changed again, from reliance on overseas markets to reliance on the international financial market.

From reliance on funds to reliance on markets then to finance, it reflected the transformation of China's mode of articulation with the global economy. At present, we have reliance on all three realms, with the focus shifting somewhat at different stages of economic development.

Source: Wang Jian, “关于设立“珠三角金融特区”的构想 (The Conception of Setting Up the 'Pearl River Delta Special Financial Zone')' 中国宏观经济信息网 (China Macro-economic Information), 4-8-2008. http://www.macrochina.com.cn/zhtg/200808040 91350.shtml.

By the twenty-first century, China's opening up took a step deeper into the new circle of international economy dominated by U.S. financial capital, namely, financial globalization.

As discussed in previous chapter, China had implemented the exchange rate reform in 1994 under serious pressure of current account deficit with a one-time currency depreciation of more than $50 \%$, as a means to raise export competitiveness and attract foreign funds inflow. With rapid growth in export and controlled capital account, mounting stock of foreign currency reserve was rendered into expansion of domestic money supply. With this kind of 'hedging', China was able to be sheltered to some extent from international financial risk.

Generally speaking, in this round of international transfer of industries led by transnational companies under the pressure of global overcapacity, those being transferred outward from developed countries like the U.S. included not only labor intensive industries but also capitalintensive or technology-intensive industries, a key feature unseen in previous rounds. Capital and technology-intensive industries had more stringent requirements on capital, cost of external financing as well as efficiency. Therefore those developing countries received industry transfer became more dependent on foreign financing. When these industries began to move out, most Asian countries experienced financial 
crisis. Even though China's financial development level was much lower than the U.S, it emerged as the most stable financial market in the Asia at that time. Besides, Renminbi exchange rate was appreciating consistently and therefore there was positive anticipation that China might gradually open up foreign exchange control. As a result, not only the U.S.A. transferred industries to China, other Asian countries also followed. China gradually rose as the main receptor of global industrial transfer. ${ }^{19}$

Nevertheless, to have a more comprehensive understanding on a phenomenon, it is preferable to make references to different evaluations.

From the perspective of Samir Amin's "dependency theory", what China's economy had completed in the 1990s, under the pressure of serious domestic and foreign debt crises, was a historical transformation from "de-linking" to "re-linking". The policies being adopted and the economic phenomena that had stemmed from it were also similar to those in other developing countries in general. Among the policies in response to the 1990s crises, the financial policy of 'raising interest rate and lowering exchange rate' had indeed transformed the economic development environment. On one side the high capital cost within the country was squeezing the profit margin of enterprises oriented towards domestic demand. What it facilitated was China's export economy that generated foreign reserves. On the other side, it matched precisely with the strategy of transnational corporations seeking profit by making use of "low interest rate + high currency value" combination. In the stage of so-called financial deepening, transnational corporations were motivated by the gains through this international capital circulation. What followed then was a new round of international industrial capital at the turn of the new century. That was also the reason why China all of a sudden became the number one recipient country worldwide of foreign direct investments (FDI) during 1998-2008 between the two imported crises. It was in this decade that many of the Fortune 500 companies made their presence in China. US transnational companies took the lead in almost all of the strategic industries. Thanks to these investments in

\footnotetext{
${ }^{19} \mathrm{Li}$ Xingong (李新功), “美元霸权、金融发展差异与货币体系错配下中美经济失衡及调 整 (Dollar Hegemony, Financial Development Differences and Monetary Systems Mismatch: Economic Imbalance and Adjustments in China and the U.S.A.)' 现代经济探讨 (Modern Economy Inquiry), 2009(9).
} 
China their average annual rate of return went from under $20 \%$ to more than $30 \%$. The industrial transfer out of the U.S. was detrimental to US industrial workers. Yet the rise in overseas capital returns stimulated Wall Street's prosperity to a large extent as the Dow Jones Industrial Average Index was breaking historical record year after year.

The above discussion of the transformation of China's domestic and foreign policies since the 1990s is an objective and factual description. However, it may help to unveil a part of the true face behind the so-called 'G2' or 'Chimerica', as some have put forward.

Under the impact of the above factors in the 1990s, China's principal momentum in opening up changed at the turn of the century from the force of domestic over-capacity to the pull of external demand. During the same period, the substance of the export economy mostly located in coastal regions also underwent transformation-from traditional general trade of manufacturing processing where profits came mainly from internal allocation inside localized industries, to a new type of processing trade where profits of branding and selling were mostly realized in foreign markets and high-tech industrial processing where both raw material supply and final market were outside of China.

Thereupon, Chinese enterprises and labors in general could only share a very small part of the total profits realized in the whole industrial chain. Worse still, the right of pricing in raw material markets and the power of institutional arrangement in international trade were not in China's hands. That effectively constituted the condition by which foreign interest blocs could constrain and shape China's institutional transition as well as relevant intellectual thinking.

Import was always coupled with export. This change in the mechanism of opening up started with the 1998 imported crisis caused by external financial crisis (the 1997 Southeast Asian financial crisis generated by international hot money flow) which forced China to urgently open its economy still at the stage of industrial capitalism.

On that basis, we propose a hypothesis that: it was because China and the West were situated in two different phases of capitalist civilizationrespectively industrial capitalism and financial capitalism-that China would have an induced change in the content of its export structure. 
Before 1998, China was still in the industrial capital expansion stage propelled by structural adjustments, which was completely different from the USA. In the latter case, the virtual expansion of financial capital took place simultaneously with outward transfer of industry. The USA recorded long term trade deficits while capital account surplus was growing. Back then China's economy was yet to be highly dependent on foreign markets. Domestic and foreign markets mainly served China's industrial capital expansion. They were mutually replaceable. Large increases in import were usually offset by large decreases in export. As seen in graph 4-6, the import growth rate and export growth rate curves went in opposite directions most of the time during 1980-1990. The turning point was the 1997 Southeast Asian crisis when public debt driven investments became the key impetus of growth.

Figure 8 shows a high correlation between import growth rates and China's economic situation. For example, the two economic surges in 1982-1985 and 1992-1993, caused by domestic industrial capital expansions led to drastic increases of import while export over the same periods decreased. Furthermore changes in export were more sensitive to stimulating policies. For example, there were high export growth rates in 1987 and 1994 responding to policy adjustments on trade. Yet after

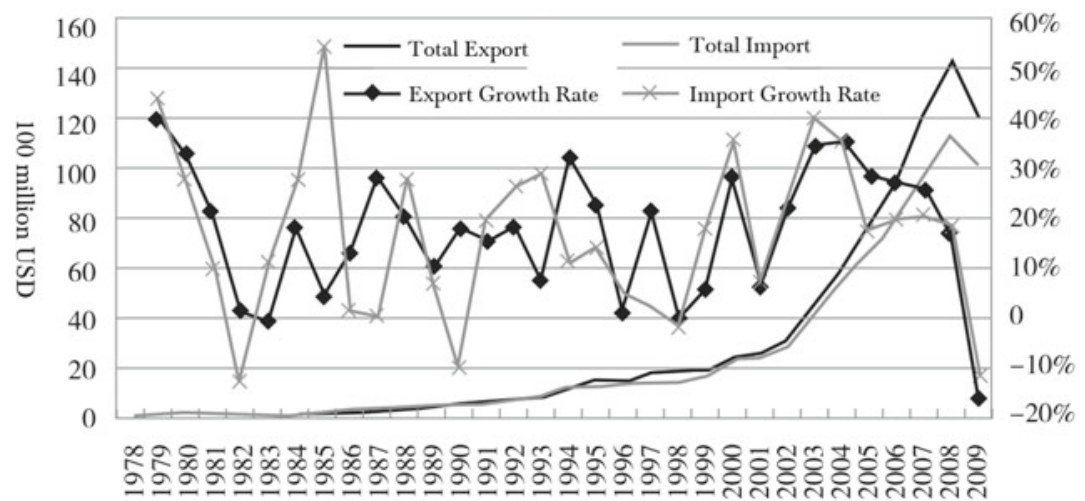

Fig. 8 Changes in China's trade structure since 1978 (Data source: China Statistical Yearbooks) 
1998, import and export trends went almost hand in hand in the same direction.

While the world economy was emerging out of the slump from 2002 until 2008 before the Wall Street financial crisis, China shifted towards the trade model of manufacture processing wherein both ends of trade (raw material supplies and product markets) were on the outside. Hence import and export were rising simultaneously.

As China's participation in international trade was largely in the form of manufacture processing after 2002, the volume of general trade (import and export) accounted for around $40-50 \%$ out of the total trade volume.

When foreign investments entered into China in the 1980s, they were interested in the potential of China's enormous consumption market. At that time the principal force in creating export and foreign exchange reserve were domestic enterprises. By the 1990s when China sought to release excess capacity into international market, even though the proportion of export by foreign-owned enterprises had grown substantially it was still lower than domestic enterprises. However, since 2000 foreign owned enterprises accounted for more than 50\% of China's total import and export trade. The share of foreign-owned enterprises in export accounted for $52.2 \%$ in $2002,58.2 \%$ in 2006 and over $60 \%$ in 2011. In the South Suzhou region where the structure of manufacturing had already been shaped to facilitate industrial capital in the Yangtze delta area, the characteristics of export-oriented economy were even more pronounced. The proportion of import and export by foreign enterprises exceeded $70 \%$ (Figs. 9 and 10).

China's total import and export in 2001, the year of its accession to the WTO, valued at US\$ 509.8 billion. Seven years later in 2008 when the Wall Street financial crisis broke out, the total value already grew up by five times to US\$ 2.56 trillion. The average annual growth rate over these 7 years was as high as $26.1 \%$. Meanwhile, China's share intotal world trade rose from 4.06 to $7.88 \%$.

China's dependency on international trade maintained at around $70 \%$ for a relatively long period. It relied on overseas demand to drive its annual GDP growth up to double digit and was increasingly blended into the global capital regime led by the U.S.A. at accelerating pace of 


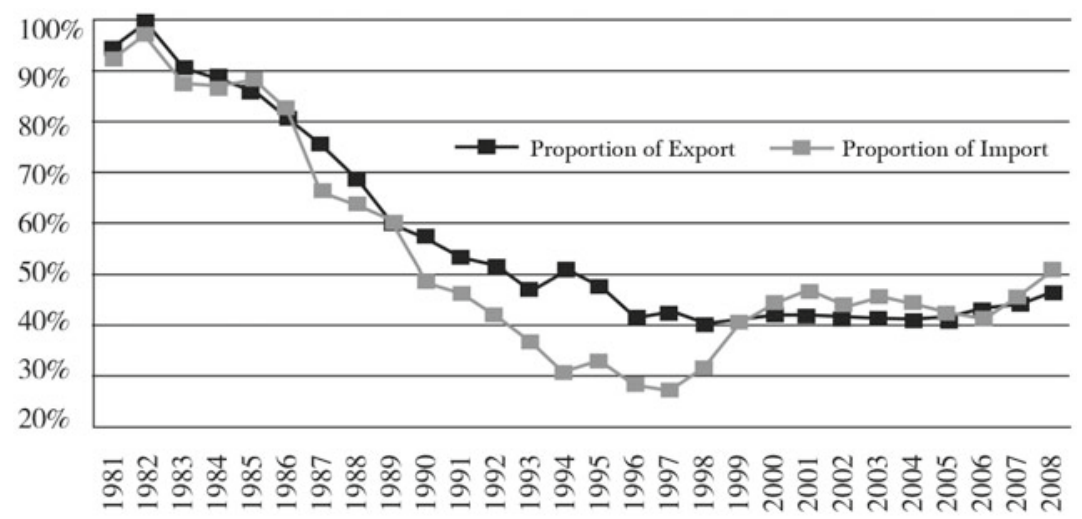

Fig. 9 Proportions of general trading in China's total import/export (Data source: China Statistical Yearbooks)

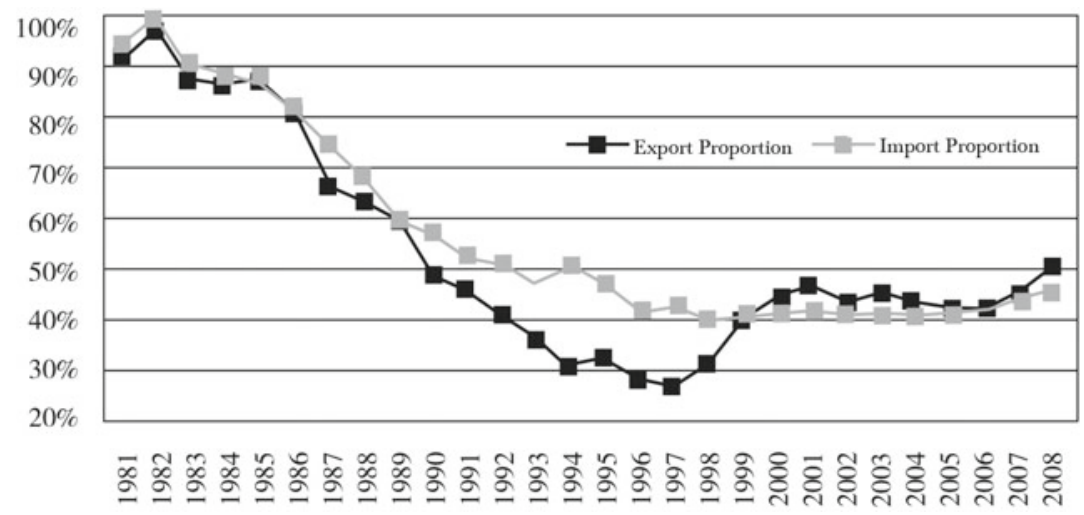

Fig. 10 Shares of foreign enterprises import/export in China and Jiangsu Province (Data source: China Statistical Yearbooks)

financial deepening. Then the Wall Street financial crisis, much more violent and with a more profound impact than the Asian crisis ten years ago, broke out. 


\section{$4 \quad$ The Ninth Crisis: Policies Responding to the 2008 Financial Crisis and Impact}

Since the 1980s the capitalist economy in the West was "upgraded" to financial capitalism led by the USA. In a short span of 20 years the U.S. capital market already created more than 2,000 types of derivatives, thereby promoting the low cost global expansion of the financial economy. Simultaneous to that, the enormous institutional cost corresponding to this development was inevitably accumulating while astronomical amount of financial capital marched into the brave new world of the virtual economy. That accumulated cost manifested itself continuously as a series of financial crises that moved gradually from the periphery (Latin America, East Asia etc.) towards the core (the USA where financial speculation was most intensive) in the world financial system.

In the summer of 2008, with the deterioration of the Subprime Crisis in the previous year, Lehmann Brothers, the fourth largest investment bank in Wall Street filed for Chapter 11 bankruptcy. The two largest mortgage loan companies Fannie Mae and Freddie Mac as well as the largest insurance group AIG were temporarily "nationalized". The curtain was drawn open for the global economic crisis caused by the Wall Street financial tsunami.

The rest was history most people are familiar with. However what many around the world do not know is that during this advanced phase of capitalism, financial capital with its dominating position in global economy and by the command of the country holding the unipolar hegemony, was capable of transferring the institutional cost outwards and downwards. In addition, it also held the institutional power (a soft power constructed to protect this international politico-economic order) and discursive power-a smart power working hand in hand with the former. They were mutually dependent, spreading worldwide in the company of globalization and becoming the root of the general aphasia among intellectuals in developing countries who lost sight of their responsibility of localized knowledge production. While the crises were moving from the periphery toward the core, these intellectuals were busy at parrot talking 
and lost the ability to understand what was happening in their own countries.

The positive experiences that China had gained in dealing with crises also fell into oblivion amidst that aphasia.

\section{China's Domestic Situation Before the Crisis}

As a response to the crisis in 1997-1998, the large scale public debtdriven investments aiming at spurring domestic demands had been mostly put into infrastructure construction and improvement, thus facilitating China with the hardware to further integrate with the global economy. Since the second half of 2002, with the revival of global economy and the re-setting of international industrial layout directed by the advanced countries, China became the most attractive country for foreign direct investments, given that its infrastructure was in a much better shape than developing countries in general. The impetus led to a new wave of high speed economic growth in China.

As compared to the past, before the eruption of the 2008 crisis China's economy manifested some new features in terms of the development mode and structure.

\section{China's Economy was Further Integrated into the Great Global Economic Circulation Dominated by the USA}

Around the turn of the twenty-first century, global financial capital developed further into excess and over expansion, driving advanced countries to undertake structural adjustments and upgrade traditional industries to information industry. Following that, the international industrial configuration also saw profound changes. 


\section{Box 7: International Industrial Transfer in the Twentieth Century}

International industrial transfer in the twentieth century can generally be summarized into three waves.

The first wave took place in the mid-twentieth century, as a consequence of the seismic shift in the centuries-long western imperialist geo-political configuration, a shift brought about by the Second World War caused by the power collision during industrial capitalist expansion. The two emerging super powers, the U.S.A. and U.S.S.R., in order to consolidate their geo-political controls, both deployed industrial exports in a "flying-goose formation"-the U.S. towards Western Europe and Japan, and the U.S.S.R. towards Eastern Europe and China. The difference between the two was that, the U.S., having completed the outward industrial transfer to facilitate its geo-political strategy, took the lead into financial capitalist expansion, while the USSR's outward industrial transfer was halted midway due to its controversies over sovereignty with China, foreshadowing its subsequent disintegration.

The second wave of industrial transfer took place in the 1960s. In general it could be regarded as the process in which the spillover effect of manufacturing capital resulted in rising cost of production factors, thereby driving developed countries to transfer manufacturing outwards. With the development of science and technology, labor cost in developed countries continued to inflate. Furthermore, given the increasingly intensified labor and capital conflict that was inevitable in industrial capitalism, the world then saw a new wave of global industrial structure adjustments, with developed countries in the lead. Labor-intensive industries were transferred from developed to developing countries, leaving the former to focus on development of technology and capital intensive industries, realizing upgrades in economic structure.

In the 1960s and 1970s when the Cold War still at its height, those countries and in the Western camp and along the frontier had been the first to receive this round of industrial transfer. As their societies and cultures were somehow similar, the process was smooth with little institutional friction. Likewise, Korea, Taiwan, Singapore and Hong Kong-countries and regions that shared Confucian civilizationreceived industrial transferal from Japan to launch 'export-oriented' strategy, putting priority on labor-intensive processing manufacturing. 
In a short span of time they were able to realize economic upsurge and referred to as 'Asia's four little dragons'.

Since the four little dragons were small geographically, the spillover effect of receiving capital from international industrial transfer rapidly led to resources re-pricing within their realm. To secure profit margins, capitals seeking optimal return then flowed into countries and regions around the four little dragons, where the prices of essential factors such as land, resources and labor force were still relatively low. The Asia's 'four little tigers' thereupon developed rapidly.

China resumed diplomatic ties with the West in 1972. Simultaneously, the second round of opening up had started. Western equipments were brought in on a large scale to adjust its industrial structure. It was against this backdrop the 'processing manufacturing and repayment trading' model in Pearl River delta region emerged while the cities along the Yangtze River specified in heavy and chemical industries started to make structural adjustment.

In early 1970s, after Mao Zedong accepted the military assessment that a new world war would not break out within 20 years, China resumed diplomatic relations with Europe, the USA and Japan. Western capital was thereupon introduced into industrial cities in coastal regions where industries were more concentrated. In mid to late 1970s, the international situation had progressed in a direction favorable to third world countries with regard to receiving industrial transfer. At the same time, the tension in China's eastern and southern coastal region (due to the antagonism with Taiwan) had also eased up. Guangdong province which previously had a relatively weak industrial base was able to rapidly accumulate domestic and foreign resources with the help of policies favoritism from the central government and the advantage of proximity to Hong Kong and Macau, from which labor-intensive industry was transferred into the province. An exogenous industrial structure corresponding to the process gradually took shape. Guangdong rapidly developed into an economically prominent region, drawing the curtain of China's third opening up with local governments in the lead. (The first opening up referred to the 1950 s aiming at primitive capital accumulation, the second in early 1970s attempting to adjust industrial structure. Both had been executed in the name of the state. The only difference was that in 
the first round the foreign capital came from the USSR while in the second round Western countries and Japan.)*

In Asia, the flying goose formation industrial structure with Japan at the tip stabilized gradually. Japan located at the apex of East Asia's economic hierarchy exported top-end technological products to East Asian countries and bought relatively low-end products from the latter which received Japan's obsolete industries. The reliance of those latedeveloping countries on Japan's high-end products and on Japan's market for selling their low-end products constituted Japan's structural support on East Asian economic development.**

The international industrial transfer taking place around the turn of the twenty-first century can be regarded as the third wave, largely the outcome of the rise of IT industry. Since the 1980s when the international political situation eased up, a large number of military technologies achieved in advanced countries during the Cold War were converted to civilian use, giving impetus to an industrial upgrade with the knowledge economy as its base. It continued to be the driving force for developed countries' outward industrial transfer (see next column).

*Wen Tiejun, ‘新中国三次对外开放的成本与收益'(New China's Three Rounds of Opening Up: Costs and Benefits), in 我们到底 要什么(What In Fact Do We Want). Huaxia Publishing House, 2004; Wen Tiejun et el, 广东省产业结构和发展战略调整研究课 题报告 (Report on Guangdong Province's Industrial Structure and Development Strategy Adjustments), 2008.

**Ju Hailong(鞠海龙), ‘破日本雁阵 中国一东盟布新局’ (Breaking Japan's Flying Goose Formation: the New China-ASEAN Layout), 时 代周报(Time Weekly), 23-4-2009.

The USSR disintegrated in the 1990s and the post-cold war world turned into an arena of globalized competition dominated by financial capital. The approach to make profits by the financial empire, given its unipolar hegemony, underwent a fundamental change. It increasingly relied on inflow of capital to drive up the capital markets. Financial capital seeking liquidity for profit making in the virtual economy was increasingly alienated from industrial capital. Transnational corporations transferred processing manufacturing segments to developing countries. 
This round of transfer had different features. Labor-intensive industries that no longer had comparative advantage in competition in developed societies continued to transfer outward to developing countries. At the same time technology and capital intensive industries began to be transferred. Apart from the raw materials industry, processing and general manufacturing, now service industry and high-tech industries became the focus, such as finance and insurance, trading services as well as capital intensive heavy industries including steel, automobile, petroleum and chemical industries, etc.

This round of industrial transfer was generally referred to as a revamping of global industrial capital configuration. Yet it was still a two-way selective exchange process. Advanced countries made the strategic adjustments of keeping the research and development sector and moving the production sector closer to the markets, while late-developed countries opened their markets for capital and technology in order to accelerate domestic industrial development.

The motive for this new round of industrial transfer was consistent with the global geo-political strategies of developed countries since colonialist expansion began 500 years ago. Take heavy and chemical industries as example. Developed countries markets had reached full capacity and the profitability was declining whereas in East Asia, emerging industrialized countries got stronger in manufacturing. The profit rates of heavy and chemical industries were consistently rising. Some even towered over other sectors. Therefore transnational collaboration with Chinese enterprises in heavy and chemical industries was imperative for competing in this emerging market. Japanese and Korean heavy and chemical industries had developed under trade protectionism. Their target markets were the downstream export-oriented industries. Given their proximity to China, over the past two decades their upstream industries had already enjoyed the fruits of China's development in light industry. Yet as a whole, they were only second class in the world (excepting Japanese automobiles). The first class players were still European and US heavy and chemical enterprises. Now, those Fortune 500 giants made high profile presence in China to join forces with local enterprises. It could possibly crowd out similar Japanese and Korean products that had relatively higher production factor prices. That was the outcome 
of global industrial chain revamping since 2002 as global economy was booming. The capital bubble was growing while the cost of production factors kept rising. The reshaping of global industrial configuration was an interaction of colliding forces.

\section{US Dot-Com Bubble and FDI Flooding into China}

China became one of the largest FDI recipients in the world may be contextualized in the rise of IT industry in the US.

\section{Box 8: US IT Industry's Roller-Coaster Ride: 1995-2001}

The predecessor of contemporary information technology was intelligence technology, originated at the end of the nineteenth century and widely applied during the Cold War (1).

In 1994, the Mosaic browser and the World Wide Web had attracted the public's attention. At first people simply took notice of internet's free publication and real time information from around the world. Gradually people began to adapt to two-way online communication, and further started using internet as the medium for electronic commerce and worldwide instant communication.

This new media technology that could contact millions of people around the world quickly at low cost and could connect buyers and sellers as well as advertisers and consumers immediately, brought changes to traditional commercial creeds such as advertising, mail order and customer relationship management. The internet brought about all kinds of new business models that were impossible just a few years back, thus attracting venture fund investments.

Netscape was listed on the stock market on 9 August, 1995, officially announcing the arrival of internet era and later leading to internet stock bubble as well as over-investments in optical fiber cable. As Netscape's former CEO Barksdale had said, 'We have initiated the internet bubble.'

A typical "dot.com" business model relied on a sustaining net effect, and for that it had to pay the price of running at a net loss to acquire market share. The company hoped to build sufficient brand recognition in order to gain return on subsequent service provision. The slogan of 
'grow big fast' explained this strategy. During the period of running at a loss, the company would have to rely on venture funds and fund-raising at initial public offering (IPO). The novelty of these stocks as well as the inestimable value of the company pushed the price of many stocks to dumb-founded highs, and brought huge wealth on paper to the primary shareholders.

A small number of founders had acquired enormous wealth upon IPO of their companies during the early stage of the Dot Com bubble. These early successes made the speculation even more active. During the bloom it had attracted unprecedented number of individual investors. The media reported cases where people would resign from their jobs to focus on stock speculation.

As Su Guangping said, “The stock market's sensitiveness, amplification and feedback towards the economy have provided sufficient room for speculation. In stock market, as long as there are good stories there would be people speculating and believing. The concepts of advanced information technology, particularly the internet, were novel and noncomparable, making them ideal stories for speculators. Hence there were people suggesting that ' 3 years of internet economy is equivalent to 70 years of industrial economy' and some even claimed that 'the internet has subverted all economic rules'. Spurred on by the lead of venture funds, capital from domestic and foreign sources in a short span of time swarmed the internet realm in which the profit model was obscure. At the same time it also drove up the stock price of other IT enterprises. More and more people were being attracted to enter the market with anticipation of future rise, thereby pushing up the price further in a spiral. An exuberant bull market therefore took shape."

In various stock markets in Europe, America and Asia, the price of technology and internet related company stocks rapidly rose. On 10 March 2000 the NASDAQ index had reached the peak with the day high of 5048.62 .

Yet an over-inflated stock market bubble could not possibly be sustained. Once the fact of continued losses of internet businesses set up the general anticipation of going short, the unrealistic stock price turned south and fall, resulting in a market crash. 
The crash amplified the recession in real economy. The internet bubble bust wiped away around US\$ 5 trillion of market value from technology companies between March 2000 and October 2002.

Some suggested that the internet bubble's burst stimulated the emergence of housing bubble in the USA. Yale University's economist Robert Schiller said in 2005, "Once stocks fell, real estate became the primary outlet for the speculative frenzy that the stock market had unleashed. Where else could plungers apply their newly acquired trading talents? The materialistic display of the big house also has become a slave to the bruised egos of disappointed stock investors. These days, the only thing that comes close to real estate as a national obsession is poker" (2).

References:

(1) http://baike.baidu.com/view/4402048.htm.

(2) Quoted by Jonathan Laing, 'The Bubble's New Home,' Wall Street Journal, 20-6-2005.

Source: http://baike.baidu.com/view/780.htm?fr=aladdin, Su Guangping(苏广平), '关于IT经济泡沫的反思(Reflections on the IT Bubble),' 2004-7-21, http://www.eepw.com.cn/article/27.htm.

The U.S. internet bubble went bust in 2001. Even though it was no more than one of the manifestations of economic cycle in the phase of capitalism civilization, "from a historical perspective, the prosperity of internet economy could be regarded as similar to other technological prosperities, including the railroad in the 1840s, the automobile and radio in the 1920s, the transistor in the 1950s, timesharing computer systems in the 1960s as well as personal computers and biotechnology in early 1980 s" $^{20}$ It did in fact give Asian countries an opportunity to go against the trend and take a ride on the IT express. ${ }^{21}$

The reason was before the dot-com bubble bust, overinvestment into the real economy had been frenzied. One typical case was information network construction. During the time when the internet bubble expanded, the growth of internet communication capacity was forecasted

\footnotetext{
${ }^{20} \mathrm{http}: / /$ baike.baidu.com/view/780.htm?fr=aladdin.

${ }^{21}$ Thomas Friedman, The World is Flat: A Brief History of the Twenty-first Century. London: Penguin Books, 2006.
} 
to double every 100 days. The funds invested into networks in 1999 had reached US\$ 100 billion, exceeding the total in the previous 15 years. Between 1998 and 2001, the number of underground fiber-optic cables laid increased by 5 times. By the time the internet bubble collapsed, the length of underground optical fibers in the U.S. was around 39 million miles. $^{22}$

Prosperity in the stock market meant that the invested funds were cost-free. In 5 to 6 years, communication companies had invested a total of around US\$ 1 trillion to lay all kinds of optical cables, and no one had ever questioned the future demand (Friedman 2006).

Adding to that, technological advancement raised the communication capacity of optical cable. The overall communication capability of U.S. fiber-optic network had increased by tens of times in the short span of a few years. Yet the growth in demand was lagging behind. Even during the early period of high speed development, the growth in internet communication capacity was only doubling every year. The rate of growth in the later period was even lower. In 2002 the growth in internet capacity worldwide was less than $40 \%$ ( $\mathrm{Su} 2004$ ).

Another typical case was the semi-conductor industry. At the end of the last century, given that the semi-conductor market had grown substantially due to the rapid expansion of electronic equipment market, various semi-conductor manufacturers competed to invest enormous amounts into building production lines for new generation chips. First they competed in the 8 inch production line that cost at US\$ 1 billion each, then 12 inch production line at US\$ 2 to 3 billion (ibid.).

Such overinvestment was of course highly risky from economic perspective. Yet from technological perspective, "they also often do drive innovation faster and faster, and the sheer overcapacity that they spurwhether it is in railroad lines or automobiles — can create its own positive consequences...Unlike other forms of Internet overinvestment, it was permanent: Once the fiber cables were laid, no one was going to dig them up and thereby eliminate the overcapacity. So when the telecom companies went bankrupt, the banks took them over and then sold their fiber

\footnotetext{
${ }^{22} \mathrm{Su}$ Guangping, 'Reflections on the IT Bubble,' 2004-7-21, http://www.eepw.com.cn/article/
} 27.htm. 
cables for ten cents on the dollar to new companies, which continued to operate them, which they could do profitably, having bought them in a fire sale....[T] he capacity of all the already installed fiber cables just keeps growing, making it cheaper and easier to transmit voices and data every year to any part of the world" (Friedman 2006:71-75).

It was precisely these internet infrastructure built during the internet bubble period with enormous amounts of investments that created a big market for all kinds of virtual space based on that infrastructure. It narrowed the digital gap between developed and developing countries as well as the industrial gap between them. It could be said that the speculative funds invested during the peak of the internet bubble spilt over to other industries and eventually integrated with the real estate sector, to a very large extent raising the operating costs of real industries in those countries at the internet bubble core, forcing industrial capital in these countries to transfer outward to developing countries. And the narrowed digital gap strengthened the feasibility of this move economically and technologically.

"Off-shoring" appeared in accordance with this. That and "service outsourcing" together would explain the changes in global FDI flows since 2001. Similar to the process in the 1960s when manufacturing companies in developed countries out-sourced part of their operations off-shore, the rapid development of offshore service outsourcing in the past decade has become another characteristic of service outsourcing. According to estimations, in 2001 the total market for off-shore service export had amounted to roughly US\$32 billion. The principal service providers were Ireland, India, Canada and Israel. Based on statistics from International Data Corporation, global expenditures on service outsourcing increased from US\$ 99 billion in 1998 to US\$ 150 billion in 2001 , then to US\$ 300 billion in 2004, with a compound annual growth rate of $12.2 \%$. The rate for Asian regions was $15.1 \%$. Among this, the market for software foreign out-sourcing grew by $29.2 \%$. Offshore services related to IT had the fastest growth rate. Based on estimation of UNCTAD, the offshore out-sourcing driven by IT sector was 
around US\$ 1.3 billion in 2002, accounting for $1 \%$ of total global outsourcing. $^{23}$

From 2001 to 2003, global FDI declined from the previous year by $41.1 \%, 17 \%$ and $17.6 \%$ respectively. Examining global FDI flows by region would give even more meaningful findings.

FDI into developed countries had declined in 2003 from previous year by $25 \%$ overall, amounting to US\$ 367 billion. Of this, FDI into the USA decreased by 53\%, from US\$ 63 billion to US\$ 30 billion, the lowest level in 12 years. The total flow into the EU dropped by $21 \%$ to US\$ 295 billion.

In that same year, the FDI outflow from developed countries went up by $4 \%$, amounting to US $\$ 570$ billion. Of this, the outflow from the USA grew by almost 1/3, reaching US\$ 152 billion. Next were Luxemburg (mainly investments in transit), France and U.K. The FDI outflow from the United States increased while inflow decreased. The net was an unprecedented outflow of US\$ 122 billion.

The reduction in FDI to developed countries did not flow evenly to developing countries.

FDI inflows to Central Europe and Eastern Europe were weak in 2003, decreasing from US\$ 31 billion to US\$ 21 billion while recovery appeared in developing countries as a whole, with FDI inflow growing by 9\% to US\$ 172 billion. Of this, Africa, Asia and Pacific region showed increases whereas Latin America experienced sustained decline (Table 4).

FDI inflows to Asian regions increased in 2003 from previous year by $14 \%$, reaching US\$ 107 billion. Of this, inflows increases were seen in 34 economies and decreases in 21 economies. The inflow was concentrated in Northeast Asia and in service industries. China became the second largest FDI recipient, next only to Luxemburg (which had mainly investments in transit, therefore not comparable). The amount was US\$ 53.51 billion. The flow into Southeast Asia was increased by $27 \%$, amounting to US\$ 19 billion. South Asia had US\$ 6 billion, with a growth of $34 \%$ while central Asia had US\$ 6.1 billion, a growth of 35\% and West Asia

\footnotetext{
${ }^{23}$ Zou Quansheng (邹全胜) \& 王莹 (Wang Ying), ‘服务外包: 理论与经验分析 (Service Outsourcing: Theoretical and Empirical Analysis), 国际贸易问题 (Journal of International Trade), 2006(05), pp 54-61.
} 
Table 4 FDI In-flows to regions around the World 1992-2003 (Unit: US\$ billion)

\begin{tabular}{|c|c|c|c|c|c|c|c|}
\hline Region/Country & $\begin{array}{l}1992- \\
1997 \\
\text { (annual } \\
\text { average) }\end{array}$ & 1998 & 1999 & 2000 & 2001 & 2002 & 2003 \\
\hline $\begin{array}{r}\text { Developed } \\
\text { countries }\end{array}$ & 180.8 & 472.5 & 828.4 & 1108 & 571.5 & 489.9 & 366.6 \\
\hline $\begin{array}{l}\text { Western } \\
\text { Europe }\end{array}$ & 100.8 & 263 & 500 & 697.4 & 368.8 & 380.2 & 310.2 \\
\hline Japan & 1.2 & 3.2 & 12.7 & 8.3 & 6.2 & 9.2 & 6.3 \\
\hline U.K. & 60.3 & 174.4 & 283.4 & 314 & 159.5 & 62.9 & 29.8 \\
\hline $\begin{array}{l}\text { Developing } \\
\text { economies }\end{array}$ & 118.6 & 194.1 & 231.9 & 252.5 & 219.7 & 157.6 & 172 \\
\hline Africa & 5.9 & 9.1 & 11.6 & 8.7 & 19.6 & 11.8 & 15 \\
\hline $\begin{array}{r}\text { Latin America } \\
\& \text { Caribbean }\end{array}$ & 38.2 & 82.5 & 107.4 & 97.5 & 88.1 & 51.4 & 49.7 \\
\hline Asia & 74.1 & 102.2 & 112.6 & 146.1 & 111.9 & 94.4 & 107.1 \\
\hline Pacific Region & 0.4 & 0.2 & 0.3 & 0.1 & 0.1 & 0.1 & 0.2 \\
\hline $\begin{array}{l}\text { Central and } \\
\text { Eastern } \\
\text { Europe }\end{array}$ & 11.5 & 24.3 & 26.5 & 27.5 & 26.4 & 31.2 & 21 \\
\hline Global & 310.9 & 690.9 & 1086.8 & 1388 & 817.6 & 678.8 & 559.6 \\
\hline
\end{tabular}

Source: Xin Jie (辛洁)，全球FD/向服务部门转移的趋势分析和对中国的政策建议 (Trend Analysis of Global FDI Shifts towards Service Sector and Policy Suggestions for China), Nankai University Master thesis, 2005

US\$ 4.1 Billion (14\%). The various Pacific Islands had US\$ 0.2 billion (details shown in the Table 5).

The cross-sectional statistics for 2003 provided a wealth of information. If the vertical data were added, it would be seen that China's FDI inflow changes showed a saddle-shaped trend: from 1998 it showed a sharp drop due to the East Asian crisis and 2001 marked the start of a rising trend coincidental with the year of U.S. dot-com bubble bust (Fig. 11).

Inflows of FDI to developed countries were mostly founded on investor's anticipation of high yield from the capital market whereas investments to China from developed countries mostly focused on the manufacturing sector, amounting to around $2 / 3$. FDI investment into China's secondary industries as a proportion of total FDI was consistently rising from 1999 to 2002, reaching $74.8 \%$. It remained stable at around $74 \%$ from then on to 2005 . Among secondary industries, FDI 
Table 5 China's actual use of foreign capital 1983-2012 (Unit: US\$ billion)

\begin{tabular}{|c|c|c|c|c|c|}
\hline Year & $\begin{array}{l}\text { Foreign } \\
\text { loans }\end{array}$ & $\begin{array}{l}\text { Foreign } \\
\text { direct } \\
\text { investments }\end{array}$ & $\begin{array}{l}\text { Other } \\
\text { foreign } \\
\text { investments }\end{array}$ & $\begin{array}{l}\text { FDI's } \\
\text { weight in } \\
\text { GDP (\%) }\end{array}$ & $\begin{array}{l}\text { Total } \\
\text { foreign } \\
\text { investment } \\
\text { actually } \\
\text { used }\end{array}$ \\
\hline 1983 & 1.07 & 0.92 & 0.28 & 0.3 & 2.27 \\
\hline 1984 & 1.29 & 1.42 & 0.16 & 0.5 & 2.87 \\
\hline 1985 & 2.51 & 1.96 & 0.30 & 0.6 & 4.77 \\
\hline 1986 & 5.01 & 2.24 & 0.37 & 0.8 & 7.62 \\
\hline 1987 & 5.81 & 2.31 & 0.33 & 0.7 & 8.45 \\
\hline 1988 & 6.49 & 3.19 & 0.55 & 0.8 & 10.23 \\
\hline 1989 & 6.29 & 3.39 & 0.38 & 0.8 & 10.06 \\
\hline 1990 & 6.53 & 3.49 & 0.27 & 0.9 & 10.29 \\
\hline 1991 & 6.89 & 4.37 & 0.30 & 1.1 & 11.56 \\
\hline 1992 & 7.91 & 11.01 & 0.28 & 2.3 & 19.20 \\
\hline 1993 & 11.19 & 27.51 & 0.26 & 4.5 & 38.96 \\
\hline 1994 & 9.26 & 33.77 & 0.18 & 6.0 & 43.21 \\
\hline 1995 & 10.33 & 37.52 & 0.29 & 5.2 & 48.14 \\
\hline 1996 & 12.67 & 41.73 & 0.41 & 4.9 & 54.81 \\
\hline 1997 & 12.02 & 45.26 & 7.13 & 4.8 & 64.41 \\
\hline 1998 & 11.00 & 45.46 & 2.09 & 4.5 & 58.55 \\
\hline 1999 & 10.21 & 40.32 & 2.13 & 3.7 & 52.66 \\
\hline 2000 & 10.00 & 40.72 & 8.64 & 3.4 & 59.36 \\
\hline 2001 & - & 46.88 & 2.79 & 3.5 & 49.67 \\
\hline 2002 & - & 52.74 & 2.27 & 3.6 & 55.01 \\
\hline 2003 & - & 53.51 & 2.64 & 3.3 & 56.15 \\
\hline 2004 & - & 60.63 & 3.44 & 3.1 & 64.07 \\
\hline 2005 & - & 603.3 & 3.48 & 2.7 & 63.81 \\
\hline 2006 & - & 63.02 & 4.06 & 2.4 & 67.08 \\
\hline 2007 & - & 74.77 & 3.57 & 2.3 & 78.34 \\
\hline 2008 & - & 92.40 & 2.86 & 2.1 & 95.26 \\
\hline 2009 & - & 90.03 & 1.77 & 1.8 & 91.80 \\
\hline 2010 & - & 105.73 & 3.09 & 1.8 & 108.82 \\
\hline 2011 & - & 116.01 & 1.69 & 1.6 & 117.70 \\
\hline 2012 & - & 111.72 & 1.58 & 1.4 & 113.30 \\
\hline
\end{tabular}

Data Source: edited from China Statistical Abstract 2013

was mostly concentrated on manufacturing. That had to do with China's abundant supply of low-cost labor and raw material. Manufacturing could provide long-term stable returns on investment. Furthermore, 


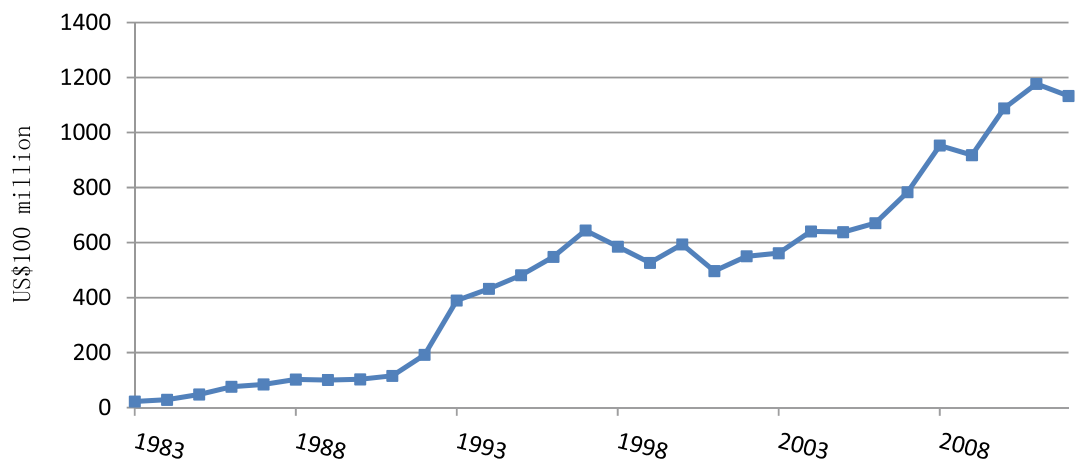

Fig. 11 1983-2012 China's actual use of foreign capital (Data source: Same as above)

China's tax favoritism policy helped foreign investors lower business costs, thereby increasing their competitiveness to access a wider market. ${ }^{24}$

This round of investments since 2001 were primarily concentrated on IT related manufacturing. Driven by internet development, IT industry production was gradually modeled by standardization and modularization. Developed countries and economies would therefore often transfer equipment manufacturing to China.

A noteworthy change was that FDI to China's tertiary sector as a proportion of total FDI went from 24.74 to $41.72 \%$ during 20052008 , increased by 16.98 percentage points in a short span of 3 years. At the same time, the proportion of secondary industry FDI declined from $74.07 \%$ to $56.66 \%$, a drop of 17.41 percentage points. By the end of 2008, China's actual use of FDI in the primary, secondary and tertiary industries as proportion of total foreign investment were $1.29 \%$ : 56.66\%: 41.72\% (Peng and Liang 2010).

Under the wave of global industrial transfer and reconfiguration of industrial value chain, China's opening up underwent a change in its mechanism, with devaluation of domestic currency and endeavors of

\footnotetext{
${ }^{24}$ Peng Tong (彭曈) \& Liang Shuang (梁爽), “外商直接投资在三次产业中的分布及评价 (Distribution and Evaluation of Foreign Direct Investments Among Tertiary Industries),' China Venture Capital, 2010(4): 47-50; Li Wenjing (李文晶), ‘中国FDI与经济增长的产业分析 (Industrial Analysis of China’s FDI and Economic Growth),' http://ems.nwu.edu.cn/economic/ 26/lianjie/papers/3.htm.
} 
local governments to attract foreign capital. At real economy level, the impetus for China to join international trade changed from domestic overcapacity to external demand. With regard to the financial system, China actively took part into the new international economic circulation dominated by financial capital of the core countries with U.S.A. in the lead, which meant the emergence of China's "financial dependence" on overseas market, as stated by Wang Jian in earlier section.

\section{Structural Contradiction in China's Economy-Three Overcapacities and Worsening Imbalance of the Troika}

The surge of China's economy since 2003 was in synch with the blooming cycle of international economy. From 2003 to 2007, China’s GDP sustained high growth rates at double digit for 5 consecutive years. By 2007 it reached the peak of $13 \%$.

Justin Lin Yifu pointed out in 1999 that a vicious cycle under the condition of "double overcapacity" had emerged in China's macroeconomic operation. What he was referring to at the time was excess labor force and excess general manufacturing capacity. Adding the excess in financial capital that emerged after the financial reform was completed at the turn of the century, there would be three major overcapacities. Following China's deepening participation in global economic regime, the structural contradiction of these three overcapacities was further reinforced during the economic surge.

Excess labor force had been a problem China was faced with since the modern era, even though in the course of industrialization over a century, a large number of excess rural population had already been relocated to cities and China's urbanization rate had reached $46 \%$ in 2008 (this data was based on the newly revised definition of urban population in statistical sense). The academic community was generally skeptical about the extent of urbanization. There were still around 130 to 200 million excess labor force in rural regions (Nie Minghua \& Yang Feihu 2010). With regard to excess capital, structural imbalance appeared in the consumption market in early and mid-1990s with 
insufficient consumption power among low-income groups and underdevelopment of high-end consumption markets. Moreover, domestic saving rate also went up significantly. Since 1994 the banking system began to record positive deposit differential. By the third quarter of 2007 the deposit differential in financial institutions had reached 1251.97 billion yuan. The loan to deposit ratio was $69.5 \%$. That was an indication of worsening problem of excess financial capital. Regarding general manufacturing capacity, spurred on by proactive fiscal policies, a sudden increase of supply worsened the problem of overcapacity that had already emerged by the end of 1990s. This sudden expansion was due to the completion of a large number of heavy industry projects and being put into production from the second half of 2002 to first half of 2007.

In company with the worsening situation of three major overcapacities, the imbalance of the Troika, the "three-horse carriage" (investment, consumption and export) also deteriorated.

Domestic consumption should have been the main impetus of economic growth. However it had long been depressed in China since mid-1990s. In general, it was regarded as a problem of weak consumption power. With almost unlimited supply of labor in absolute excess, general labor wage was suppressed over a long run. In particular, an enormous number of peasant households relying on cash income had very low purchasing power, resulting at general under consumption. Furthermore, the widening income gap between the rich and the poor made under consumption even worse. Oversupply of manufactured goods had to be digested by export, in turn boosting the trade surplus. ${ }^{25}$

Since mid-1990s, China was consciously or semi-unconsciously oriented towards globalization and continued to be integrated into the mainstream global economic trend. Alongside insufficient domestic demand, investments and external demands were growing robustly. Since early twenty-first century, monopolistic financial capital in excess began to alienating itself from industrial capital, integrating mainly with real estate sector and stock market, which in turn spurred on the rapid development of real estate, funds, stocks and futures trades. That was also

${ }^{25}$ Wang Jian, ‘防过热更需防过剩 (Caution on Overheat and More Importantly Overcapacity)’, 中国经贸导刊 (China Economic \& Trade Herald), 2007(17). 
the regular trend with which western core countries or core sectors had maintained economic growth. As for local governments, given that fiscal and financial means were monopolized by the central government, they could only rely on more debt-driven investment through land financing, following the path dependence of "high investment + high indebtedness = high growth" model.

External demand contributed a higher and higher proportion to China's economic growth. China's general domestic overcapacity and under-consumption was complementary with the expanding overseas demand as international industrial capital shifting to the emerging industrial state. As a result, China's national economy became over dependent on the export sector. China's trade dependence ratio (import + export)/GDP) had reached $66 \%$ in 2006. In comparison, the ratios of the U.S.A., Japan, India and Germany remained stable at 14-20\% level from the 1980s to 2001 (Shen Jiru 2004). Even taking into consideration differences in calculation specifications, China's dependence on trade was still much higher than the developed countries and large developing countries in comparison. The overcapacity in basic industries could only be dealt with by means of "overdrawing tomorrow's overcapacity to digest today's capacity". ${ }^{26}$

Under such a structural imbalance, China's economy actually proceeded at a fast but extremely uncoordinated pace, with two "wild horses" (investment and export) pulling a "lean donkey" (domestic consumption).

\section{Corporatized Local Governments "Cashing in Land": The "High Investment + High Indebtedness = High Growth" Model Led by Urbanization}

China's endeavor to attract business as well as capital, and the supply of capital that arose in excess international industrial capital's pursuits of factor price valley, were in fact the two facets of the same process.

\footnotetext{
${ }^{26}$ Lang Xianping (郎咸平), “美国正把中国复制成第二个日本 (The USA Is Turning China into a Replica of Japan)’, 中国物流与采购 (China Logistics and Purchasing), 2010(12).
} 
The formation of the investment-driven model to growth was related to the centralization of fiscal power by the central government amidst the fiscal crisis in 1993-1994 and financial power amidst the crisis in 1997-1998.

In the 1980s, the capitalization of factors such as finance, land and labor had been conducted at the local level. The first two were by nature local whereas the third (labor) was not free to migrate back then. With the bloom of rural enterprises, localized industrial development had taken shape and the gains from capitalizing the three essential resources were by and large kept within the sannong sector.

Yet from 1994 onward with the new Tax Division System, and in 1998 with comprehensive reform of the financial system, local governments' fiscal and financial powers were significantly weakened. Furthermore, as labor force was free to migrate (even if not migrating local governments no longer had the subjective and objective conditions to make use of a scale effect of labor to substitute capital in upgrading industrialization), the only remaining resource that local governments could mobilize in the name of the state was land. When the macroeconomic environment became favorable again, local governments took to capitalize land to promote high speed export-oriented development, attracting capital to their respective jurisdictions. And even if not trying to introduce foreign capital, many top local officers would appropriate land haphazardly for conspicuous constructions such as government buildings to create a track record of good political achievement by having brought in capital from banks.

However, such non-productive investments ended up as large-scale indebtedness for which local governments did not have to take the responsibility. And since the central government found it hard to bear that increasingly heavy debt obligation either, continuous expansion of money supply became the only available means.

We may take a look at how it worked.

Due to regulation constraint as well as high transaction costs in dealing with scattered peasants, prospective land users and even developers would not directly deal with the peasants who worked on the land. On one side, local governments would appropriate the land at a very low cost, made possible by their monopolistic authority. Then 
through various financing agents such as land reserve centers, urban investment companies, development zone management committees, etc., they would mortgage the land to banks to obtain loans for infrastructure constructions. By 2006, around $60 \%$ of investments worth tens of billions into infrastructure in counties and towns along the southeastern coast had been financed through land. In the western regions, funding through bank loans had even accounted for as much as $70-80 \%$ of urban infrastructure investments (Jiang Sheng San \& Liu Shouyin et el 2007)

On the other side, local governments accelerated urban expansion in order to increase the scale of various types of local taxations as well as revenues from land concession. By 2002 local business tax had rapidly risen to become the largest source of tax revenue for local governments. By 2006, the proportion of business tax out of total local taxation reached $43.3 \%$ (the next in line was profit tax at $18.1 \%$ ). The business tax was mainly levied on construction and tertiary industries. That motivation made it a pressing matter to expand urban regions, in turn the construction industry for increasing business tax revenue. A research by the World Bank pointed out that, driven by the motivation of increasing fiscal revenues, local governments enthusiasm towards land development, infrastructure investments and expanding the scale of local construction had been unprecedented since 2002 (World Bank Urbanization and Land System Reform Project Team 2005).

In a research report published during that same period, we referred to this process between local governments and banks as "cashing without land". We believe it suited financial capital's urge to integrate with the real estate sector after its alienation from general industries, as a result driving urban expansion. The first thing it pushed up was the windfall real estate profits, making it "the channel for local governments to repay the enormous loans for urban infrastructure investments as well as to realize revenues from land concession." Real estate became the realm into which excess capital jostled for entrance. Spurred on by infrastructure construction and real estate, related industries were blooming. Since 2002 , the proportion of fixed investments stayed at $60 \%$ of total new demand (Wang Jian 2006).

In this way, with the third round of land enclosure as the starting point whereby local government "cashing out land", the development model of 
"high investment + high indebtedness = high growth" founded on "high land closure" gradually took shape at the beginning of the new century. And since 2002 local government fiscal deficits were increasing rapidly. Furthermore, the excess financial capital at central level also added fuel to the speculative markets, which ushered China's rapid economic surge in the new millennium.

\section{How the "New Pro-People's Livelihood Policies", Represented by the Sannong Strategy, Facilitated the "Soft Landing" of 2008 Crisis}

\section{“Sannong New Deal”: Background and Contents}

In late 1990 s, because of the volatility in macro-economy the third crisis in rural governance had occurred. ${ }^{27}$ We believed that rural governance crisis was mainly the outcome of costs transfer towards underprivileged groups or sector by powerful agents maximizing their institutional gains during institutional transition. That would be pertinent to understanding the background for the introduction of the "Sannong New Deal”.

It is well known that in modern society agriculture has to face the double risk factors of market and nature. Consequently agriculture as compared to other modern industries would be more vulnerable. During the transition from traditional to so-called modern society, the sannong also has to face the third risk: the cost of institutional transition, an institutional risk in political-economic sense that arises due to the domination of powerful interest blocs over policy decisions.

Therefore, whether during economic crisis or rapid economic development in urban sector, fundamental factors in the sannong, scarce resources such as funds and land, saw outflows at an accelerated rate. And even rural funds would find it increasingly difficult to integrate with the factor of labor given the latter's seasonal migrations. Not only had it resulted in deterioration of rural economy, society and culture, it even

\footnotetext{
${ }^{27}$ See: Dong Xiaodan \& Wen Tiejun, “宏观经济波动与农村“治理危机” (Rural Governance Crisis and Macro-Economic Volatility)’, 管理世界 (Management World), 2008(9).
} 
exacerbated the third crisis of rural governance since 1997. The crisis was not alleviated even with the revival of the macro-economy although there had been a structural change since 2004 following the abolition of agricultural tax.

After China entered a period of high economic growth in 2003, rural labor once again flocked into cities in large numbers. Agricultural employment decreased from 365.46 million in 2003 to 306.54 million in 2008, which implied a decrement of hidden unemployment by 58.9 million people, as high as $16.12 \%$. However, employment opportunity did not necessarily lead to income growth. Following the emergence of export-oriented economy consisting mainly of processing manufacturing, Chinese factories and workers only shared the smallest portion of the total added value in the entire industrial chain. The wages for migrant workers were generally suppressed. In a research conducted by the Department of Labor Security that compared labor costs in manufacturing between China and 20 countries, it was found that average labor costs in developed countries generally accounted for around 35$50 \%$ of the added value, other country categories generally $20-35 \%$, while China's was only 9.3\%. Furthermore, according to related studies, minimum wages in many countries were generally at $40-60 \%$ of the average wages in the society. In China that percentage was notably low overall. In the Pearl River delta region the number was generally as low as $30 \% .^{28}$ And after these good quality workers were thus exploited in urban sector, their retirement and social security had to be borne by the home village. That meant not only did the rural regions not have enough labor force to support rural development, they had to bear a social burden. ${ }^{29}$

In the cyclical crises that took place before 1998 largely due to endogenous factors, rural regions had been the primary recipient of cost transfer from urban sector. By the two crises during 1998-2009 that arose mainly

28 中国农民工调研报告 (Survey Report on Chinese Migrant Workers), China Yan Shi Press, 2006, p 31 .

${ }^{29}$ For the concept of “multiple exploitation” see: Pan Zequan (潘泽泉), “全球化、世界工厂与 中国农民工发展的经验教训 (Lessons from Globalization, World Factory and China’s Migrant Worker Development)', Guangzhou Social Science, 2008(1). 
due to exogenous factors, China had already entered the phase of industrial overcapacity. Upon "farewell to shortage," the government's policies in response were obviously different from earlier occasions. The key manifestations were stronger macro coordination and rebalance on three major gaps: rural and urban, the east and the west, as well as the rich and the poor. Nevertheless, on one side the institutional costs of 'government retreat' from the urban economy in the 1990s could not possibly be offset in a short span. On the other side, given the diversity of local regions they were indeed hard put to accept the central coordination. The only realm that could most embody the central government's "Peopleoriented Scientific Development" concept and "People's Livelihood New Deal" was the sannong, to which the local interest groups had already become indifferent.

A year before putting forward the notion of "people-orientation" as the premise for development in 1999, the CPC had taken the opportunity of the 20th anniversary of Household Responsibility Contract System to pass the Central Bureau's decision on 'Certain Important Issues Regarding Agriculture and Rural Regions' in the third plenary of the 15th Congress. The direction was to "steadfastly execute the extension of the land contracting period for another 30 years, and at the same time take initiation in setting laws and regulations to ensure long term stability of the land contracting system, granting to peasants the land usage right with protection on an on-going basis." It would go down in history as the second round of household land contracting with an even land re-allotment in accordance with the population in village, established as the basic economic institution in Rural China.

Under this context, when the 16th Congress of the CPC put forward the major target of "building a moderately prosperous society in all aspects", President $\mathrm{Hu}$ Jintao pointed out clearly in the report that to achieve the goal the focus and the difficulty would both be in the rural regions. He later stated again that future sannong policies should place priority on giving peasants tangible benefits. Later, in the rural working meeting convened by the party central committee in January 2003, President Hu emphasized again that "the sannong issue is the most important of all important party work", to counter against the situation in which 
relevant departments lagged in following the central strategic adjustments. Over the next 5 years, the central government reiterated twice every year that theme of "the sannong being the most important of all important issues", first in the CPC plenary meeting as well as the People's Congress and then in the Political Consultative Conference. During those years, President $\mathrm{Hu}$ also made the important assessment of "two stages and two nurturing". [In the past agriculture supported industry. Now industry should nurture agriculture]. In the fourth plenary meeting of the CPC 16th Congress in 2004, he gave the directive for resolving sannong issues, setting the keynote to shape the mechanism of industries nurturing agriculture as well as cities supporting the rural under new circumstance. To mobilize peasants' pro-activeness in producing grain crops, China began to allocate a portion of the subsidies previously dedicated to the circulation regime to directly subsidy the peasants cultivating grain crops.

In the CPC 17th Congress in October 2007, the theme "sannong being the most important of all important issues" was adopted as a guiding principle of the $\mathrm{CPC}$, and reiterated with emphasis in the political report for the Congress in an unprecedented manner.

While that proposition had been stressed on continuously, in September 2005 the Central Political Bureau put forward the opinion that China's 11th 5-year plan must comprehensively follow through with the 'scientific development view' and the strategy of "building socialist new countryside". Afterwards, the fifth plenary session of the 16th Congress convened by the CPC Central Committee in October officially established "building the socialist new countryside" as the topmost strategy in a list of eight.

The 19th meeting of the 10th Standing Committee of the People's National Congress passed the resolution on the 29th December 2005 to repeal the "Agricultural Tax Law" on January 1, 2006. That meant the agricultural tax that had existed in China continuously for over 2000 years officially became a bygone in history.

The 2006 CPC Central Committee Document No. 1 gave concrete policy requirements in building the socialist new countryside, supplemented by concrete measures on financial transfers and payments as well as 'industries nurturing agriculture' (Table 6 and Image 1). 
Table 6 Pro-peasants policies introduced since 2003

\begin{tabular}{cc}
\hline Year & New pro-peasants policies contents \\
\hline 2003 & $\begin{array}{c}\text { Supported the sannong. Rural taxation reform. Plan to establish new } \\
\text { rural cooperative medical system } \\
\text { Suggested abolish agricultural tax in } 5 \text { years. Introduced three types } \\
\text { of subsidies to rural regions } \\
\text { Certain provinces and urban regions abolished agricultural tax on } \\
\text { 'self-funded' basis } \\
\text { Total abolition of agricultural tax. Launched integrated agricultural } \\
\text { subsidy. Exempted rural regions in west China from tuition and fees } \\
\text { for education. Permitted three types of rural financing pilot scheme: } \\
\text { peasants mutual financing, micro finance and village township } \\
\text { banks } \\
\text { Free education in rural regions. Promoted New Rural Cooperative } \\
\text { Medical Insurance \& Rural Minimum Living Security. Promulgated } \\
\text { the Specialized Peasants Cooperatives Law } \\
\text { Increased integrated agricultural subsidy. Raised participation rate in } \\
\text { the New Rural Cooperative Medical Insurance. Comprehensive } \\
\text { exemption of all school fees and expenses. Revised new law on } \\
\text { obligatory education. 562.5 billion yuan of sannong budget, an } \\
\text { increase of 130.7 billion from previous year. Adopted ten important } \\
\text { measures to support agriculture and grain crop production } \\
\text { Implemented new rural pension insurance. Developed middle level } \\
\text { vocational education in rural regions and phasing in fee exemption. } \\
\text { Increased sannong budget. Eliminated obligatory financing to upper } \\
\text { tiers' investments of large agricultural counties. Expanded } \\
\text { agricultural financing and insurance pilot sites. Subsidies to peasants } \\
\text { in purchase of home appliances } \\
\text { 'Home appliances going to countryside': diverted to Chinese peasants } \\
\text { the 13\% export tax rebate which previously equaled to subsidies to } \\
\text { foreign consumers; Unsalable home appliances in export sector sold } \\
\text { to rural regions in large quantities, helping China to convert to } \\
\text { domestic demand driven growth in a short time }\end{array}$ \\
2009 \\
2010 .
\end{tabular}

Source: Based on the CPC Central Committee policies in recent years, Yang Shuai revised the table in a paper by Professor Wang Shaoguang of the Chinese University of Hong Kong at a conference in Sungkyunkwan University of Korea on 18 March 2007

\section{Repairing the Regulatory Function of Rural "Capital Pool" and "Labor Pool"}

At the same time as the central government began implementing new sannong policies, a whole series of pro-agriculture and peasants measures were introduced over a short span of time. On one side it gave rural sector the opportunity to recuperate, so that its regulatory function 


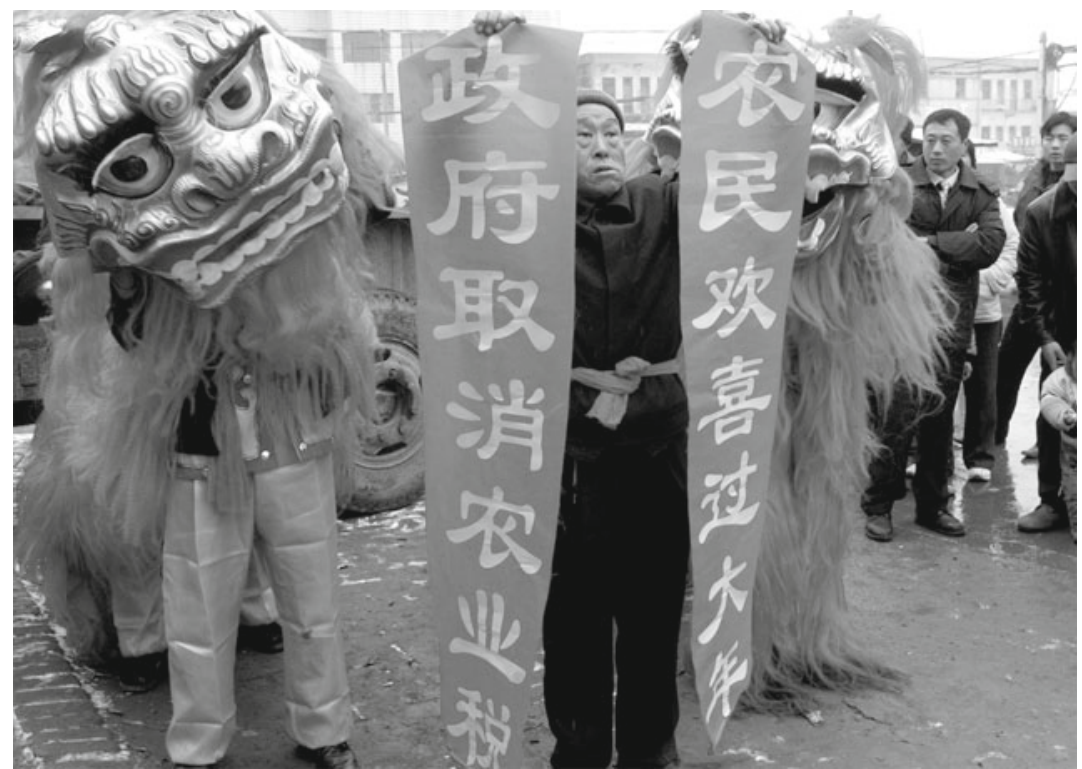

Image 1 On the 9th February 2005, the Hebei provincial government announced the total abolition of agricultural tax in Chinese Lunar New Year. On the New Year day, a peasant from Hebei province by the name of Li Zhongjie brought his lion dance team to the government building in his county and displayed a couplet on scrolls to express the peasants' heartfelt joy on the abolition

as a 'labor pool' could be repaired. On the other side, it strengthened the county economy's regulatory function as a second 'fund pool' beside urban sector. Undoubtedly it had a positive effect on rectifying the structural contradiction of 'three overcapacities' and the unbalanced 'three-horse carriage' in China's economic growth, thereby raising the on-going sustainability of China's economy and development.

The concrete transmission mechanism consisted of the following:

One: unprecedented amounts of investment enabled the sannong to absorb the excessive portion of capital and production capacity in the national economy. The investments in support of the sannong during 2003-2008 totaled more than 1.4731 trillion yuan at current 
year prices. ${ }^{30}$ Furthermore, based on estimation, the cumulated state sannong budget during 2003-2009 came to 3.097 trillion yuan, an average of 15,000 yuan per peasant household, and an annual average of 2500 yuan per capita. Not only did it increase the capital stock in the rural capital pool by a substantial volume, the infrastructure construction also provided large number of local non-agriculture employments, making it possible for the severely impaired regulatory function of rural labor pool to be partly mended.

Two: large amount of pro-sannong investments to a certain extent stimulated consumption demand in rural regions. Most of the policymakers in general agreed with the effect of new countryside construction in expanding domestic demand, with the view that rural sector was an enormous force driving domestic demand and promoted economic growth. According to a research by $\mathrm{Ma}$ Xiaohe et el, the marginal propensity on consumption for peasants was $75.3 \%$ during 2000-2004, compared with 69.5\% for urban residents. During 20002003 , the total annual increase in retail volume in consumption goods at county level and below was around 100 billion yuan. It more than doubled to 231.2 billion in 2004 . Then it increased by another 148 billion in the first seven months in 2005 . Some researchers estimated that the initiative of new countryside construction would give rise to a retail volume growth on consumer goods of more than 400 billion per year during the 11 th 5 -year plan period. The incremental contribution to GDP volume would be more than 2 percentage points. ${ }^{31}$

Third: With reversed flow of resources back to rural regions, wide spread confrontations between peasants and local grassroots governments, arising before out of economic tension, was alleviated and

\footnotetext{
${ }^{30}$ Based on data in China Statistical Yearbooks, investments from the central government covered agricultural support expenditure (including farming, forestry, irrigation, meteorology as well as integrated agricultural development), agricultural infrastructure expenditure, agricultural technology expenditure, rural relief funds, and so on. Due to data limitation, the figures for 2003-2006 included only agricultural support expenditures while figures for 2007 and 2008 included only farming, forestry and irrigation. Therefore actual total investments on agriculture and peasants should be more than 1.79 trillion yuan.

${ }^{31}$ Huang Wei (黄惠), “社会主义新农村——农村是拉动内需被忽视的动力 (Building the New Socialist Countryside-The Countryside Was the Neglected Impetus in Domestic Demand Stimulation)', 膫望 (Outlook), 2005-11-23. http://www.agri.gov.cn/jjps/t20051123_500588. htm.
} 
transformed into general disputes over money interest within rural communities. Stability in rural regions improved overall. That was the social foundation upon which the sannong could once again be relied on to bear the cost transfer of crisis.

All these were the fundamental conditions that afforded China's economy with the leeway to respond to the Wall Street financial crisis without sustaining damages.

\section{8-2009: China's Response After the Second Imported Crisis}

In face of the second imported crisis took place since merging into globalization, Chinese economy's sensitivity and vulnerability to external demand volatility were obvious. Fortunately, central government's enormous investments into the sannong before and during this period had laid down a rather smooth road for China's imbalanced, fast moving economic 'carriage'. It was on the solid base of the continuous investments into the sannong over consecutive years that China was conferred with the conditions of making a 'soft landing' in the crisis.

\section{The Global Financial Crisis and Its Impact on China}

On 15 September 2008, the news that Lehmann Brothers, the fourth largest investment bank in the United States, officially declared bankruptcy while Merill Lynch was bought out by the Bank of America sent the global stock markets into violent crashes. Wall Street experienced the worst day since 911 with the Dow Jones Industrial Index falling by more than 500 points or $4.42 \%$. Some major European indices fell by more than $5 \%$ at one time. Financial stocks in Asian regions generally fell while the Taiwan Stock Exchange Weighted Index dropped by $4.1 \%$ to its lowest level in 3 years. In Russia, due to heavy losses in the stock market the government ordered a halt in trading in all exchanges on 17 September. Consequentially, US\$5.79 trillion of market value was evaporated in the month of October. After the crisis, within a short span of 
time there were 14 bank bankruptcies in the USA alone. Most major financial and securities markets around the world suffered heavy blows.

This crisis that erupted in the core zone of capitalist core sector unfolded in less than a month into a total economic crisis and spread to other developed economic bodies. On 23 October 2008, White House spokesperson Perino indicated that although the federal government had adopted bold measures to rescue financial institutions, economic growth in the U.S. would still be facing difficulty. The October economic report published by the Japanese government believed that Japan's economy was receding. The data announced by the U.K. government on 24 October indicated that the country experienced a GDP decline of $0.5 \%$ compared to previous month for the first time since 1992. The basic economic situation of the Euro zone also deteriorated at an accelerated rate. The extent to which manufacturing shriveled in Germany, France, Italy and Spain exceeded expectations.

The deterioration in the financial, economic and trading environments around the world gave rise to the challenges of shrinking trade and capital outflows in emerging countries, given their reliance on export expansion strategies for fast growth. China as the world's top exporting country also encountered drastic decline in exports, and in relation to that a serious domestic economic crisis emerged. China's seriously misbalanced economic structure was immediately under impact. On one side, it severely damaged the export economy relying on overseas demand. The export sector's contribution to GDP fell from 2.6\% in 2007 to $0.8 \%$ in 2008. Large scale layoff of migrant workers was remarkable in coastal regions specialized in export sector (see column below). On the other side, as international hot money swarmed into commodities markets after the Fed's Quantitative Easing, the price of primary products surged and serious exogenous (or "imported") inflation emerged. ${ }^{32}$ The PPI rose from 5.4\% in 2007 to $8.1 \%$ in April 2008, and the domestic CPI in 2008 saw a monthly high of $8.7 \%$. China's economy, with insufficient domestic demand and hence over-reliance on export and investment, was immediately impacted. In addition, the

\footnotetext{
${ }^{32}$ Wang Jian, '关注增长与通胀格局的转变点 (Pay Attention to the Turning Point of Growth and the Inflation)', 宏观经济管理 (Macro Economic Management), 2008 (8).
} 
macro regulation policies being implemented began to take effect. The GDP growth rate for 2008 declined to $9 \%$. Even though still at a relatively high level, it showed a depressing trend compared to previous years (Fig. 12).

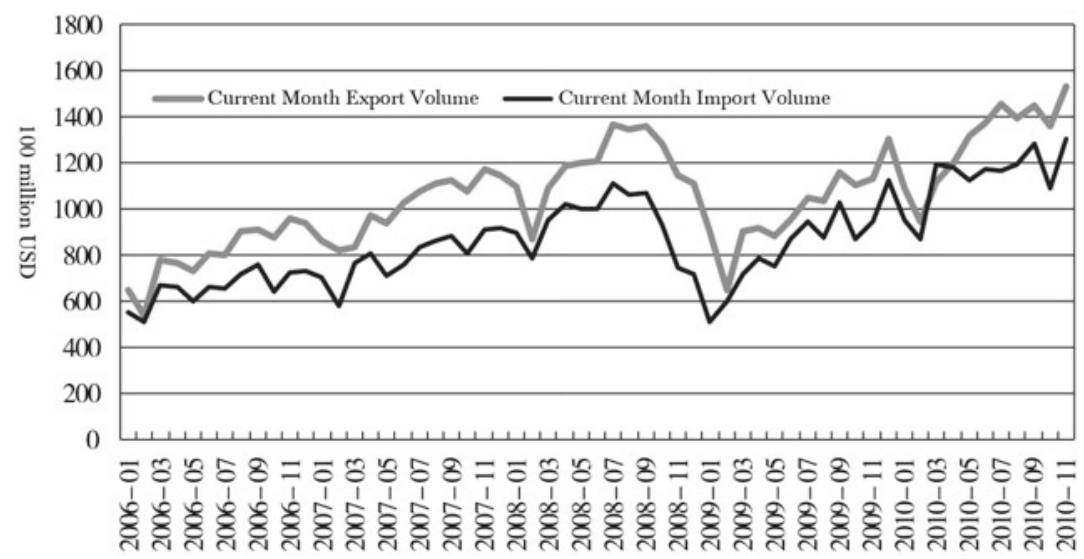

Fig. 12 Impact of 2008 financial crisis on China's export

\section{Box 9: Global Economic Crisis Causing Business Close-downs and Unemployment}

Based on information provided by relevant governmental departments, there were 25 million migrant workers being laid off in 2009, mostly due to wide spread business closing-down along the coastal regions with the onslaught of the global economic crisis. According to surveys, the number of small and medium size enterprises that had closed down in Guangdong during January to September 2008 came to 15,000, mainly in labor-intensive processing manufacturing including textile, clothing, electronic components, plastic, etc. Among the migrant workers who returned to home villages after layoff, $71.3 \%$ of them had worked in manufacturing and construction. 


\begin{tabular}{lll}
\hline & $\begin{array}{l}\text { Migrant workers } \\
\text { distribution \% }\end{array}$ & $\begin{array}{l}\text { \% Returning home } \\
\text { due to impact of } \\
\text { crisis }\end{array}$ \\
Jobs & 38.9 & 44.1 \\
\hline Manufacturing & 19.1 & 27.2 \\
Construction & 11.3 & 6.4 \\
$\begin{array}{l}\text { Domestic and other } \\
\quad \text { Services }\end{array}$ & 7.3 & 3.4 \\
$\begin{array}{l}\text { Accommodation \& } \\
\quad \text { Catering }\end{array}$ & & 1.9 \\
$\begin{array}{l}\text { Wholesale \& Retail } \\
\text { Transportation, } \\
\quad \text { Warehouse and }\end{array}$ & 6.7 & 3 \\
$\quad$ Postal & 5.4 & \\
Others & & 14 \\
\hline
\end{tabular}

Surveys by the Population Services Management Division of the National Population and Family Planning Commission also showed that majority of the migrant workers who returned home after layoff were previously concentrated in a few sectors - mainly in manufacturing and construction along the southeastern coastal regions, with geographically $49.2 \%$ in Guangdong, $15.3 \%$ in Zhejiang, $8.6 \%$ in Shanghai and $5.8 \%$ in Jiangsu. In terms of their urban employment structure, $55.7 \%$ were in manufacturing, $20.8 \%$ in construction, while the proportions in wholesale and retail, accommodation and catering were relatively small.

Source: Sheng Laiyun (2009); quoted from Cai Fang (2010).

\section{FDI and China's Financialization}

Foreign investments which had made significant contributions to China's pre-crisis wave of economic growth still showed a relatively large increase in 2008. ${ }^{33}$ Nevertheless that inflow was obviously blocked in 2009 due

\footnotetext{
${ }^{33}$ Before 2008, the regions around China were in competition with regard to attracting foreign direct investments. FDIs to China during 2006-2008 continued to grow. However, its weight in the world as a whole had ups and downs. The proportion had been falling from 2005 until 2008 when there was again a substantial rise. One major factor was that emerging countries such as Vietnam, Thailand and India begun competing for FDI, taking advantage of low labor costs and favorable policies. China by contrast had new factors such as the rapid rise in wages, improvements in labor protections, rise in land price and appreciation of the renminbi, which made China less attractive to foreign investments. During the financial crisis in 2008, the investment environment in China became relatively better in comparison. FDI that had flowed
} 


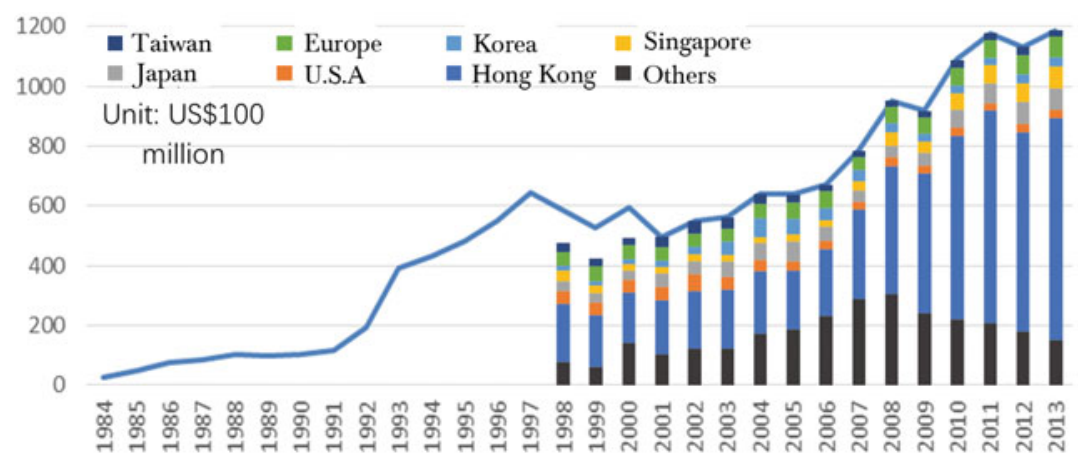

Fig. 13 1984-2013 total foreign investment actually used by China and sources (Source of capital-bars bottom to top: Others, Hong Kong, U.S.A., Japan, Singapore, Korea, Europe, Taiwan)

to repatriation of capital back to developed countries and showed notable fluctuations (Figs. 13 and 14).

It can be seen from the above graph that declining foreign capital and overseas demand resulted in a major decline of their impact on China's M2 supply, from the high of $60 \%$ in 2008 to less than $20 \%$ in 2009 . Simply looking at it from this perspective, the sudden drastic drop can unquestionably be defined as a round of "quantitative tightening' that had tangible effects.

The trend shown in the above graph not only represented China's accelerating financialization catalyzed by globalization since the 1990 s (indicated by the effect of increased money supply due to foreign investment inflows), it also showed that under globalization China's economic volatility showed cyclical patterns.

The Price of Joining WTO.

to other countries moved back to China. Year over year FDI movement in 2008 recorded a decline of $14.2 \%$ worldwide ( $29.2 \%$ in developed countries) and growth of $17.3 \%$ in developing countries, $29.7 \%$ for China, and $25.9 \%$ for economies in transition. Pu Changmo (朴昌模), ‘ 韩中外资政策的演变及其效应的比较研究 (Comparative Studies of Changes and Effects of Foreign Capital Policies between Korea and China)', Master Thesis, University of International Business and Economics, 2010; United Nations Conference on Trade and Development, World Investment Reports 2009 \& 2012. 


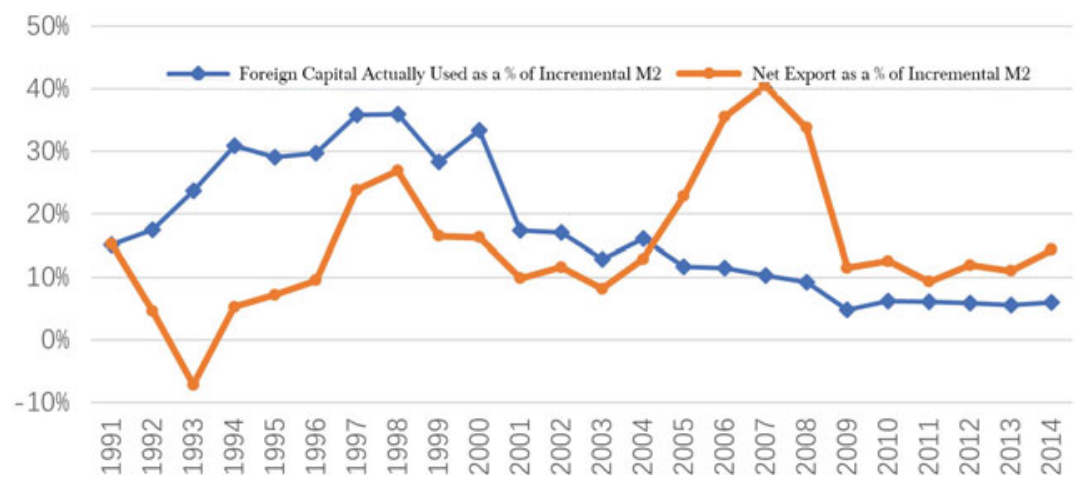

Fig. 14 1991-2014: Foreign capital inflow and attributable fraction on China's Monetary Issuance

In fact, even if there was not the Wall Street financial crisis, China's model of relying heavily on international market to achieve high speed growth would become increasingly difficult.

Based on the 2011 special report in Business Weekly 'Ten Years after Joining WTO,' China's export-oriented economy was facing several important constraining factors, such as anti-dumping investigations, intellectual property protection, vulnerable domestic industries being forced to face competition (see Box 10). Ten years after its accession to the WTO, China's export-oriented economy arrived at cross-roads.

\section{Box 10: China into WTO Ten Years Later: Brilliant Achievements, High Costs}

(1) Investigations on Anti-Dumping in Trade

Statistics from WTO's secretariat showed that in 2008 there were 208 anti-dumping investigations and 14 countervailing probes, with China being the target in 73 and 10 cases respectively, accounting for $35 \%$ and $71 \%$ of the total. China was the main focus of global antidumping investigations in 15 consecutive years, losing over US\$ 30 billion annually in relation to the investigations. In the year 2009 when the global economy was the most dismal with the onslaught of the financial crisis, China's export accounted for $9.6 \%$ of the global total, while 
anti-dumping disputes reached $40 \%$ of the total and countervailing cases reached $75 \%$. The number of trade investigations that China was subject to accounted for $43 \%$ of the worldwide total for the same period.

In a report published by the World Bank in March 2009, 17 out of the 20 countries having made the commitment of "guarding against trade protectionism" in the G20 financial summit in November 2008, introduced 47 protectionist measures less than 3 months after. Of these, many were targeted against China. For example, India prohibited the import of Chinese toys, while Argentina implemented non-automatic import licenses on textile, television, toys, leather goods, and so on. That report also pointed out that in the last few months of 2008, the number of anti-dumping and countervailing cases had a clear increase. For example, countries around the world in general gave subsidy to the automobile industry, with the total as high as around US\$ 4.8 billion, usually in high-income countries (accounted for US $\$ 4.27$ billion).

In February 2009, the new Obama administration passed the 'American Recovery and Reinvestment Act' totaling US\$ 787 billion, four months after the Bush administration announced rescue plans. The plan included terms of "buying American goods", requesting public construction and public projects supported by the stimulation funds to use American made steel, iron and manufactured products (with exemptions based on public interest considerations or when not available or costs not feasible). Besides, the Home Security Department should purchase only textiles and clothes made in America.

Under pressure from Europe, terms relating to buying only American products' were eventually revised. However the determination of U.S.A. to rebuild manufacturing did not change since that was considered by the Obama administration as an essential tactic for America's "economic rebalancing".

(2) Disputes over Intellectual Property Rights cutting into China's Export Gains

Entering the new century, China became the biggest producing and exporting country of DVD players. However the core technologies were entirely controlled by foreign enterprises. Chinese factories only conducted simple assembling. When the DVD players market and strength of China's companies rapidly grew, foreign patent holders in 
the realm organized alliances, including the 6C (constituted of Toshiba, Mitsubishi, Hitachi, JVC, Panasonic and Time Warner; later IBM also joined but it was still referred to as 6C), 3C (Philips, Sony and Pioneer; then LG joined to became 4C), 1C (Thompson) and several patent fee collection organizations like MPEG-LA (formed by 16 patent holders). They began to exercise their intellectual property rights. On 19 April 2002, China Audio Industry Association, after multiple negotiations over more than two years, finally reached an agreement with 6C stipulating that Chinese manufacturers would pay patent fee of US\$ 4 for each DVD player exported. Following that, similar agreements were signed with $3 \mathrm{C}$ at US\$ 5 for each DVD player, with $1 \mathrm{C}$ at $2 \%$ of selling price (minimum US\$2) and US\$ 1 for each Dolby equipment, with MPEGLA at US\$ 4 (adjusted to US\$ 2.5 in 2002) (Reference: 'Dispute over DVD Player Patent Fee,' Business Weekly, 5 November, 2005). However, the price of DVD players in the international market was consistently falling. By 2005 the retail price of DVD players on the U.S. market was only US\$30-40. Yet Chinese enterprises had to pay patent fees of totally US\$ 12 on each, leaving almost no profit. Quite a few companies had stopped producing or bankrupted.

Having been inspired by the DVD players case, foreign manufacturers also raised requests for patent fees on television, USB flash drives, CD, $\mathrm{CD}$ recording machines, digital cameras, motor cycles, and so on. In a 2004 research report by China's Science and Technology Development Research Center, the patent compensation payments on China's television export amounted to almost Renminbi 20 billion in 2002, accounting for $1.5 \%$ of total electronic equipment export or $30 \%$ of the profit on electronic equipment export. Since joining the WTO, the amount of compensation relating to intellectual property disputes had amounted to more than US\$ 1 billion.

(3) Entering International Market at the Cost of "Beheading" Domestic Industries

With the end of the WTO transition period in 2005, developed countries took a step further to request China open up the market.

In the post transition period, China introduced various market opening policies including limitations on agricultural subsidies, cancelling tariff quota on some import products, reducing import tariff 
year over year by a substantial extent or completely abolishing tariff. Furthermore, China promulgated in 2002 the "Interim Provisions on Restructuring State-owned Enterprises by Utilizing Foreign Capital", such that the introduction of foreign capital would have impact on "optimizing industrial structure and pushing state-owned enterprises ownership reform," in addition to the function of bringing in funds and technology, promoting economic development. Soon after, "beheading by foreign enterprise" (transnational companies acquiring and merging with leading Chinese enterprises) became a trend.

A report published by the State Council Research and Development Center in July 2006 mentioned that in China, out of the already opened industries, the top 5 companies in almost every industry were controlled by foreign capital. Out of 28 Chinese key industries, foreign capital had majority asset controlling right on 21 . Out of 18 state-level key home appliances enterprises, 11 were joint ventures with foreign capital. The cosmetic industry was controlled by 150 foreign enterprises and $20 \%$ of pharmaceutical enterprises were in the hands of foreign capital.

On 8 September 2006, to subdue the wave of 'beheading', China introduced the "Provisions on Merger and Acquisitions of Domestic Enterprises by Foreign Investors", tightening the loose approval process in the past.

In January 2011 Gary Locke, then U.S. Secretary of Commerce, expressed unconventionally ahead of President Hu Jintao's visit to the United States, that the trade policies and approaches that China executed over the past few decades would no longer be adequate in handling the bi-lateral trade relationship between the two countries in future. He said that the era of indebted consumption in developed countries was over and China should no longer rely on export.

Source: 商务周刊 (Business Weekly) Special Report 'Ten Years after Joining WTO'. http://finance.ifeng.com/news/20110321/371 1209.shtml.

The situations described above would indicate that if the Chinese did not have institutional and discursive rights in globalization then they could only be tamed sheep under the lead of the shepherds, no more than an "economic herd" in the globalized game. 
In its integration into the project of globalization on all fronts since the 1990s, China was continuously learning the lessons and gradually building up the ability to respond to challenges. Among them, the most effective measure was to replace external market demands with domestic demands. This experience has been one of the grounds upon which we emphasize on the theory of "resolving the risk of externalities by internalization". It was also the major competitive advantage that a large country with vast geographical width and depth had in particular to face the global competition.

\section{How Did Chinese Government Deal with the Crisis}

Generally speaking, the Chinese leaders executed with full confidence in dealing with the negative impact on economy by this global crisis and maneuvered the situation on a solid footing. Perhaps it was because China had already taken precautions through macro regulations and New Countryside Construction.

The central government's responses were still to focus on both aspects of domestic and external demands.

The similarity to the previous "imported" crisis was the proactive deployment of investments to drive domestic demands. The central government put forward in 2008 the decision to increase investments by 4 trillion yuan before the end of 2010 (of this, the central would provide for 1.18 trillion). In the 4th quarter of 2008 alone, new funds invested by the central government as well as the investments it stimulated from local and social sources came to totally 400 billion yuan.

The difference from the proactive fiscal policy in 1998 was the realm of investment deployment. In 1998 it was mainly on infrastructure construction. This time in 2008, out of the central government's new investments of 120 billion yuan, 10 billion was invested on security housing, 34 billion on rural livelihood projects and rural infrastructure constructions. Major infrastructure constructions such as railway, highways and airports accounted for 25 billion, development of social initiatives such as medical and health care, education, culture and so on 
13 billion, energy-saving and carbon emission cutting as well as ecological and environmental projects 12 billion, and support to innovation as well as industrial structure adjustments 6 billion. Furthermore, a 20 billion budget of 2009 for rehabilitation projects relating to the 2008 earthquake were paid in advance in the same year. It can be seen that this round of fiscal investments for countering the crisis not only mostly applied to livelihood projects, but also more than $1 / 3$ was devoted to the rural sector. Only 25 billion was used in infrastructure construction.

On external demand, the idea was generally similar to that in the previous crisis. However the policy support was even stronger. The key measure was to raise the export tax rebate rate to stimulate export under the condition of a stable exchange rate. From August 2008 to December 2009, the central government published 7 consecutive documents to raise export tax rebates on relevant goods, in an attempt to alleviate the blow on China's export oriented economy while demands in the international market shriveled.

\section{Function of the Rural Labor Reservoir in Stabilizing Society}

One notable difference of China's response to the crisis this time was its fore-sightedness: Premier Wen Jiabao had reminded in the summer of 2004 various officers around the country to guard against economic overheating and over-appropriation of arable land. At that time he already clearly put forward the idea of macro-regulation. In order to narrow the "3 major gaps", the central government began in 2005 to increase investments on strategic adjustments including projects like "Central China Rising" and "Building the New Countryside". That meant by the time overseas demand fell in 2008 due to the global financial crisis, Chinese leaders had already started three years before to increase substantially public debt-driven investments on domestic projects.

The central government's policy to increase investments in the central regions and rural sectors was originally a directive of the 11th 5-year plan, not intended as market rescue measures to alleviate economic downturns in face of crises, not to mention global financial crises. Nevertheless, it had in practice the effect of building the county-level economy as 
a 'second assets pool', effective in raising domestic demands, attracting excess domestic financial capital into investments, and absorbing larger number of inland rural labor to promote rural "townization". ${ }^{34}$

Although these measures had faced criticisms from many scholars who advocated radical capitalist reform, the consecutive years of large scale investments did indeed single-handedly bring about infrastructure improvement in central and western regions, as well as increase nonagricultural employment by tens of millions. The practical effect was that when the global economic crisis broke out, causing bankruptcies of many export oriented businesses in coastal regions and unemployment of more than 20 million of migrant workers. The landlocked regions were thereby able to absorb in time the labor force returning to home towns, alleviating the pressure on urban unemployment and social stability. For the new generation of migrant workers that did not have a plot of land to work on farming, the employment opportunity thus generated was particularly important.

According to Sheng et el (2009), it was estimated 64\% of those migrant workers who no longer returned to cities by the end of the first quarter of 2009 stayed locally to engage in agriculture. And after the 2009 Lunar New Year, the number rose to $67.6 \%$. $^{35}$

Therefore, we may conclude that China was able to achieve 'soft landing' with the sannong as the vehicle after the 2008 crisis only because of large-scale investments into the sannong beforehand and the propeasants policies continuously introduced. That was entirely different from the previous approach of simply dumping the costs of urban industrial capital crisis onto the sannong as it had happened repeatedly in the past half century.

Similar to the past, China had to pay a price to achieve the soft landing of this crisis. The most important negative impact was still that those inland and rural infrastructure constructions had to appropriate

\footnotetext{
${ }^{34} \mathrm{~A}$ mode of urbanization at appropriate scale at county level, integrated organically with the villages.

${ }^{35}$ Sheng Laiyun (盛来运), Wang Ran (王冉), Yan Fang (阎芳), “国际金融危机对农民工流 动就业的影响 (Impact of International Financial Crisis on Flow and Employment of Migrant Workers),' Chinese Rural Economy, 2009(9).
} 
large areas of land. The conflicts that ensued and the related institutional transition were still essentially a transfer of the institutional cost of industrialization and urbanization. The long term impact and how it may differ from before would have to be observed with time.

\section{Brief Comparison Between the Two Imported Crises Regarding Responses and Conditions}

Reflecting on the economic crises that took place in the past 3 decades since the start of reform in 1978, in particular comparing the crisis and the measures in the 1990s to this one, it could be seen that the situation in 2008-2009 was entirely different from that 30 years ago in 1979-1980 and 20 years ago in 1988-1989 while China was still in a stage of capital scarcity. Yet it had been highly similar to ten years ago in 1997-1998 when China had just entered the stage of excessive industrial capital. From the perspective of economic cycle, both imported crises coincided with the central government's macro-regulation to cool overheated economy.

The process down to the eve of 1997-1998 imported crisis could be summarized in general as follows. The economy had picked up speed after the stimulation by Deng Xiaoping's Southern inspection in 1992. It became over-heated in 1993-1994, with CPI as high as $24.1 \%$ in 1994, the highest in 30 years since the Reform. During the period there were three radical reforms - the merging of official and market foreign exchange rates, the tax division system reform and the state-owned enterprises reform that focused on headcount reduction to raise efficiency. These combined with a whole series of structural adjustment measure such as expanding fiscal deficit, expanding money supply, and liberating the securities as well as real estate markets. With these adjustments and measures to facilitate the reforms, the target of realizing "soft landing in 3 years" was eventually achieved in 1997. It was right at that point that China encountered the Southeast Asian financial crisis which led to substantial decline in overseas demands.

The process down to the 2008-2009 imported crisis could be summarized in general as follows. In December 2001 China joined the WTO, 
bringing in a large number of foreign companies. China completed financial market reforms in 2002. A new administration of central government took office in 2003. The third round of land enclosure by local governments then took place around the country. Over investment and over dependency on overseas markets emerged. These factors pushed in synchronization Chinese economic growth up to more than $11 \%$ annually. When over investment was worsening domestic industrial overcapacity, the 2007 Sub-prime crisis and 2008 Wall Street financial crisis hit hard the overseas demand on which China had become over dependent. Large numbers of businesses along the coastal regions went bankrupt giving rise to tens of millions of layoffs.

From the perspective of measures responding to the economic cycle, the fundamental condition for dealing with both imported crises was the institution of "whole-nation system": gathering force under central coordination to work on major tasks. In the summer of 1998 when there had been difficulties in adopting expansionary monetary policies, the central government made a timely switch to proactive fiscal policies through utilizing large-scale issuance of public debts to stimulate investments in infrastructures. Economic growth could thereby be sustained at the target level. When the crisis occurred in 2008, the early response had also been to take a loose financing policy. However it faced the same situation as the increased fund supply could not be effectively channeled to the real economy through lending. Then the measures were switched to public debt-driven investments.

From the perspective of effect, while the expansionary fiscal policy in 1998 had led to a substantial increase in the debt ratio (fiscal deficit/GDP) of the Chinese government, yet it did indeed improve to a large extent domestic infrastructure and build the "first asset pool" in major cities along the southeastern coast, thus providing the necessary condition for foreign direct investments marching in after being admitted into the WTO. It could be said that previous round of macroregulation of using public debt-driven investments to counter economic decline was proven effective by subsequent economic stability as well as the next round of high speed growth. And the measures adopted after the 2008 crisis were not short of mega infrastructure projects either. The important difference lay with the precautions taken three years prior to 
the crisis. The development of the county economy had built the second capital pool and the rural labor pool.

In terms of macro-economic context, China's economic development was situated in a different condition during the 2008-2009 crisis compared with ten years ago. In that earlier case the context was a generally rising market demand. The marketization reform, while being too radical and thus giving rise to enormous social costs, had been able to generate comprehensive institutional gains overall by focusing the whole nation's power to deal with the imported crisis. In comparison, the context in 2008 was declining demand. If the policy-makers still insisted on having recourse to market as the means to allocate economic factors, as ideologized by radical reformers as "new market economy", the government would often have to pay even higher institutional costs implementing strict macro regulation after market failure.

Moreover, few could have forecasted the emergence of an imported crisis. People's understanding of the 'cyclical economic crisis' could only develop on a gradual basis.

Put it concretely, the greatest difference between the two crises was that although the situation in 1998 was difficult and the following years 1999-2000 were a period of depression in accordance with economic law, the central government's strong push to a comprehensive "monetization of the economy" did indeed catalyze new demands, such as commercialization of housing and banking in 1998, as well as the industrialization of medical and education systems. These new demands all had the practical effect of absorbing large quantity of money, creating the fundamental condition for the government to increase money supply, rapidly driving the monetization of the economy. GDP growth was thereby pushed up. The total monetary volume was enlarged. The expanding government debts were therefore diluted and neutralized.

What came after were the general new demands generated by market structural changes, such as the booming demand for vehicles, housing, and related consumption. Following that, this type of structural upgrade in consumption gradually became an important impetus to China's economic growth since 1999.

The 1990s was a special era in which Chinese government adopted radical reform to abdicate its obligation of public goods provisions. That 
had generated a surge of booming demands which neutralized the greatly expanded money supply as a way for the government to deal with fiscal problem. Into the twenty-first century, that condition became a historical bygone.

In the new century China had completed the total monetization of the economy. Furthermore, domestic financial capital was already in a state of relative excess. The impetus of investments and overseas demands both became spent forces. Furthermore, the institutional gains from the central government's effective, rapid monetization and capitalization during the 1997-1998 crisis were already mostly eaten up by interest groups, while the institutional costs continued to accumulate without being resolved, hence often manifested as social conflicts.

Besides, the comprehensive marketization in mid and late 1990s could still be endorsed to some extent by the central government's authority. Fiscal and financial sectors were still functioning complementarily like the two pockets of the government executing macro-regulation. By that time, state owned financial sector had not yet become an independent capital force, alienated from industrial capital, in pursuit of higher liquidity for profit. Entering the new century, China's banking sector had completed commercialization mostly after the U.S. model. The allocation of funds needed for macro-regulation must be executed by a centralized regime. That inevitably resulted at a head-on collision with the commercialized financial sector which was largely motivated by profitseeking. Now the real economy was plagued by industrial overcapacity generated through a decade of high investment and high indebtedness. Unfortunately, the debt repayment cycle coincided with global recession. From the financial point of view, supporting the manufacturing sector by providing lending would end up with the accumulation of nonperforming debts and even an endogenous financial crisis. The interest of an independent, profit-seeking financial sector clashed naturally with the state's obligation to regulate the economy for the optimal benefits of the society as a whole.

In summary, the complicated situation China faced was a result of the procrastination to resolve the enormous indebtedness accumulated through decades of "high investment, high indebtedness, high growth" model. 
Finally, we must not neglect the international factors. China was long troubled by exogenous inflation since the 2008 crisis. It was because China, being the largest industrial country in the world, relied heavily on importing raw materials. However, the international primary commodities markets were flooded by hot money generated by the US Fed's Quantitative Easing as a way to save US financial system from crumbling. In a word, the USA transferred the cost of its crisis to other countries around the world, especially those developing countries relying on primary commodities from international markets. We were in a strange world where the USA practically recorded deflation after monstrous expansion of money supply and its M1 was even lower than its M0 after 2008. It was because the inflation was being transferred to the other parts of the world along with the flooding of hot money.

That was the root of the stagflation plaguing China, characterized by inflation and overcapacity. As what China faced was an "imported" or exogenous crisis, it would be hard to resolve by domestic policies alone. If China failed to partake in setting the rules of international institutions, these domestic policies would be very costly to be truly effective. 
Open Access This chapter is licensed under the terms of the Creative Commons Attribution-NonCommercial-NoDerivatives 4.0 International License (http://creativecommons.org/licenses/by-nc-nd/4.0/), which permits any noncommercial use, sharing, distribution and reproduction in any medium or format, as long as you give appropriate credit to the original author(s) and the source, provide a link to the Creative Commons license and indicate if you modified the licensed material. You do not have permission under this license to share adapted material derived from this chapter or parts of it.

The images or other third party material in this chapter are included in the chapter's Creative Commons license, unless indicated otherwise in a credit line to the material. If material is not included in the chapter's Creative Commons license and your intended use is not permitted by statutory regulation or exceeds the permitted use, you will need to obtain permission directly from the copyright holder. 